\title{
Columbia Law School
}

Public Law \& Legal Theory Working Paper Group

Paper Number 10-251

Intimate Discrimination: The State's Role in the Accidents of Sex and Love

Elizabeth F. Emens

Columbia Law School

Published

122 Harv. L. Rev. 1307 (2009) 


\title{
ARTICLES \\ INTIMATE DISCRIMINATION: THE STATE'S ROLE IN THE ACCIDENTS OF SEX AND LOVE
}

\author{
Elizabeth F. Emens
}

\section{TABLE OF CONTENTS}

\begin{tabular}{|c|c|}
\hline & \\
\hline 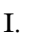 & THREE NORMS INSCRIBED IN LAW AND CUlTURE. \\
\hline & 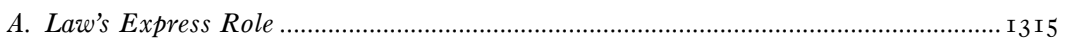 \\
\hline & B. Homogamy: Race....... \\
\hline & C. Desexualization: Disability... \\
\hline & D. Heterogamy: Sex..... \\
\hline & E. Intimate Norms Beyond the Intimate Sphere.. \\
\hline II. & ON INDIVIDUAL DIFFERENTIATION.. \\
\hline & A. The Individual Lover's Discourse... \\
\hline & 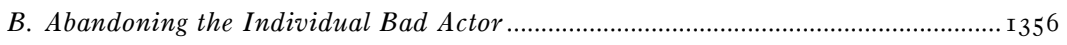 \\
\hline & C. Functionalism As an Individual Ethical Inquiry.... \\
\hline II. & ON STRUCTURAL DISCRIMINATION .... \\
\hline & A. The State's Role: Of Accidents and Calculations.... \\
\hline & B. Why Intimate Discrimination Matters..... \\
\hline IV. & The Roles the State Should Play....... \\
\hline & A. What Not To Do: Preliminary Ideas, Mostly Ill-Advised .............................. 382 \\
\hline & B. Toolkit: A Range of Plausible Structural Interventions ..................................... 1385 \\
\hline & C. Sex: Lifting Explicit Restrictions and Eliminating Penalties ............................ 1388 \\
\hline & D. Disability: Removing Barriers to Entry and Encouraging Intimacy .................... 1390 \\
\hline & E. Race: Unburdening Existing Relationships.......... \\
\hline & USION . \\
\hline
\end{tabular}




\title{
INTIMATE DISCRIMINATION: THE STATE'S ROLE IN THE ACCIDENTS OF SEX AND LOVE
}

\author{
Elizabeth F. Emens*
}

\begin{abstract}
This is a challenging moment for the law of discrimination. The state's role in discrimination has largely shifted from requiring discrimination - through official policies such as segregation - to prohibiting discrimination - through federal laws covering areas such as employment, housing, education, and public accommodations. Yet the problem of discrimination persists, often in forms that are hard to regulate or even to recognize.
\end{abstract}

At this challenging moment, the intimate domain presents a vital terrain for study in two main ways. First, conceptually, studying the intimate domain permits new insights into discrimination and the law's identity categories, because people are more willing to be explicit about identity-based preferences in this domain than in others (such as employment). Second, practically, examining the intimate domain reveals the ways that relationships in this sphere affect hierarchies and opportunities in more public domains, and the role the state plays in those relationships.

This Article therefore examines intimate discrimination, focusing on race, sex, and disability, and identifies key norms for each category. For race, the norm is homogamy, or pairing with one's own type; for sex, by contrast, the norm is heterogamy, pairing outside one's type; and for disability, the norm is desexualization, rather than pairing with one group or another. The Article does not assume that intimate discrimination is necessarily bad. On the contrary, examining the nuanced landscape of discrimination in this realm is one of the Article's main purposes. Ultimately, the Article concludes that,

* Associate Professor of Law, Columbia Law School. I thank the following people for comments on earlier drafts and helpful conversations: Jill Anderson, Susan Appleton, Adrienne Asch, Katharine Bartlett, Noa Ben-Asher, Christina Duffy Burnett, Mary Anne Case, Deborah Denno, Ariela Dubler, Richard Emens, Cynthia Epstein, Robert Ferguson, Peter Fraenkel, Katherine Franke, Phillip Atiba Goff, Alix Keast, Suzanne Goldberg, Victor Goldberg, Scott Hemphill, Adam Hickey, Clare Huntington, Olatunde Johnson, Rachel Jones, Sarah Lawsky, Robin Lenhardt, Daniel Malone, Martha Minow, Eben Moglen, Henry Monaghan, Rachel Moran, Martha Nussbaum, Brett Phillips, Robert Pollak, Alex Raskolnikov, Michael Rembis, Russell Robinson, Jennifer Rothman, Elizabeth Scott, Reva Siegel, William Simon, Rachel Smith, Richard Squire, Michael Ashley Stein, Geoffrey Stone, Lior Strahilevitz, Peter Strauss, Susan Sturm, Cass Sunstein, Bela Walker, Dorian Warren, Kenji Yoshino, and participants in the Regulating Family, Sex, and Gender Workshop at the University of Chicago Law School, the Work, Family, and Policy Workshop at Washington University, the Symposium on Unconscious Discrimination Twenty Years Later at the University of Connecticut School of Law, the New Frontiers of Family Law Conference at the University of Utah, the Critical Legal Conference at Birkbeck College, University of London, the NYC-Area Sexuality and Gender Law Workshop, the New York City Junior Faculty Colloquium at Fordham Law School, the Women \& Society Conference at Marist College, the Society for Disability Studies Conference, and faculty workshops at Columbia Law School and Loyola Law School. Christine Chang, Roberto Concepcion, Leah Godesky, Melissa Hazell, Maeve Herbert, Matthew Knox, Jacob Meyer, Meredith Morgan, Bradley Mullins, J. Andrew Pratt, Meera Shah, Chava Spivak-Birndorf, Becca von Behren, and Steven Wu provided excellent research assistance, as did the staff of the Arthur W. Diamond Law Library at Columbia Law School, especially Carissa Vogel and Beth Williams. 
at the level of individual interaction, intimate differentiation based on these identity traits can be good, bad, or neutral, depending on context. For this and other reasons, legal regulation targeting individual differentiation on these bases would be woefully misguided.

Nonetheless, the state plays important roles in intimate discrimination at a structural level. By creating the infrastructure of society, the state shapes the accidents of who meets whom and how. In addition, the state plays a role in the hierarchy of intimate opportunities by shaping social capital and relative advantages. The state therefore should reform its laws and policies to attend to its structural role in intimate discrimination. For sex, the most obvious next step is to cease to restrict marriage according to sex. For disability, the state should help to encourage opportunities for intimate affiliation by, among other things, attending to the architecture of intimacy, by which I mean the ways that structures of accommodation operate to help or hinder not only access, but also closeness. For race, the state's goal should not be to encourage race mixing, but rather to lift burdens on existing relationships, such as residential segregation. Recognizing how intimate affiliations affect opportunities and status hierarchies, both in the intimate sphere and beyond, points us toward new ways to intervene in the persistent problem of discrimination.

\section{INTRODUCTION}

There is a separation, as it were, between the bedroom and the boardroom. You don't want the government or its laws meddling in your private life, what you do behind closed doors is your own personal matter, etc. But, of course, this does not mean that there isn't a relationship between whom I desire and whom I hire, or between whom I want my children to desire and whom I hire.

— David Mura ${ }^{1}$

$\mathrm{T}_{1}$

he problem of combating discrimination faces a difficult juncture. Law has largely shifted from permitting or requiring discrimination (think segregated schools) to prohibiting discrimination (think employment discrimination law). At the same time, law has pushed discrimination underground. Most institutional decisionmakers - public and private - no longer say overtly discriminatory things. Discrimination is therefore harder to find and to regulate, because it has become less acceptable, legally and socially, to speak its language. Yet some groups in our society, such as people of color and disabled people, are still subject to systematic disadvantage. As many scholars have noted, this combination presents a difficult challenge for law and policies that address discrimination.

This challenge requires us to look into less obvious domains to understand the phenomenon of discrimination and to evaluate the proper

\footnotetext{
1 David Mura, The Internment of Desire, in Under Western Eyes: Personal Essays
} FROM ASIAN AMERICA 259, 282 (Garrett Hongo ed., I995). 
role of the state in its elimination. One such domain is the intimate. Because we do not police the intimate domain for discrimination, people are more explicit here about the distinctions they draw along lines of race, disability, and sex. By looking at our attitudes toward race, disability, and sex in the intimate realm, we can therefore learn about the condition and contours of our attitudes toward these categories more generally.

Intimate discrimination also has practical significance. As David Mura elegantly portrays in the epigraph, to speak of intimacy and discrimination together is to join two spheres that we tend to, and like to, consider distinct. Yet the intimate realm is central to our lives; families and other close relationships structure our communities and our selves. Intimacy is considered by many to be a valuable social good, so exclusion from intimacy has welfare consequences. Moreover, intimate affiliations and norms in turn affect our interactions in other domains, such as employment, as Mura suggests. Marriages involve not only private sharing, but also public networking. The intimate is thus a vital area for study as we confront the challenge of understanding and eliminating discrimination.

Discrimination in intimate relationships can of course occur along many axes, from class to geography to religion to age to musicality. This project is focused on a particular subset of those categories that constitute legally protected classifications when the domain shifts from the bedroom to the workplace: disability and race, and, to a lesser extent, sex and gender. ${ }^{2}$

Even if one accepts that people discriminate in their intimate relationships, one might wonder what this sort of discrimination has to do with law. In a way, our intimate exclusions might be understood simply as a form of discrimination that the law does not recognize. Unlike prospective employees, prospective lovers cannot sue if you refuse them based on race or sex or disability. We might conclude that there is nothing unusual about law's nonintervention in intimate discrimination - in this discrimination in contact, rather than in contract, to use Glenn Loury's terms. ${ }^{3}$ Perhaps intimate discrimination simply involves a private domain with no connection to law.

2 The Article uses the terms sex and gender to denote biology (maleness and femaleness) and culture (masculinity and femininity) respectively, in keeping with most scholarship in this area, even though they may not be so separable in practice. Sex, rather confusingly, also refers to sexual activity; I therefore try to make clear which I mean when.

3 Contrasting it with "discrimination in contract," Loury says that "discrimination in contact' refers to the unequal treatment of persons on the basis of race in the associations and relationships that are formed among individuals in social life, including the choice of social intimates, neighbors, friends, heroes, and villains. It involves discrimination in the informal, private spheres of life." Glenn C. LOURy, The AnATOMy of RACIAL INEQUALiTy 95-96 (2002) (footnote omitted). 
Yet law goes further than not permitting suits for intimate discrimination: law sometimes actually requires intimate discrimination. In addition to the most obvious historical example - antimiscegenation laws - the law has required intimate discrimination with regard to sex and disability. Moreover, even aside from its express requirements, law shapes whom we meet and how. It determines the accidents of sex and love, because it controls the infrastructure of our lives - our neighborhoods, schools, workplaces, public spaces, and more in ways that affect affiliations along the lines of race, disability, and sex. The state also affects rational calculations in the dating market through social policies that contribute to social hierarchies and wealth distribution.

Does this mean the state should treat intimate discrimination the same way it treats employment discrimination? The issue will be discussed in greater depth in the Article, but the short answer is no. Intimate discrimination should remain a litigation-free zone. But this does not mean it should be, or could be, a law-free zone. On the contrary, law should take account of its role in intimate discrimination at a structural level and work to eliminate burdens and biases that currently shape who has access to intimate relationships and on what terms.

Studying intimate discrimination thus serves two purposes, one conceptual and one regulatory. Conceptually, this inquiry limns key categories for the antidiscrimination project - race, disability, and sex - to help us understand better what those categories mean and how they operate in our society. And practically, studying intimate discrimination allows us to make conscious choices about how our regulatory interventions affect the fact and significance of intimate discrimination. ${ }^{4}$

Before beginning, I should note that in this Article I use the term discrimination advisedly. To discriminate means, among other things, to differentiate. Beyond this neutral denotation, the term's connotations vary from the pejorative, in the sense of invidious stereotyping (discriminatory hiring policies), to the laudatory, in the sense of possessing taste or appreciation of quality (a discriminating palate). ${ }^{5}$ In this Article, I assume no negative connotation to the term "intimate

4 I know of no other work addressing discrimination in intimate relationships across the categories of disability, race, and sex. One excellent recent article discusses both race and sex in relation to discrimination in dating. See Russell K. Robinson, Structural Dimensions of Romantic Preferences, 76 FORDHAM L. REV. 2787 (2008) (studying gay dating websites and the connections between the stereotypes on the websites and the structural features of the broader society).

5 See, e.g., Frederick Schauer, Profiles, Probabilities, ANd Stereotypes (2003); Linda Hamilton Krieger, The Content of Our Categories: A Cognitive Bias Approach to Discrimination and Equal Employment Opportunity, 47 STAN. L. REV. I I6I (I995). 
discrimination"; rather, a key aim of the project is to understand whether any such connotation, negative or positive, is warranted. Moreover, as a term of art in the field of antidiscrimination law, "discrimination" refers both to differentiation at an individual level and to differential effects of structural features of institutions, both typically with a pejorative connotation. ${ }^{6}$ That is, in the language of doctrine, discrimination includes both disparate treatment and disparate impact. Similarly, the term discrimination in this Article encompasses both individual differentiation and structural impact. The Article will progress from examining individual differentiation and rejecting the idea of legal intervention targeting individual choice to focusing on systemic impact and crafting appropriate structural interventions.

By the term intimate, I mean to denote sexual, romantic, or marital relations. ${ }^{7}$ Leaving out friendship and other ostensibly nonsexual relations opens me to the critique that has been lodged against work that privileges erotic affiliation. ${ }^{8}$ But that critique, though powerful as a normative matter, also implicitly highlights, as a descriptive matter, the significant meaning law and culture attach to the erotic realm, as distinct from other realms; whether ascribed or inherent, this distinction is undoubtedly a meaningful one in present day and time. Thus, discrimination means something different in the realm of erotic intimacy. In addition, marriage, dating, and sex are distinct, sometimes nonoverlapping, forms of intimacy; yet because identity-related norms of discrimination often traverse the boundaries between these intimate forms, I discuss them together, attending at times to points of departure among them.

A few caveats are in order. There are complicated subjects and types of intimate relations that this Article does not systematically address. Two in particular should be noted here. First, the question of capacity to consent in the context of mental disability raises important and difficult questions that this Article discusses only briefly - questions about the tension between autonomy and a right to sexual expression on the one hand, and concerns about coercion and abuse on

\footnotetext{
6 See sources cited infra notes 232, 432.

7 Intimacy is a far more complicated subject than my instrumental definition of intimate here allows. For instance, one can speak of sex or marriage without intimacy, and intimacy without a sexual component. For recent work elaborating some of intimacy's complexities, see, for example, INTIMACY (Lauren Berlant ed. 2000); LEO BERSANI \& ADAM PHILliPS, INTIMACIES (2008); and Elizabeth Bernstein, Temporarily Yours: Intimacy, AUthenticity, AND THE COMMERCE OF SEX (2007).

8 See, for example, Laura A. Rosenbury \& Jennifer E. Rothman, Beyond Intimacy 2 (Sept. 8, 2008) (unpublished manuscript, on file with the Harvard Law School Library); and Brenda Cossman, Beyond Marriage, in MARy Lyndon Shanley, Just MARriage 93 (Joshua Cohen \& Deborah Chasman eds., 2004).
} 
the other. ${ }^{9}$ Second, the Article generally does not discuss vertical, as opposed to horizontal, relationships. Adoption policy, for instance, raises intriguing and important issues at the intersection of discrimination and the intimate. Though I allude to the issues of race surrounding adoption, I do not purport to fold this difficult issue into an already expansive discussion of horizontal intimate relationships. Several scholars have written thoughtful accounts of the issue, and the extent of their disagreement helps to show the challenges it presents. ${ }^{10}$

Finally, this Article focuses on the categories of race, sex, and disability, rather than other categories, many of which are surely important to intimate decisions. This selection is not meant to imply that these three categories are necessarily the most important axes of intimate decisionmaking. ${ }^{11}$ Rather, these categories are the Article's focus because they are salient in antidiscrimination law and they provide rich material for considering discrimination in the intimate sphere relative to one another. Race is arguably our primary category of antidiscrimination analysis under U.S. law, making it important in its own right and as a comparator for other categories. By contrast, disability has been relatively understudied in antidiscrimination law and theory. The role of sex in our intimate choices is more obvious, and the state's ongoing role in regulating these choices is also more obvious, so I say less about it. But sex serves a useful conversation-forcing function,

9 I discuss the problem of abuse as it relates to the norm of desexualization and the need for legal reform, see infra section IV.D.I, p. I390, but for an in-depth discussion of these issues, readers should see, for example, Deborah W. Denno, Sexuality, Rape, and Mental Retardation, I997 U. Ill. L. Rev. 3i5; and Martha A. Field \& Valerie A. Sanchez, Equal Treatment FOR PEOPLE WiTH MENTAl RETARDATION (I999).

10 See, e.g., Elizabeth Bartholet, Nobody's Children: Abuse and Neglect, Foster Drift, AND the Adoption Alternative (I999); RANDAll KenNEDy, INTERRACIAL INTIMACIES 386-479 (2003); R. Richard Banks, The Color of Desire: Fulfilling Adoptive Parents' Racial Preferences Through Discriminatory State Action, Io7 YALE L.J. 875 (I998); Elizabeth Bartholet, Correspondence, Private Race Preferences in Family Formation, IO7 YALE L.J. 235 I (I998). In the context of disability, the topic of vertical relationships also raises important issues such as selective abortion - see, for example, Adrienne Asch, Why I Haven't Changed My Mind About Prenatal Diagnosis: Reflections and Refinements, in PRENATAL TESTING AND Disability Rights 234 (Erik Parens \& Adrienne Asch eds., 2000) - and the reproductive autonomy and decisionmaking of people with disabilities, especially mental disabilities — see, for example, FIELD \& SANCHEZ, supra note 9.

11 Were this an argument about the most significant determinants of intimate choices, there would be other key contenders, such as religion, class, and personal appearance. These other categories warrant further inquiry as they pertain to intimate choices, but do not feature prominently in this discussion of intimate discrimination as a lens through which to examine antidiscrimination laws and norms. Religion is commonly understood in this country, from constitutional rights to cultural values, as an affirmative basis for affiliation, in a way that distinguishes it from other categories. Class and personal appearance per se, by contrast, are hardly recognized by law, and so do not offer the same opportunities for thinking about the relation between the operation of the category in highly regulated domains such as employment and the relatively less regulated domain of the intimate. 
because it tends to frustrate the generalized assertion that desire in its ideal form would operate independently of "superficial" identity traits and instead would track something "deeper" in the self. Most people would, of course, not make the same assertion about the role of sex in their desire. And so including sex forces the recognition that some of these traits make a difference for many or most of us, and not necessarily in ways that are readily described as morally problematic. ${ }^{12}$

The Article has four Parts. The first Part describes how the law has expressly required intimate discrimination, then sets out three key norms that characterize our social regulation in this area: for race, homogamy (pairing with one's own group); for sex, heterogamy (pairing with the other); and for disability, desexualization (exclusion from the sexual realm). This Part concludes by discussing how these intimate norms affect the domain of employment and underpin problematic practices of employment discrimination. Part II maps the terrain of individual intimate discrimination, that is, of one person differentiating among prospective lovers on the basis of race, sex, or disability. The discussion considers the meanings that such differentiation can have, whether positive, negative, or neutral, and ultimately concludes that the state should not intervene in this realm at the individual level. Nonetheless, society would be better off if individuals engaged in an ethical self-interrogation about intimate discrimination, framed by the legal concept of functionalism, as explained herein.

Part III outlines the significance of intimate discrimination at a structural level and describes how law and policy create hierarchies of subordination both within the intimate realm and beyond it. Specifically, the state shapes who meets whom and how, and also frames the conditions within which individuals evaluate each other as prospective partners, whether for sex or for love. Thus, whether we think of love and relationships romantically or rationally, the state plays a meaningful role in our intimate lives, affecting our ostensibly autonomous choices as well as our social hierarchies. This Part concludes with a discussion of why intimate discrimination matters, including its effects on the problem of discrimination writ large.

Part IV outlines what role the state should play in intimate discrimination. After rejecting interventions that target individual decisions in the intimate realm, the discussion turns to key steps the state should take with regard to each identity category. For sex, the state's next steps are obvious: the state should not expressly regulate who can

\footnotetext{
12 But see IAN Ayres \& Jennifer Gerarda Brown, Straightforward: How To Mobilize HeterosexUAL SUPPORT FOR GAY RIGHTS 30-37 (2005) (arguing that discriminating on the basis of sex in one's dating choices is immoral, at least where it lacks an antisubordination purpose, and that it is akin to racial discrimination in dating). I return to Ayres and Brown's argument. See infra section II.B, pp. I356-57.
} 
marry whom on the basis of sex. For disability, the state should reduce barriers to entry to intimate relationships for people with disabilities, including reframing accessibility projects to take into account what I term the architecture of intimacy. And for race, legal interventions should lift burdens on existing interracial relationships, an approach that would challenge social policies relating to housing discrimination and residential segregation.

\section{THREE NORMS INSCRIBED IN LAW AND CUlTURE}

\section{A. Law's Express Role}

U.S. law has historically required rather than prohibited discrimination in the intimate realm - most obviously, by saying certain people cannot pair with certain other people. ${ }^{13}$ Antimiscegenation laws prevented sex and marriage across race in this country until, in McLaughlin v. Florida ${ }^{14}$ and Loving v. Virginia, ${ }^{15}$ the Supreme Court abruptly completed the gradual process of state-by-state elimination of such laws. In addition, until Lawrence v. Texas, ${ }^{16}$ laws prohibited, on their face or in differential prosecution, same-sex sex. ${ }^{17}$ Restrictions on who pairs with whom continue in the different-sex requirement of marriage under federal law and the laws of every state but Massachusetts and Connecticut. ${ }^{18}$

Law discriminates not just about who can pair with whom, but about who can have sex or marry at all. Here, disability becomes im-

\footnotetext{
13 A comparative study would be very interesting, as there are various countries that have also had express restrictions (such as South Africa) and other countries with no such history of racebased requirements for marriage (such as New Zealand). See, e.g., SoUTH AFRICA: A COUNTRY STUDY 54-58 (Rita M. Byrnes ed., 3d ed. I997); Victoria Freeman, Attitudes Toward "Miscegenation" in Canada, the United States, New Zealand, and Australia, I860-1914, I6 NATIVE STUD. REV. 4I, 54 (2005). This particular Article, however, looks only at U.S. law.

14379 U.S. I84 (I964) (declaring unconstitutional Florida's law banning interracial cohabitation but not same-race cohabitation)

15388 U.S. I (1967) (declaring unconstitutional Virginia's ban on interracial marriage).

16539 U.S. 558 (2003) (overturning Bowers v. Hardwick, 478 U.S. I86 (I986), and striking down Texas's sodomy law).

17 E.g., Brief of the CATO Institute as Amicus Curiae in Support of Petitioners at I0-I8, Lawrence, 539 U.S. 558 (No. 02-I02), 2003 WL I52342; William N. Eskridge, Jr., Privacy Jurisprudence and the Apartheid of the Closet, 1946-196I, 24 FLA. ST. U. L. REV. 703, 773-77 (1997).

18 See, e.g., Defense of Marriage Act, Pub. L. No. I04-I99, I Io Stat. 24I9 (I996) (codified in scattered sections of 28 U.S.C. and I U.S.C.); Kerrigan v. Comm'r of Pub. Health, 957 A.2d 407 (Conn. 2008); Goodridge v. Dep't of Pub. Health, 798 N.E.2d 94 I (Mass. 2003). The status of marriage is currently in flux in California. After the California Supreme Court ruled that the state constitution required that same-sex couples be allowed to marry, see In re Marriage Cases, I 83 P.3d 384 (Cal. 2008), the constitution was amended by referendum to ban same-sex marriage, CAL. ConsT. art. I, $\S 7.5$ (codifying Proposition 8, passed Nov. 4, 2008). The (state) constitutionality of this amendment was before the California Supreme Court at the time this Article went to press.
} 
portant. ${ }^{19}$ Those below a certain mental capacity cannot legally consent to sexual or marital relations in many states. ${ }^{20}$ Eugenic sterilization, upheld by the Supreme Court in Buck v. Bell ${ }^{21}$ with the infamous conclusion that "[t]hree generations of imbeciles are enough," 22 has operated alongside institutionalization to restrict the intimate possibilities of people with mental disabilities, casting them as both vulnerable victims and sexual predators. ${ }^{23}$ The history of eugenic restrictions on marriage has also prohibited people with some physical as well as mental disabilities from marrying. ${ }^{24}$

19 Age is also relevant here, under the rubric of restrictions on who can have sex or marry at all (although most people age out of such restrictions), Moe v. Dinkins, 533 F. Supp. 623 (S.D.N.Y. I98I), as well as under the rubric of restrictions on which individuals can marry which particular others (think statutory rape laws). Age raises challenging issues of its own, which, though interesting, are not a focus of this Article.

20 See, e.g., Denno, supra note 9, at 397-434 (cataloguing the relevant laws); sources cited infra note 24 (quoting examples).

21274 U.S. 200 (1927).

22 Id. at 207 ; see also, e.g., N.C. GEN. STAT. § 35-36 (repealed 2003) (providing for involuntary sterilization of "mentally retarded" persons).

23 See, e.g., City of Cleburne v. Cleburne Living Ctr., Inc., 473 U.S. 432, 463 (I985) (Marshall, $\mathrm{J}$., concurring in the judgment in part and dissenting in part) ("Segregation was accompanied by eugenic marriage and sterilization laws that extinguished for the retarded one of the 'basic civil rights of man' - the right to marry and procreate. Marriages of the retarded were made, and in some States continue to be, not only voidable but also often a criminal offense. The purpose of such limitations, which frequently applied only to women of child-bearing age, was unabashedly eugenic: to prevent the retarded from propagating. To assure this end, 29 States enacted compulsory eugenic sterilization laws between I907 and 193I." (footnotes and citation omitted)); FIELD \& SANCHEZ, supra note 9, at 55-92; Denno, supra note 9; Matthew J. Lindsay, Reproducing a Fit Citizenry: Dependency, Eugenics, and the Law of Marriage in the United States, I860-1920, 23 LAW \& SoC. INQUiRY 54I (I998); Michael A. Rembis, Disabling Sex (Aug. 2008) (unpublished manuscript, on file with the Harvard Law School Library). Skinner v. Oklahoma, 3 I6 U.S. 535 (I942), is sometimes thought to have overruled Buckv. Bell, but Skinner was about sterilization of criminals, and thus did not directly overrule the eugenic agenda of sterilization of people with mental disabilities. Skinner created legal uncertainty, however, and anything associated with the term eugenics - at least at the level of rhetoric — fell out of favor after World War II. On the rise and fall of the discourse of eugenics as it has shaped the history of miscegenation, see RACHEL F. Moran, INTERRaCial Intimacy: The REgulation of RaCE \& Romance 8I99 (200I).

24 For some laws that have been repealed or struck down, see, for example, CONN. GEN. STAT. § I354 (I958) (repealed I969) ("Every man and woman, either of whom is epileptic, imbecile, or feeble-minded, who shall intermarry, or live together as husband and wife, when the woman is under forty-five years of age, shall be imprisoned not more than three years."); UTAH CODE ANN. § 30-I-2(I) (I989) (amended I987) (prohibiting and voiding any marriage with "a person afflicted with acquired immune deficiency syndrome"), invalidated by T.E.P. v. Leavitt, 840 F. Supp. i io (D. Utah I993). For some laws remaining on the books, see, for example, D.C. CODE ANN. § 46-403 (LexisNexis 200I) (declaring as illegal and void any "marriage of an idiot or of a person adjudged to be a lunatic"); 23 PA. CONS. STAT. ANN. § I304(c) (West 200 I) ("No marriage license may be issued if either of the applicants for a license is weak minded, insane, of unsound mind or is under guardianship as a person of unsound mind unless the court decides that it is for the best interest of the applicant and the general public to issue the license and authorizes the issuance of the license." (repealed as to "epilepsy")). For further discussion, see Denno, supra note 9; Harlan Hahn, Feminist Perspectives, Disability, Sexuality and Law: New Issues and 
These explicit legal interventions in intimate discrimination suggest three types of norms. First, in the context of race, law inscribed a norm of homogamy (pairing with members of the same group ${ }^{25}$ ): particularly across the black/white color line, ${ }^{26}$ people could only legally partner - in sex or marriage - with people of their own race.

Second, the norm surrounding sex/gender runs directly contrary to that surrounding race. Rather than requiring pairs of the same type, the norm surrounding sex/gender requires pairing with a different type. In other words, the norm is of heterogamy. And unlike the race norm of homogamy, which has been purged from (explicit) law, ${ }^{27}$ the sex norm of heterogamy remains inscribed in law. ${ }^{28}$

Third, while law and norms play matchmaker when it comes to sex and race, the norm surrounding disability has typically been one of utter isolation, or desexualization: by express legal mandate, some people with disabilities have been excluded from the realm of sex and marriage altogether. ${ }^{29}$ Some of these laws are consigned to history, while others remain on the books. ${ }^{30}$

The next three sections will elaborate the extralegal life of these norms, through material drawn from statistics, dating websites, and literature. This combination of sources complements the preceding account of law by offering breadth and depth to our understanding of the norms of intimate discrimination. Statistics provide a broad empirical snapshot of intimate relations. Analyzing the structure of dating websites shows how these norms shape a national dating arena of tremendous and increasing popularity. ${ }^{31}$ And examining one fictional

Agendas, 4 S. CAL. Rev. L. \& Women's STUd. 97, I2 I-23 (I994); and David Pfeiffer, Eugenics and Disability Discrimination, 9 DISABILITY \& SOC'Y 48 I, 485-86 (I 994).

25 The root "-gamy" refers specifically to marriage, but like "monogamy," the term "homogamy" embraces a wider set of relational practices than just those associated with marriage.

26 The race-related norms and laws have been far more complicated than the black/white line would suggest, embracing and proscribing various color combinations with widespread local variations. For an excellent and evocative discussion of these complexities, among others, see MORAN, supra note 23.

27 Though explicit race-based restrictions on sex and marriage are a thing of the past, fears of miscegenation have shaped the incomplete project of desegregation. See infra notes 330-33 and accompanying text.

28 The norm is still actively inscribed in the civil law of marriage in most states, though it has been eliminated from the criminal law of sexual behavior. See supra notes I6-18 and accompanying text.

29 See sources cited supra notes $20-24$.

30 See sources cited supra note 24.

31 See, e.g., Mary Madden \& Amanda Lenhart, Online Dating i (2006), http://www. pewinternet.org/pdfs/PIP_Online_Dating.pdf (reporting that "among the relatively small and active cohort of Io million internet users who say they are currently single and looking for romantic partners, $74 \%$ say they have used the internet in one way or another to further their romantic interests" and that "there is relatively broad public contact with the online dating world because significant numbers of Americans personally know others who have tried and succeeded at online dating”); Rufus Griscom, Why Are Online Personals so Hot?, WIRED, Nov. 2002, at I35, I35, 
text for each category allows a sustained and textured encounter with what are ultimately highly contextualized attitudes and behaviors. The order of the categories discussed will loosely track the chronology of repeal of express marital restrictions, from race, to disability, to sex. ${ }^{32}$ The Part will conclude by examining the ways these intimate norms filter into the employment domain and skew courts' perception of illegal discrimination.

\section{B. Homogamy: Race}

The norm surrounding race is homogamy: within-group pairing. Our cultural platitudes in general include competing theories of attraction: "opposites attract," but "birds of a feather flock together" and "like attracts like." Richard Epstein uses the last of these phrases "[1]ike attracts like" - to argue that homogeneity is desirable in the workplace, because people like to be around those who are like them. ${ }^{33}$ At least in the intimate domain, Epstein has the right catchphrase for the pervasive understanding of race. Mary Becker, though writing from a very different normative position than Epstein, similarly asserts that "[w]e all empathize best with those most like ourselves." 34 This section portrays the norm of homogamy through statistics on interracial dating and marriage, an examination of the structure of mainstream dating websites, and a discussion of a short story by Derrick Bell.

I. Statistics. - The homogamy norm for race is reflected in statistics on rates of interracial marriage and dating. I briefly review a few of these figures, which show that rates of interracial marriage and dating, though on the rise, are well below what would be expected from random matching. In addition, the interesting variations in the data across gender and race point toward an explanation that is at least partly cultural.

(a) Rates of Interracial Marriage and Dating Are Rising. - In 2000 , just over $5 \%$ of all married couples included spouses of different

available at http://www.wired.com/wired/archive/ıO.I I/view.html?pg=2 (noting that "one in five singles looks for love on the web" and predicting that "[t]wenty years from now, the idea that someone looking for love won't look for it online will be silly, akin to skipping the card catalog to instead wander the stacks because 'the right books are found only by accident'").

32 Although marital restrictions remain in effect for some disabilities in some states, see sources cited supra note 24 , the sex-based restrictions on marriage remain more widespread, see supra p. I315; indeed, the latter are nearly universal.

33 Richard A. Epstein, Forbidden Grounds: The Case Against Employment DISCRIMINATION LAWS 68 (I992) (internal quotation marks omitted). For further discussion, see infra $\mathrm{p} . \mathrm{I} 337-38$.

34 Mary E. Becker, Needed in the Nineties: Improved Individual and Structural Remedies for Racial and Sexual Disadvantages in Employment, 79 GEO. L.J. I659, I67 I (I99I). Her different normative position is evident in the rest of her sentence, which is "but we live in a society in which white men disproportionately hold positions of power." Id. 
races, whereas in 1970 that figure was less than $1 \% .35$ Rates for dating are much higher, particularly among young people. According to a 2005 Gallup poll, $60 \%$ of I8- to 29 -year-olds have dated interracially, compared with $53 \%$ of 30 - to 49 -year-olds, $46 \%$ of 50 - to 64 -year olds, and $28 \%$ of those 65 and older. ${ }^{36}$ Favorable attitudes have risen faster and higher than interracial dating behavior, even among the youngest group. In a 2007 Pew research poll, $83 \%$ of Americans agreed with the statement, "I think it's alright for blacks and whites to date each other." 37 This is up from $48 \%$ in a 1987 poll. ${ }^{38}$

(b) Rates of Interracial Marriage Are Still Well Below What Would Be Expected from Random Pairing. - By one calculation, $44 \%$ of all U.S. marriages would be interracial under random matching weighted by the size of the relevant groups, ${ }^{39}$ a figure far higher than the marriage rates cited above. ${ }^{40}$ In their study of speed dating among Columbia University graduate students, Raymond Fisman and colleagues reported a level of cross-race interest that was closer to what randomness would predict: $47 \%$ of the matches were cross-race, which was a statistically significant difference from the $53 \%$ that the authors say random matching would predict, yet much closer than for the general population figures. ${ }^{41}$ The closeness of Fisman's figures to random matching may reflect both the fact that higher education levels are a

35 Sharon M. Lee \& Barry Edmonston, New Marriages, New Families: U.S. Racial and Hispanic Intermarriages, POPULATION BULL., June 2005, at I I.

36 Jeffrey M. Jones, Most Americans Approve of Interracial Dating, Gallup, Oct. 7, 2005, http://www.gallup.com/poll/r 9033/Most-Americans-Approve-Interracial-Dating.aspx (describing the Gallup annual Minority Rights and Relations Poll).

37 News Release, Pew Research Ctr. for the People \& the Press, Political Landscape More Favorable to Democrats 39 (Mar. 22, 2007), available at http://people-press.org/reports/pdf/3 I 2.pdf.

38 Id.

39 Raymond Fisman et al., Racial Preferences in Dating, 75 Rev. ECON. STUd. II 7 , II 7 (2008) (calculating this figure based on the U.S. population regardless of age, but asserting that "[a]lternative measures that restrict the calculation to 'marriageable' populations yield a similar figure," $i d$. at II 7 n.I).

40 Of course, the marriage rates encompass people who entered their marriages at different historical moments.

41 Fisman et al., supra note 39, at I23. The authors also report that women more than men showed racially homogamous preferences; I look forward to further study of this result, because there seem to be so many possible explanations, prominent among them that the women were more interested in relationships and the men more in sex. The authors discount this explanation on the basis that their older participants showed more heterogamous preferences, despite being more interested in relationships. Id. at 4 . This triangulation via older subjects does not seem an adequate basis for rejecting the different-dating-aims theory for women's homogamous choices. (The triangulation might seem a particular problem if the older subjects were old enough that they were past the age of thinking about creating biological children, but apparently even the older subjects in this study were nearly all too young for that point to apply. Conversation between Raymond Fisman and author (Sept. I0, 2008)). 
predictor of willingness to date interracially and the fact that people are generally more open to interracial dating than marriage. ${ }^{42}$

(c) Rates of Interracial Marriage and Dating Vary by Race and Gender. - Gallup reports that as of $2005,69 \%$ of Hispanics, $52 \%$ of blacks, and $45 \%$ of whites had dated interracially at some point. ${ }^{43}$ Another study, using data from 1999-2000, found the following percentages of interracial dating among these groups: 57.I\% of Asian Americans, $56.5 \%$ of African Americans, $55.4 \%$ of Hispanic Americans, and $35.7 \%$ of European Americans. ${ }^{44}$ This study reports that while African Americans are as likely to date interracially as other minority groups, they are less likely to marry interracially. ${ }^{45}$

With regard to gender and race, African American men are much more likely to marry white women than white men are to marry African American women. From I970 to 2000 , black men increased their rate of marrying white women almost sixfold, so that by 2007 , nearly $6 \%$ of black men were married to white women. ${ }^{46}$ Fewer than half as many - approximately $2.9 \%$ of — black women were married to white men. ${ }^{47}$ The opposite gender effect occurs among Asian American and white pairings. As one recent analysis reports, "Until i960, Asian men were more likely than Asian women to intermarry with whites. By the 2000 census, however, this trend had reversed. Asian women are almost twice as likely to marry a white person as Asian men." 48

The vastly different rates of interracial relationships for African American men as opposed to women, and Asian American women as opposed to men, unsettle any simple conclusion of a general preference for partners of the same race (that is, homogamous mating, also called "(positive) assortative mating"). Sociobiologists have spilt much ink explaining the potential benefits of endogamy — often with an assumption that this just is what people tend to do, and so we need an

\footnotetext{
42 See Fisman et al., supra note 39, at I23; infra note 169 and accompanying text.

43 Jones, supra note 36.

44 George Yancey, Who Interracially Dates: An Examination of the Characteristics of Those Who Have Interracially Dated, 33 J. COMP. FAM. STUD. I79, I83 (2002). These generalizations do not reflect variations in intermarriage rates across different Asian American groups.

45 Id.; see also Richard Lewis, Jr., George Yancey \& Siri S. Bletzer, Racial and Nonracial Factors That Influence Spouse Choice in Black/White Marriages, 28 J. BLACK STUD. 6o, 64 (I997). In Rachel Moran's words, "The critical divide may no longer be between whites and nonwhites but between blacks and nonblacks." MORAN, supra note 23, at I 75 (footnote omitted).

46 Roland G. Fryer Jr., Guess Who's Been Coming to Dinner? Trends in Interracial Marriage over the 2oth Century, J. ECON. PERSP., Spring 2007 , at $7 \mathrm{I}, 77$.

47 Id.; see also Kellina M. CRAig-Henderson, Black Men in InTERracial Relationships i5 n.i i (2006) (citing National Urban League, The State of Black America 200I, for the proposition that African American men are three times more likely to marry across race than are African American women).

48 Fryer, supra note 46 , at 77 .
} 
evolutionary "just so story" as to why. ${ }^{49}$ Yet other explanations must be considered, including the different social meanings of specific gender and race pairings, ${ }^{50}$ the potential role of who (that is, men or women) tends to initiate dating, ${ }^{51}$ implicit associations between gender and race, ${ }^{52}$ in-group pressure on African American women to preserve the black family, ${ }^{53}$ and the maternalization of African American women as caretakers in white homes, ${ }^{54}$ to name a few. ${ }^{55}$ Whatever contribution sociobiological explanations may make to our understanding of race and intimacy, the complicated interplay of gender and race in these statistics suggests that sociobiology cannot end the discussion.

In sum, while rates of interracial dating and marriage have increased, they have not increased nearly as much as favorable attitudes, nor do they reflect what random sorting would predict. This may be unsurprising, but the gender contours of these statistics also trouble any quick explanations.

49 Theories include, for instance, that homogamy increases altruism among relatives or marital stability and thus increases fitness. See Del Thiessen, Robert K. Young \& Melinda Delgado, Social Pressures for Assortative Mating, 22 Personality \& Individual Differences i57, I57-58 (I997). The work on positive assortative mating tends to be particularly impressed that the phenomenon can occur even for disabilities, such as deafness or psychiatric impairment. See, e.g., Del Thiessen \& Barbara Gregg, Human Assortative Mating and Genetic Equilibrium: An Evolutionary Perspective, i ETHOLOGY \& Sociobiology i i I, I I6-I 7 (I980).

50 For instance, the historical fear of black male/white female sexual relations is of course deeply implicated in some of the ugliest features of American racism, from lynching to the origins of the Ku Klux Klan. It bears a different set of meanings than the no less ugly but distinct legacy of white men's appropriation of black women's bodies and claim to sexual access under slavery. See, e.g., Craig-Henderson, supra note 47, at 23-26; see also R. Richard Banks, The Aftermath of Loving v. Virginia: Sex Asymmetry in African American Intermarriage, 2007 WIS. L. REV. $533,536-37$ (discussing other scholars' views of the importance of this history to the gender gap in black-white marriage)

51 See, for example, CRAIG-HENDERSON, supra note 47 , at 88-89, for a discussion of the theory that if racial pairing is affected by conscious or unconscious social climbing, then perhaps the gendered expectation of male initiation of dating means that men will tend to date up or across but not down the social hierarchy. This theory, which Craig-Henderson is not endorsing, leaves something to be desired as a response to the gender patterns in Asian-white relationships. See id.

52 Some provocative new work in social psychology by Phillip Goff and colleagues suggests that implicit bias and stereotypes might play a role in interracial intimate relationships. See Phillip Atiba Goff, Margaret A. Thomas \& Matthew Christian Jackson, “Ain't I a Woman?”: Towards an Intersectional Approach to Person Perception and Group-Based Harms, 59 SEX Roles $39^{2}$ (2008). Their work suggests that African American men are perceived (by a subject pool of mostly white students) as more masculine than white men - perhaps not entirely surprising but apparently the same goes for African American women, whom white observers more often mistake for men than they do white women. $I d$. at 400 . The same study also suggests that Asians — both men and women - are perceived as more feminine. See Margaret A. Thomas \& Phillip Atiba Goff, Pain at the Crossroads: How Intersectionality Works and Hurts (Jan. 2009) (unpublished manuscript, on file with the Harvard Law School Library).

53 See Banks, supra note 50, at 54I.

54 See, e.g., MORAN, supra note 23, at 104 (describing the portrayal of black women as "asexual and motherly" (footnote omitted)).

55 For further discussion, see Robinson, supra note 4, at 2803-08. 
2. Websites. - The commercial dating market provides a revealing glimpse into private preferences and expectations surrounding them. ${ }^{56}$ Of particular interest to this discussion of intimate norms is the structure these companies impose on desire through the questions they ask in order to organize participants.

Dating websites and speed dating companies ask for information about sex and race and organize people according to their answers. An inspection of popular mainstream dating sites ${ }^{57}$ reveals some notable features across the identity categories at issue in this Article, as this and subsequent sections will discuss. Race is a salient category on all the mainstream sites, though it is presented more subtly than sex. Race is never on the initial introductory page, which typically contains only sex, age, and geography. But all these sites allow you to indicate your racial preferences or search by race. ${ }^{58}$ All ask for your race, and some require you to state it. ${ }^{59}$

Perhaps most strikingly, the site Singlesnet assumes homogamous preferences in the way it asks about racial preferences, inquiring "Would you consider dating someone from a different race?" with only "yes" or "no" options. ${ }^{60}$ The structure of this question is worth pausing over, as it reflects the way assumed norms operate. The question is

56 Several scholars have made excellent use of personal ads and dating websites to demonstrate, among other things, the striking ways that race still explicitly organizes so many people's private lives. See, e.g., Robinson, supra note 4; Note, Racial Steering in the Romantic Marketplace, IO7 HARV. L. REV. 877 (I994); see also KENNEDY, supra note Io, at 27-37.

57 An online site provides rankings of the most popular dating sites from three "dating service ranking companies": Hitwise, Comscore, and Nielsen-Netratings. InternetDatingUSA.com, Best Dating Sites, http://www.internetdatingusa.com/online-dating-site-rank.htm (last visited Feb. 8, 2009). As of December 2007 , the sites that appear on those three top ten lists combined, which I consider a useful proxy for mainstream popularity, are as follows (in rough order of combined popularity): Yahoo Personals, http://personals.yahoo.com; Match.com, http://www.match.com; Singlesnet, http://www.singlesnet.com; True.com, http://www.true.com; eHarmony, http://www. eharmony.com; American Singles, http://www.americansingles.com; Mate I, http://www.mate I. com; Black People Meet, http://www.blackpeoplemeet.com; gay.com, http://www.gay.com; Black Singles, http://www.blacksingles.com; Date.com, http://date.com; and Lavalife, http://www. lavalife.com (all sites last visited Feb. 8, 2009).

58 As noted, my emphasis here is on sites dedicated to dating. See supra note 57. However, it is interesting to note that the popular social networking site Facebook, http://www.facebook.com (last visited Feb. 8, 2009), does not ask for race and allows participants to choose whether they want their sex displayed. Uploading pictures is popular and serves a similar function to stating these features in many cases, though revealing this information through pictures alone does not allow searches by race in the way that a drop-down menu would. Though Facebook is a tool for friendship for many, it also invites participants to indicate their relationship status and the sex they are seeking (male, female, or both) and so can be used for dating purposes as well.

59 For instance, eHarmony asks for your ethnicity and asks, "What ethnicities would you be willing to accept as matches?" and "How important is your match's ethnicity?" You cannot proceed beyond that page unless you answer these questions.

60 In addition, while most questions on the initial registration page provide further submenus when you answer yes to a question, no further questions (such as, perhaps, "which race?") follow this question. The question is only whether you would consider interracial dating. 
not, "Would you consider dating someone of your own race?" The latter would likely sound preposterous as a general question. ${ }^{61}$ Even in a world of multifarious possibilities, the assumed move is to date - and marry - within one's own race.

3. Literature. - The race homogamy norm has been depicted in a wide array of films and print fiction. ${ }^{62}$ Though only one such example, Derrick Bell's story, The Last Black Hero, usefully articulates the norm's strength and consequences within both black and white culture. This fictional account of the relationship between a wounded hero of race politics, Jason Warfield, and his white doctor, Sheila Bainbridge, ${ }^{63}$ elaborates the potential consequences of interracial love from both white and black society. Sheila faces the racism of her colleagues at the hospital who, "appalled at her relationship with a Black man,... suspended her for allegedly violating their doctor-patient regulations," despite her "scrupulous . . . dealings with Jason," including ceasing her treatment of him when she realized her feelings. ${ }^{64}$ (Such grossly unlawful treatment of a white employee for an interracial relationship might seem outdated, a thing of the past, but for recent case law to the contrary. ${ }^{65}$ ) More important for both lovers, however, is the meaning of their relationship to the black community: if Jason, "a Black, political leader who espoused pride in Blackness," married a white woman, how could that act, "at the very least, [not] shift[] [Jason's organization's] energies from its racial reform goals to a divisive and likely interminable debate over the rightness and propriety of his marital choice?"66 The story depicts Jason's internal struggle:

Jason had never advocated hate for whites as a component of his uniquely successful Black pride program. ... [B]ut [his program] did everything it could to encourage Black men to "look to the sisters and do not forsake them. For in Black women," he urged, "you will find both counsel and ci-

61 There are of course some contexts in which this would not be a surprising question, such as if posed to a person with a history of having a particular racial type not her own. For a discussion of "types" of this sort, see infra section II.A.4, pp. I343-44.

62 For an excellent review of this literature, see KENNEDY, supra note 1o, passim. See also, e.g., infra notes 216, 294 (discussing some such films).

63 Derrick Bell, The Last Black Hero: A Chronicle of Interracial Love and Sacrifice, 8 HARV. BLACKLETTER J. 275 (I99I).

$64 I d$. at 282.

65 See, e.g., Holcomb v. Iona Coll., 52 I F.3d I30, I3 I-32 (2d Cir. 2008) (reversing summary judgment for the defendant in a claim brought by an associate head basketball coach allegedly fired for his interracial relationship). The court recounted among the plaintiff's facts the following comment (also heard by a third party) by a vice president of the college, when asked by the plaintiff if he had received the plaintiff's wedding invitation: "[Y]ou're really going to marry that Aunt Jemima? You really are a nigger lover." Id. at I34 (alteration in original) (internal quotation marks omitted).

66 Bell, supra note 63 , at 280 . 
vility, love and support, friendship and faithfulness, probity and integrity.

For the Black man, the Black woman is the equivalent of home." ${ }^{67}$

Yet he loved a white woman, and he had always railed against the (white) American tradition of sacrificing individual black material interests to some larger political project of society. ${ }^{68}$

The story also depicts the pain of rejection felt by Neva, the black woman to whom Jason had planned to propose, who served as his deputy in their political organization. When Neva learns about Jason's relationship with Sheila, her mother asks her, "Suppose Jason's doctor had been Black? Would you feel less hurt?" 69 Neva responds, "I would be disappointed as a woman who lost her man, but I would not feel rejected as a person." "7o

When Neva, Sheila, and Jason all meet, Sheila first proclaims that she cannot marry Jason and do such an injustice to the African American community. But Neva rejects this "martyrdom" from a white woman, insisting that Sheila's services will be more useful, and her commitment to the community more meaningful, if she comes back with Jason and takes a staff position at Jason's organization. ${ }^{71}$ Eventually Sheila agrees. The narrative concludes with the interracial couple planning to travel to New York to try to brave the storm of outrage they will undoubtedly face both from Jason's organization and from the black community more broadly. In the final lines of the story, Jason contemplates his failure as a hero, and the need for reality and faith over heroism. ${ }^{72}$ The pressures of the homogamy norm take Jason to self-abnegation and ultimately prayer, in an ending that leaves the reader with little confidence that the result of this love will be anything less than a terrible injury to his advocacy community, and the loss of everything for him and his beloved, whose own career has already been seriously damaged by her love of him. The story portrays some of the ongoing challenges faced by interracial couples, and dramatizes the significance of the homogamy norm not only to superordinate groups, but to subordinate groups, who may value solidarity in both public and private realms.

67 Id. at 279 .

68 See id. at $28 \mathrm{I}$.

69 Id. at 284 (internal quotation mark omitted).

70 Id. (internal quotation marks omitted).

71 See id. at 287-88.

$72 \mathrm{See} i d$. at 289 . 


\section{Desexualization: Disability}

Important recent work in disability studies has called attention to the desexualization of disabled people. ${ }^{73}$ As Tom Shakespeare has written, "disability is a very powerful identity, and one that ... has the power to de-sex people, so that people are viewed as disabled, not as men or women, straight or gay."74 In one study, "college students were asked to free associate with the terms 'woman' and 'disabled woman." 75 The students associated "sexuality, sexual relations, and mothering with the former, but loneliness and lifelessness with the latter." ${ }^{\prime 6}$ The relationship between disability and sexuality is complicated. In some representations, disabled people seem presumptively hypersexual, rather than nonsexual. ${ }^{77}$ But such attributions of heightened or uncontrolled libido again serve as a justification for denying the sexuality of disabled people - to prevent them from imposing their sexuality on others and potentially tainting the human race. ${ }^{78}$ In this way, even when the depictions or assumptions vary, the norm of desexualization remains fairly robust.

I. Statistics. - Although disability studies scholars have worked to dispel the myth that people with disabilities are not sexual beings, ${ }^{79}$

73 See, e.g., Tom Shakespeare, Kath Gillespie-Sells \& Dominic Davies, The SEXuAl Politics OF Disability (I996).

74 Tom Shakespeare, Disability, Identity and Difference, in ExPLORING THE DIVIDE: ILLNESS AND DisABILITY 94, I09 (Colin Barnes \& Geof Mercer eds., I996). Susan Stefan makes a similar point specifically about people with psychiatric disabilities, writing that "[t]heir identity as psychiatrically disabled swallow[s] all other aspects of who they were - their sexuality, their religious identity, and their racial or ethnic identity." Susan Stefan, "Discredited" and "Discreditable": The Search for Political Identity by People with Psychiatric Diagnoses, 44 WM. \& MARY L. REV. I34I, I363 (2003). For foundational work on both the societal resistance to recognizing the sexuality of people with mental disabilities, particularly in institutions, and the concept of sanism, see Michael L. Perlin, Hospitalized Patients and the Right to Sexual Interaction: Beyond the Last Frontier?, 20 N.Y.U. REV. L. \& Soc. CHANGE 5 I 7 (I993-I 994).

75 Anita Silvers, Reprising Women's Disability: Feminist Identity Strategy and Disability Rights, I3 BERKELEY WOMEN'S L.J. 8I, 90 (I998).

76 Id.

77 For instance, see Deborah Denno's discussion of the competing presentations of disabled girls as alternatively nonsexual (by prosecutors) and hypersexual (by defense attorneys) in recent trials of men accused of having nonconsensual sex with mentally disabled girls. Denno, supra note 9, at 324. Michael Rembis shows a similar dynamic in historical portrayals of girls institutionalized for alleged mental impairment in the first half of the twentieth century. Rembis, supra note 23. Interestingly, one study finds that nondisabled men, but not women, are inclined to attribute to disabled people a "greater interest in sexual activities." Kristen Robillard \& Catherine S. Fichten, Attributions About Sexuality and Romantic Involvement of Physically Disabled College Students: An Empirical Study, 6 SeXuality \& Disability i97, I97 (I983).

78 See sources cited supra note 77; see also supra section I.A, pp. I3 I5-18 (discussing eugenicsbased legal restrictions).

79 See, e.g., Robert W. Baer, Is Fred Dead? A Manual on Sexuality for Men With SPINAl CORD INJURIES (2003); Ken Kroll \& ERICA LEvy Klein, ENABling RoMANCE: A Guide to Love, SEx, AND Relationships FOR the Disabled (AND the People Who Care About Them) (r992); Michael A. Rembis, Beyond the Binary: Rethinking 
it remains true that many disabled people continue to have more limited sexual and romantic opportunities than nondisabled peers. People with disabilities are less likely to be married than people without disabilities. The latest U.S. Census data indicate that, among people between the ages of 25 and $64,67.6 \%$ of nondisabled people are married, as opposed to $59.6 \%$ of people with disabilities that are not severe, and $50.1 \%$ of people with severe disabilities. ${ }^{80}$ The 2006 National Health Interview Survey shows a comparable gap between disabled and nondisabled people: among adults in general (those over age I8), $46.3 \%$ of those with disabilities are married, as opposed to $59.8 \%$ of those without disabilities. ${ }^{81}$ People with disabilities are also less likely to be sexually active, with the gap apparently more pronounced for congenitally acquired impairments than for those acquired late in life. ${ }^{82}$

2. Websites. - Disability is almost entirely absent from the mainstream dating websites, ${ }^{83}$ suggesting, I think, its assumed importance (that is, its status as disqualifying). The main exception is Date.com, which allows people to list "disabled" under their own "body type," and to search for (or not to search for) "disabled" under the "body type" they are seeking. In addition, True.com includes American Sign Language among its languages spoken or sought. No other mainstream site that I consulted mentions disability in any way.

Marginal dating sites fill the gap for disabled people and, in so doing, articulate the exclusion felt by disabled people on the mainstream sites. For instance, the disability-related site Lovebyrd.com is "exclusively" for disabled people, including most every disability imaginable. Indeed, Lovebyrd's proprietors assert that they will adjust their site's structure to include your disability in the drop-down menu within sev-

Sexualities and Disabilities (June 2008) (unpublished manuscript, on file with the Harvard Law School Library); see also Michael Ashley Stein, From Crippled to Disabled: The Legal Empowerment of Americans with Disabilities, 43 EMORY L.J. 245, 260 n.97 (I994) (referring to "the common myth that disabled people are sexless").

80 U.S. Census Bureau, Americans With Disabilities: 2002, at 23-24 thl.4 (2006), available at http://www.census.gov/hhes/www/disability/sipp/disabo2/dso2t4.pdf.

81 E-mail from H. Stephen Kaye, Inst. for Health \& Aging, Univ. of Cal., S.F., to Becca von Behren, research assistant to author (Apr. I0, 2008, 10:47) (on file with the Harvard Law School Library).

82 See, e.g., J.C. MacDougall \& S. Morin, Sexual Attitudes and Self-Reported Behavior of Congenitally Disabled Adults, I I CAN. J. BEHAV. SCI. I89, I89 (I979) (reporting, in a study of fortyfive congenitally disabled adults, that over half of the subjects had never had a sexual experience with another person); Marita P. McCabe \& George Taleporos, Sexual Esteem, Sexual Satisfaction, and Sexual Behavior Among People with Physical Disability, 32 ARChIVEs OF SeXUAL Behav. 359 (2003); Diana H. Rintala et al., Dating Issues for Women with Physical Disabilities, I5 SEXuAlity \& DisABILITy 2 I9 (I997); Eric R. Wright et al., Stigma and the Sexual Isolation of People with Serious Mental Illness, 54 Soc. Probs. 78 (2007).

83 See supra note 57 (explaining how mainstream sites were identified). 
enty-two hours if your disability is not on their list. ${ }^{84}$ One might ask, in response to this site: Why would a person with "visual problems" have any specialized interest in dating a person who is "bipolar" or who has "Down syndrome"? Why would disabled people want an exclusive in-group setting for date seeking?

Lovebyrd itself provides an answer:

Disabled singles complain that it is more difficult to meet someone on a mainstream dating site when you have a disability. That is mainly because other members do not know you have a disability until you disclose this information yourself; and often when this fact is revealed, the interest of the counterparty is lost. ${ }^{85}$

3. "Literature." - In the mainstream dating scene, disability is often relegated to the status of a joke. The idea that a disabled person would be a desirable sexual or dating companion is treated as funny. This association is not new - indeed, Freud's writings on jokes include many jokes that turn on the humor of a matchmaker trying to pass off a bride who is disfigured or disabled. ${ }^{86}$ But let us pause here to consider a contemporary example for its depiction of the relation between disability and sexuality. ${ }^{87}$

Below is a "Joke of the Month!" from the men's magazine, Maxim. Before quoting it, I want to acknowledge that, to many, this is a very disturbing "joke," and not one experienced as funny. With my apolo-

${ }^{84}$ Lovebyrd.com, Who Can Join Lovebyrd.com?, http://www.lovebyrd.com/challenges.php (last visited Feb. 8, 2009).

85 Lovebyrd.com, Disabled Dating Services, http://www.lovebyrd.com/dating_services.php (last visited Feb. 8, 2009); see also, e.g., Kroll \& KLEIN, supra note 79, at 28. Paralympian swimmer Denise Beckwith poignantly expresses this difficulty in her profile in the elegant Intimate Encounters show of disabled "self-portraits" photographed by Belinda Mason-Lovering. Beckwith was photographed on a rock with a mermaid's tail; her caption read, "Like the little mermaid wanted love, I too yearn for that. I have been so close on numerous occasions. But as I have to stand up at some point (and use my crutches to walk) . . . and they are forced to realise I am disabled, they seem to become somewhat scared." Media Release, Intimate Encounters by Belinda Mason, A Photographic Exhibition Exploring Sexuality, Disability and Body Image (2007) (quoting Denise Beckwith), available at http://www.belindamason.com/art/pdfs/ mediareleases 2007 /intimate\%2oencounters.pdf; see also Belinda Mason, Intimate Encounters, http://www.belindamason.com/art/ie_07_05.html (last visited Feb. 8, 2009).

86 See Sigmund Freud, Jokes and Their Relation to the Unconscious 6i-65 (James Strachey ed. \& trans., W.W. Norton \& Co. I960) (I905). For instance:

The would-be bridegroom complained that the bride had one leg shorter than the other and limped. The Schadchen contradicted him: "You're wrong. Suppose you marry a woman with healthy, straight limbs! What do you gain from it? You never have a day's security that she won't fall down, break a leg and afterwards be lame all her life. And think of the suffering then, the agitation, and the doctor's bill! But if you take this one, that can't happen to you. Here you have a fait accompli." Id. at 62-63 (internal quotation marks omitted).

87 As with my discussion of the Bell story, see supra section I.B.3, pp. I323-24, this account examines one source closely; I do not pretend to represent the range of the many fictional sources available in print, film, and television. 
gies, I hope the reader will persist here, because jokes such as this can reveal shared cultural assumptions particularly starkly. Here it is:

Joke of the Month!

A man with no arms or legs is sunbathing on a beach. After a while he is approached by three gorgeous women, who take pity on him.

The first one says to him, "Have you ever been hugged?"

"Why, no, I can't say that I have," the man replies, shaking his head. So she leans down and gives him a hug.

The second woman says to him, "Have you ever been kissed?"

He shakes his head again. She kisses him.

Rather abruptly, the third asks, "Have you ever been fucked?"

"No," says the man, his eyes lighting up.

"Well, you are now. The tide's coming in." 88

Someone clearly found this joke funny: it is the Joke of the Month in a magazine with over 2.5 million readers. ${ }^{89}$ Why?

Maxim supplies its own answer. Above the joke is a cartoon of the scenario: A man whose sleeves and pant legs taper off to signify the missing arms and legs sits in a deck chair on the beach, surrounded by three voluptuous vixens in bikinis. He looks excited and embarrassed. A caption reads "Its [sic] funny "cause he's horribly disabled!" 90

Perhaps Maxim is right. Perhaps the mere fact of his disability is what makes the joke funny to its celebrants. There is of course humor based just on disability: one might think of Mr. Magoo almost falling from great heights because of visual impairment, or the genre of "guy with no arms and no legs" jokes, of which this is one. ${ }^{91}$ Laughing at disability can cause offense, making it a prime target for the Maxim humor page, which apparently trades in the shock value, or rebellious frisson, of saying "un-PC" things. ${ }^{92}$

88 Josh Richman, Joke of the Month!, MAxim, Jan. 2008, at I8 (joke submitted to the magazine "via email").

89 Magazine Publishers of America, Top ıоo ABC Magazines by Average Total Paid \& Verified Circulation, 2007, First Six Months, http://www.magazine.org/consumer_marketing/circ_ trends/25227.aspx (reporting "Total Paid \& Verified Circulation" for Maxim of 2,568,339).

90 Caption to Joke of the Month!, MAXIM, Jan. 2008, at I8.

91 See, e.g., No Arms and No Legs Jokes ..., http://www.geocities.com/heartland/hills/3456/ h_no_arms.html (last visited Feb. 8, 2009).

92 The page also includes the following "roasts," targeting sex, age, and race: "Dr. Ruth is so old, her pussy has mice" and "Shaquille O'Neal: "Your knuckles look scraped. Did you walk here?"” Jeffrey Ross, The Dean of Mean, MAXIM, Jan. 2008, at I8 (internal quotation marks omitted). 
But this joke is about something more: it is about disability and sexuality. The crucial moment is the turn from the man's hopeful expectation of sex to his being told he instead faces looming disaster. The pun on the word "fucked" - its double meaning of intercourse and ending up in dire straits - provides the vehicle for his disappointment. The women look down on him from the beginning, both literally and figuratively. They "pity" him; the first one "leans down" and gives him a hug. ${ }^{93}$ There may also be something in the active use of the verb "to fuck" by the woman. The question is not whether he has ever "fucked" a woman, which would situate him as the active partner, but whether he has ever "been fucked" by a woman.

The (presumptively straight male nondisabled) Maxim reader can feel reassured by the punchline. ${ }^{94}$ The world has been turned right side up again - back to the universe he expects - where beautiful women do not proposition disabled men. After being led along by the women's apparently kind approach, the reader who keeps thinking, "No, no, surely this guy isn't going to live out every guy's fantasy of sex with beautiful women on a beach," is then reassured, "Of course not." The Maxim reader can reassure himself that at least he is better than someone.

We might see the disabled character in the joke as representing a set of fears, of "existential anxieties" about disability, ${ }^{95}$ that makes the reader concerned to distance himself from this character. ${ }^{96}$ Then, when the character looks like he might get exactly what the reader wants, the anxiety increases. However, the pun saves the day, and the disabled guy is "fucked" in life rather than "fucked" in bed. Maxim's

93 The women's hug and apparent pity might read initially as maternal, particularly in light of the infantilization of disabled people that contributes to desexualization.

94 Indeed, it is not only nondisabled readers who might respond to the joke in this way; hierarchies of status operate within, as well as around, the disability community. And those who have a disability but do not identify as disabled may have particularly good reason to try to distance themselves from other disabled people, on a principle similar to that which underlies the word and concept of homophobia.

95 See Harlan Hahn, The Politics of Physical Differences: Disability and Discrimination, $44 \mathrm{~J}$. SOC. ISSUES 39, 43-44 (I 988 ).

96 The gender angle on the joke supports another kind of anxious identification between the reader and the disabled man on the beach: both are potential victims of feminine wiles. The cartoon above the joke helps bring this out, as the women look like female villains in a Disney movie, wily and catlike with exaggerated curves and sinister eyes. The reader's anxiety may go further, for, under a psychoanalytic account, dismemberment may evoke anxieties about impotence or castration. See Margrit Shildrick, Dangerous Discourses: Anxiety, Desire, and Disability, 8 STUD. GENDER \& SEXUALITY 22 I, 233-38 (2007). Under this account, such anxieties surround sex generally because of its perceived potential to restore the self to an early state of undifferentiated dependency, of pre-Oedipal polymorphous perversity - a prospect that is alluring yet also terrifying in its threat to the coherent self. Id. at 235 . When sexuality meets disability, Shildrick argues, the anxiety is overwhelming. $I d$. at 234 . 
cartoon caption thus serves to reassure the reader: "Its funny 'cause he's horribly disabled!" 97 Not you, that is - him. ${ }^{98}$

The joke thus shows several things. Most importantly, it depicts a set of assumptions: a disabled man who has never been hugged, much less kissed or bedded, and an apparent need to explain under what circumstances beautiful bikini-clad women would have sex with an amputee - out of "pity." The joke shows the ease with which a disabled character is treated as a ridiculous figure for aspiring to fulfilling sexual relations. This is normative desexualization.

And lest we think this desexualizing treatment of disability is confined to laddish or trivial cultural contexts, we need only turn to the pages of the Federal Supplement for contrary evidence. In a case from the late I990s involving a claim of associational discrimination under the Americans with Disabilities Act of $1990^{99}$ (ADA), a federal district court implicitly revealed its view of the likelihood of a disabled person engaging in sexual relations. Explaining what kinds of relationships the ADA's regulations assumed that disabled people would have, the court wrote:

As the regulations make clear, the ADA's purpose is to prevent discrimination against ... those who may have a close familial, social, or possibly even physical, relationship with a disabled person. The paradigmatic case is that of the parent of a disabled child, whose employer may fear that the child's disability may compromise the employee's ability to perform his or her job. ${ }^{100}$

A disabled person paradigmatically would have a parent, and may have a "social . . relationship." But a physical — that is, sexual — relationship is presented as almost inconceivable: "possibly even."

\section{Heterogamy: Sex}

Sex of course operates differently than either race (pairing inside one's group) or disability (not pairing at all). The norm for sex is heterogamy: pairing outside one's group. As Alan Sinfield says, "The only relation of difference that is validated is gender, and then only when a male and a female are involved."101 More colorfully, you may get

\footnotetext{
97 Caption to Joke of the Month!, MAxiM, Jan. 2008, at I8 (emphasis added).

98 The passive sexuality - figured through the disabled man cast as the object of the verb "to fuck" rather than the subject - might represent a sexual fantasy for some men, but one that needs to be disowned, pinned on someone else (to invoke Michael Warner's phrase, from another context), a distancing function that disability usefully serves. See MichaEL WARner, The TROUble WITH NORMAL 3 (I999).

99 Pub. L. No. IoI-336, I04 Stat. 327 (codified as amended in scattered sections of 42 U.S.C.).

100 O'Connell v. Isocor Corp., 56 F. Supp. 2d 649, 653 (E.D. Va. I999) (emphasis added).

101 Alan Sinfield, ON Sexuality AND POWER i4 (2004). Contra Sinfield's implication that sex is unique in this way, the family is another domain with regard to which heterogamy is assumed; that is, the incest taboo pushes a kind of intimate heterogamy. Judith Butler suggests
} 
called a narcissist for desiring people of your own sex, but you are not likely to get called a narcissist for desiring people of your own race or ability. ${ }^{102}$ U.S. law and norms have a long (though not uncomplicated) history of pushing heterogamous pairing with regard to sex. From marriage law to sodomy law to "no promo homo" statutes, ${ }^{103}$ this norm is immediately recognizable in law as well as culture. Indeed, the sex heterogamy norm is so assumed as to be invisible at times, even in academic writing; for example, work in sociology on relationship patterns sometimes speaks as if homogamy is generally the driving force in romantic pairings, without noticing that a starting point for most people is heterogamy with regard to one key category: sex. ${ }^{104}$

The heterogamy norm for sex - still inscribed in express legal restrictions on marriage - is so obvious as to render almost any description of it superfluous. This section is therefore brief, noting a few statistics and website features, then glossing a cultural artifact that highlights the heterogamy norm through parody.

I. Statistics. - Fewer people act on same-sex desires than have them, and even fewer identify as gay or lesbian. Specifically, according to some studies, $7.7 \%$ of men and $7.5 \%$ of women report having samesex desires, ${ }^{105}$ and $4.7 \%$ of men and $3.5 \%$ of women report having had at least one same-sex experience since the age of eighteen, ${ }^{106}$ as compared to the $2.8 \%$ of men and $\mathrm{I} .4 \%$ of women who report identifying as gay or lesbian (or bisexual). ${ }^{107}$ These numbers may well understate the prevalence of same-sex desire and experience, as other studies find higher rates, ${ }^{108}$ and of course the meaning of these data depends on

that the incest taboo is generative of all other sexual taboos. See JUDITH BUTLER, ANTIGONE'S CLAIM 7I (2000).

102 On psychiatry's historical linking of narcissism and homosexuality, see, for example, gayhistory.com, words: Narcissism, http://www.gayhistory.com/rev2/words/narcissism.htm (last visited Feb. 8, 2009).

103 William N. Eskridge, Jr., No Promo Homo: The Sedimentation of Antigay Discourse and the Channeling Effect of Judicial Review, 75 N.Y.U. L. REV. 1327 (2000) (discussing laws that prohibit the "promotion" of homosexuality through, for instance, teaching safer sex practices for same-sex, as well as cross-sex, conduct).

104 See, e.g., Lewis, Yancey \& Bletzer, supra note 45, at 6I-62.

105 Edward O. Laumann et Al., The Social Organization of Sexuality 297 (I994).

106 See Dan Black et al., Demographics of the Gay and Lesbian Population in the United States: Evidence from Available Systematic Data Sources 9 (Ctr. for Pol'y Res., Working Paper No. I2, I 999).

107 LAUMANN ET AL., supra note I05, at 293.

108 See, e.g., The Kinsey Institute, Data from Alfred Kinsey's Studies, http://www.indiana.edu/ kinsey/research/ak-data.html (last visited Feb. 8, 2009) (summarizing data from ALFRED C. Kinsey et Al., Sexual Behavior in the Human Male (i998) (i948); Alfred C. Kinsey et Al., Sexual Behavior in the Human Female (ig98) (I953) (reporting that $37 \%$ of males had had at least one same-sex experience to orgasm and that $13 \%$ of women had had such an experience)). 
many factors. ${ }^{109}$ But even these conservative estimates point to some kind of gap that, while impossible to verify definitively, seems to reflect the heterogamy norm expressly inscribed in the law of marriage.

2. Websites. - On the mainstream dating websites, sex is omnipresent, nearly always asked first on the introductory pages of the sites. The standard opening puts sex first and age second, on a typical introductory page taking this form: "I'm a: [Woman/Man] Seeking a: [Woman/Man] From: [age] To: [age]." 110 In addition, mainstream sites require participants to seek only men or only women, thereby structurally erasing the possibility of bisexuality. ${ }^{111}$ As with race, most sites do not otherwise try to force parties to conform to specific norms of intimate discrimination in their choice of partners. Nonetheless, the sites' insistence that participants identify their own sex (and sometimes race) requires participants to be subject to searching along these axes of identity and suggests the significance of these traits for participants' mate choices. Moreover, one mainstream site - eHarmony - allows only cross-sex seeking, directly demonstrating the sex heterogamy norm. ${ }^{112}$ Given that participants can sort themselves according to what sex they are seeking and thus avoid contacting or being contacted by members of a sex they do not desire, it is striking that a major site would limit its customers in this way. ${ }^{113}$ Perhaps an even more

\footnotetext{
109 Such factors include how many people have these desires while in monogamous relationships with opposite-sex partners, and how many have desires toward other people of the opposite sex that they forgo acting upon, as well as how many people identify as bisexual.

110 True.com, http://www.true.com (last visited Feb. 8, 2009); see also, e.g., websites cited supra note 57 .

111 Cf. Kenji Yoshino, The Epistemic Contract of Bisexual Erasure, 52 STAN. L. REv. 353 (2000) [hereinafter Yoshino, Bisexual Erasure]. Mate I used to be the exception in this group. As of March 20, 2008, Mate I allowed participants to be seeking a "man," "woman," or "either." By December 2008 , however, the site allowed only monosexual options.

112 As of February 8, 2009, the options on eHarmony are "I'm a Man seeking a woman" or "I'm a Woman seeking a man."

113 Lawsuits have been filed against eHarmony on this basis by a private plaintiff in California and by the Division on Civil Rights in New Jersey. See Bob Egelko, eHarmony Accused of Discrimination, S.F. CHRON., June 2, 2007 , at $\mathrm{B}_{2}$; News Release, State of New Jersey, Division on Civil Rights Announces Settlement with eHarmony, Inc. (Nov. 19, 2008), available at http:// www.nj.gov/oag/newsreleaseso8/pr2008I I I ga.html. On November I9, 2008, eHarmony settled the suit in New Jersey, promising to create a same-sex matching service by March 3I, 2009, though continuing to deny any violation of state law. McKinley v. eHarmony.com, No. $\mathrm{PQ}_{2} 7 \mathrm{IB}-$ or846 (N.J. Dep't of Law and Pub. Safety, Nov. I2, 2008) (settlement agreement), available at http://www.nj.gov/oag/newsreleaseso8/pr2008 I I I9a-eHarmony-SA.pdf. As of this writing, the California case was still proceeding to trial; the defendant argues that the case is now moot in light of the New Jersey settlement, but the plaintiffs disagree, citing the compensatory damages claim. See Debra Cassens Weiss, eHarmony Lawyer Says Calif. Gay Bias Suit is Moot; Plaintiffs Disagree, A.B.A. J., Nov. 20, 2008, available at http://www.abajournal.com/news/eharmony_ lawyer_says_calif._bias_suit_is_moot_plaintiffs_disagree/. Though not reaching the merits, a recent decision on a site for roommates may have helped pave the way for dating site lawsuits of this kind. See Fair Hous. Council v. Roommates.com, 52 I F.3d II57 (9th Cir. 2008) (en banc) (holding that the Communications Decency Act does not shield Roommates.com from a Fair
} 
striking indication of the persistence of the sex heterogamy norm is the fact that a niche site for singles with elite educations (the so-called Right Stuff) - which sidesteps the intimate norms around race by declining even to invite participants to indicate racial preferences permits only cross-sex searching. ${ }^{114}$

3. Literature. - Cultural texts depicting the pressures toward sex heterogamy are legion and familiar. ${ }^{115}$ Rather than examining one of those texts, therefore, this section highlights a source that parodies the sex heterogamy norm through the provocative lens of gender. Normative heterogamy also applies to some extent to gender, in the sense of masculine and feminine, as well as to sex, in the sense of male and female. Within the normative heterogamy of heterosexual expectations, masculine is expected to want feminine and feminine masculine. A few years ago, a parody of the alternative gender pairing - and thus of the heterogamy norm for sex - appeared in the New Yorker. Lampooning what the author calls "Samish-Sex Marriage," the piece suggests a new horizon for the opponents of same-sex marriage: those male-female couples composed of masculine wives and feminine husbands, whose genders come close enough to the middle or the other side as to approximate same-gender marriage."16 "Because my feeling is," the author writes, "when God made man and woman He had something very specific in mind. It goes without saying that $\mathrm{He}$ did not want men marrying men, or women marrying women, but also what He did not want, in my view, was feminine men marrying masculine women." 117 The piece was parody - mainly of the same-sex marriage debate and, especially, the anti-gay marriage position — but it also comically depicted another serious phenomenon. Gender expectations in dating and marriage still arguably favor divergent roles and traits, and within male-female dating, some of these still imply a cer-

Housing Act claim, because the CDA's safe harbor provision does not apply to content that internet service providers "develop" in whole or in part, and Roommates.com develops content by requiring users to create a profile that identifies their sex, sexual orientation, and parental status and then matching only those who fit each other's criteria); but cf. Chicago Lawyers' Comm. for Civil Rights Under Law, Inc. v. Craigslist, Inc., 5 I 9 F.3d 666 (7th Cir. 2008).

114 The Right Stuff bills itself as the "Ivy League of Dating" and checks out asserted academic credentials to make sure members actually attended one of the elite schools on their list. See The Right Stuff, Schools, http://www.rightstuffdating.com/v_schools.cfm (last visited Feb. 8, 2009); The Right Stuff, How It Works, http://www.rightstuffdating.com/v_how_it_works.cfm (last visited Feb. 8, 2009) ("To join, ... write a short profile of yourself, which will be seen by all members of the opposite sex."); infra notes 208-I I and accompanying text.

115 See, e.g., David Leavitt, My Marriage to Vengeance, in A Place I've Never Been 35,

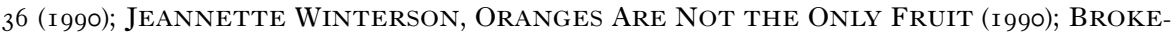
BACK Mountain (Paramount Pictures 2005) (based on Annie Proulx, Brokeback Mountain, New Yorker, Oct. I3, I997, at 74); Lost AND Delirious (Dummett Films \& Cité-Amerique 200I).

116 George Saunders, My Amendment, New Yorker, Mar. 8, 2004, at 38, 38.

117 Id. 
tain inequality of partners. For example, research on male-female speed dating suggests that even a highly educated man who considers intelligence a plus in women generally does not want a woman whom he believes is more ambitious or intelligent than he is, whereas the woman prefers more intelligence in a man, even if that means he is more ambitious or intelligent than she. ${ }^{118}$

\section{E. Intimate Norms Beyond the Intimate Sphere}

The norms from the intimate domain - of heterogamy, homogamy, and desexualization - extend beyond the bedroom walls into other domains. For instance, these norms affect the ways that courts understand claims of employment discrimination. Specifically, they shape what scenarios courts recognize as discrimination in the workplace by fueling misleading "core stories," Linda Krieger's term for societal stories that form a kind of template against which we compare all instances of discrimination. ${ }^{119}$ Krieger focuses on the problematic role of discriminatory intent in our core stories of employment discrimination, an aspect of the antidiscrimination project that I also hope to unsettle through this consideration of discrimination. ${ }^{120}$ But core stories have other features as well, beyond the presence or absence of intent. This section begins by introducing the idea of core stories and then sketches the significance of the intimate discrimination norms for our core stories of employment discrimination in the realms of sex, race, and disability. Core stories are important to identify because they deflect courts' attention away from forms of discrimination that do not fit the anticipated story.

I. Three Core Stories of Discrimination. - The question "which is worse?", when asked about forms of discrimination, is typically best avoided. It threatens to create turf wars and hierarchies among incommensurable experiences, and thus in many contexts, it is misguided at best, and deeply divisive at worst. ${ }^{121}$ But the question can be useful pedagogically, and I therefore ask my employment discrimination students: "Is it worse to be an employee categorically excluded by a discriminating employer, or to be an employee retained, kept within the fold, but relegated to a particular demeaning position?"

\footnotetext{
118 See Raymond Fisman et al., Gender Differences in Mate Selection: Evidence from a Speed Dating Experiment, I2 I Q.J. ECON. 673, 684-85 (2006).

119 Krieger explains that the "core stories" that courts create "structur[e] the interpretation of experience and provid[e] the authors and audiences of future stories with commonly recognized plots, symbols, themes, and characters." Krieger, supra note 5, at i i66.

120 See infra Parts II-III, pp. I340-79.

121 Its most obvious version is one that was commonly asked during the 2008 Democratic presidential primary: which is worse, race discrimination or sex discrimination?
} 
The question arises in our discussion of an early Title VII case, Slack v. Havens, ${ }^{122}$ in which an employer ordered three African American women to do heavy cleanup of a worksite, when their jobs were supposed to entail only light cleanup of their individual workstations. The significance of race to the employer's assignment of tasks seemed fairly clear from the employer's decision that day to transfer out of the department the one white employee and to transfer back in a black employee who had been temporarily assigned elsewhere. The role of race was then made explicit, in response to the women's insistence that this wasn't part of their jobs, by the supervisor's comments that "Colored folks are hired to clean because they clean better" and "Colored people should stay in their places." 123

Contrast the scenario in Slack with what we might call Clack, a hypothetical case in which the supervisor simply fires the women because the new plant manager does not like black people. Which is worse from the women's perspective? Which employee would you prefer to be?

The question of course has no simple answer, if it has an answer at all, but asking the question invites the students to elaborate what is deeply troubling about each scenario. The students raise points like the fact that the Slack employees at least have a choice: they get to choose whether to stay on the job. Moreover, they still have a job, and a paycheck, a material reality easy to overlook amidst discussions of stigma and contact and integration. On the other hand, some students suggest that the excluded employees may face less of a dignity harm in their exclusion. Those who are forced out may be spurred to develop their own businesses and self-sustaining enterprises. Their lack of choice may help propel them to independence and eventually to real equality with their former employers.

A student will eventually point out that in our contemporary world, our core story for race discrimination looks more like Clack, in which the employer just does not like people of another type and wants to avoid them at all costs, whereas our core story for sex discrimination looks more like Slack, in which the employer is the kind of man who does not necessarily dislike the other group, and does not want to avoid them; on the contrary, he wants women near him, but only in certain roles. The student may recall Mary Becker's point:

[The] desire for subordination, rather than aversion, may be a greater part of discrimination against women than against racial minorities. Sexist men do not, as a general rule, try to avoid all contact with women. On the contrary, they desire contact in certain subordinating forms, such as

1227 Fair Empl. Prac. Cas. (BNA) 885 (S.D. Cal. I973).

123 Id. at $886-87$ (internal quotation marks omitted). 
having women as secretaries and dependent wives. In contrast, many whites would prefer to avoid all contact with African Americans, although other whites . . . enjoy subordinating relationships with people of color. ${ }^{124}$

Of course, as Becker suggests, both kinds of stories are present for both race and sex and, I would add, for disability. (To imagine just one scenario in which a nondisabled discriminator would want disabled people around and in a particular role, think of the Maxim reader wanting someone to laugh at, someone around whom to feel masculine and sexually successful. ${ }^{125}$ ) But core stories tend to be those that dominate the imagination. They can operate like an eclipse, making it hard to see other types. This story of Slack invites us to consider how the intimate discrimination lens of this Article illuminates our core stories - and courts' associated difficulties seeing other stories across sex, race, and disability. The tripartite distinction in the intimate domain among normative heterogamy (Slack), homogamy (Clack), and desexualization (an even more isolating story than Clack) turns out to help shape courts' (mis)understanding of workplace dynamics, as this section explains.

2. Heterogamy: Intimate Hievarchy, or, Hold Them Close but Keep Them in a Role. - Our intimate norm about sex/gender proscribes within-group pairing; it works against men pairing with men and women with women in the intimate domain. But normative heterogamy also prescribes putting men and women together and keeping them together. In a sense, it is an integrative norm, one that requires intensely intimate forms of togetherness between members of different groups, a point that some anti-same-sex marriage briefs have played upon by using the language of equality and integration. ${ }^{126}$ But normative heterogamy does not mean being together in all ways. Rather, it typically prescribes holding women close, but keeping them in a role. It is, in this way, the Slack version of events, more than the Clack version. Thus, by one account, when women begin to enter the workforce in traditionally male spheres, the men try to turn them into mistresses, thus replacing them in the private sphere. Hence the familiar story of sexual harassment: the sexualizing of women in the workplace.

\footnotetext{
124 Becker, supra note 34, at I668.

125 See supra section I.C.3, pp. I327-30 (discussing a joke from Maxim).

126 See, e.g., Brief Amicus Curiae by the Roman Catholic Diocese of Burlington Vermont et al. at IO-I I, Baker v. State, 744 A.2d 864 (Vt. I999) (No. 98-32) ("Proponents of homosexual marriage often present their position as advancing the equality of the sexes. Precisely the opposite is true. Homosexual marriage embodies a vision of sexual segregation which denies the equal value and indispensability of each sex to marriage... The Court should not require the state, in the name of equality, to publicly affirm and legally sponsor relationships which fundamentally contradict the vital ethos of gender integration." Id. at I (citation omitted)); see also Brief of Appellee State of Vermont at 87, Baker (No. 98-32).
} 
But men's desire to maintain that role-based relation translates not only into sexualization; it can also translate into wanting to keep women out of the workplaces traditionally reserved for men. Integrating those environments alters the expected roles. It threatens to change not only those workplaces, but the relations between men and women in their intimate spheres. If women operate as equals in male public worlds, then perhaps they won't accept being something less than equals in private heterogamous intimate worlds (or perhaps they won't accept those worlds at all). Hence the story of sexual harassment that Vicki Schultz has made prominent: men use sexuality and sexualization (as well as other work-undermining strategies) to try to push women out of jobs, not to keep them in and use them for sex.

As Schultz has shown, courts often do not see the nonsexual forms of harassment as harassment. ${ }^{127}$ Normative heterogamy is assumed to be such a strong social force that courts expect that intimate pull between men and women to be ever present, and thus courts see the mating story above (and often instead of) all else. When the undermining is based on competence, when the goal is exclusion and not sexual congress, then courts' perceptive abilities fail them. The norm of the intimate domain thus both contributes to one form of discrimination in the employment domain and skews courts' perception so they can see only that form of discrimination.

3. Homogamy: Dissociation, or, the Illusion of Separate but Equal. - For race, the sexual norm is homogamy. The expectation is that people desire and wed within their own group. But this assumption is not a purely symmetrical one. Rather, those on the bottom are generally expected to want those on the top; most notably, black men are expected to want white women. ${ }^{128}$ The dominant group is expected, however, to want to disassociate from other races. In the workplace, this intimate norm may help to underpin the core story of race discrimination.

The expectation of normative homogamy with regard to race may translate into difficulties for courts in seeing subtler forms of bias that involve what Becker calls "the desire to subordinate,"129 rather than the desire to exclude or simple aversion. As noted earlier, Epstein writes, in theorizing about workplace dynamics, that "[l]ike attracts

127 Vicki Schultz, Reconceptualizing Sexual Harassment, I07 YALE L.J. I683 (I998).

128 See, e.g., supra note $5 \mathrm{I}$. The fact that subordinate group members are expected to want to violate the norms of homogamy does not mean they actually want to. (Think here, for example, of the reasons discussed in the Bell story, supra section I.B.3, pp. I323-24.) As to why more black men marry white women than black women marry white men, this is a complicated question subject to multiple explanations, as discussed in section I.B.I(c), pp. I320-2 I.

129 Becker, supra note 34, at I667. 
like."130 That is certainly the assumption in the intimate domain with regard to race. Whereas courts are keen to understand intergroup relations between men and women in the workplace as all about (male) desire - rather than exclusion - courts looking at race discrimination cases may fail to see complicated dynamics of role-based racial discrimination because they are expecting exclusion. Unless the case presents strongly racialized language and direct comparator evidence, as in Slack, courts may have difficulty in appreciating as discrimination the role-based demands that permit employees to remain so long as they perform or cover their race in particular ways. ${ }^{131}$

4. Desexualization: Isolation, or, Not Even the Illusion of Separate but Equal. - Just as normative desexualization is about utter exclusion of disabled people from the intimate realm - not just relegation or segregation to pairing only within one's group — so our core story of disability employment discrimination is about utter exclusion, that is, isolation. The history of institutionalization of people with disabilities makes its way into our current thinking about disability, in the intimate domain and elsewhere. Normative desexualization entails an idea of disability that involves complete isolation - the man who has never been kissed or hugged, much less had sex - the kind of person who lives in the isolation of an institution. (Of course, institutions are full of people, but I think in the popular imagination they involve being wrenched from one's friends and family, and thus from any kind of social world.) Even noninstitutional living for disabled people seems to imply by its name - "independent living" — a kind of isolated living, all alone, independent. ${ }^{132}$

In the workplace context, this notion of total social isolation fuels a misleading core story in two ways. First, it may contribute to, and rationalize, the bind of the disabled ADA plaintiff in having to show both that she is really "substantially limit[ed in a]... major life activit[y]"133 and that she is also otherwise qualified for the job. ${ }^{134}$ While this is certainly a bind for the plaintiff, it is not, I think, the paradox that it seems. If the image of a disabled person is of a person intensely and inherently limited — so limited that she must be isolated and institutionalized - then of course it is difficult to show that one is disabled and yet capable of participating in the workplace.

\footnotetext{
130 EPSTEIN, supra note 33, at 68 (internal quotation marks omitted).

131 See Devon W. Carbado \& Mitu Gulati, Acting White? (unpublished manuscript, on file with the Harvard Law School Library), on performing; and Kenji Yoshino, Covering, I I I YALE L.J. 769, 879-905 (2002), on covering.

132 I thank Jill Anderson for the point about the term "independent living."

13342 U.S.C. § I $2 \mathrm{IO} 2(2)(2000)$.

134 Id. $\$ \S$ I I I 2(a), I 2 I I I(8). On this bind, see, for example, Chai Feldblum, Definition of Disability Under Federal Anti-Discrimination Law: What Happened? Why? And What Can We Do About It?, 2I BERKELEY J. EMP. \& LAB. L. 9I, I4I-57 (2000).
} 
In addition, an idea of sexual and social isolation for disabled people may undergird courts' letting employers off the hook. If isolation is the paradigm of disability, then the employer who already hired the disabled person, deeming that person capable of working and of participating in the work world, must not be prejudiced. Given that discrimination lawsuits are, for various reasons, rarely failure-to-hire cases, ${ }^{135}$ the employer in such cases has therefore already demonstrated its enlightened - even superhuman - perspective on disability, by hiring a disabled person and thus defying this core story of isolation. This may help to explain why ADA plaintiffs have such a low success rate. ${ }^{136}$ Judge Posner has been criticized for saying that the word "stigmatizing" is "merely an epithet" when applied to separate but equal facilities under the ADA. ${ }^{137}$ Though the criticism of Judge Posner's normative or legal conclusion may be apt, as a descriptive matter he may be correctly intuiting contemporary norms. To have separate but equal facilities, to suffer merely segregation rather than isolation, is still viewed as a major advance for disabled people in the work world. Courts may therefore not be able to see beyond this core story of discrimination as utter isolation, and thus they may fail to recognize other forms of workplace discrimination in this context. In these ways, we see how the norms of intimate discrimination operate in the domain of the workplace to frame what forms of discrimination courts are able to see and thus to vindicate.

\section{ON INDIVIDUAL DIFFERENTIATION}

Is intimate discrimination bad? Might it be neutral, or even good? What does it mean to base our desires, our intimate decisions, on identity traits that cannot, by law, form the basis for decisions in other domains like employment? Then again, what would it mean not to

135 See, e.g., John J. Donohue III \& Peter Siegelman, The Changing Nature of Employment Discrimination Litigation, 43 STAN. L. REV. 983, I0I5-I9 (I99I); Michael J. Yelnosky, Filling an Enforcement Void: Using Testers To Uncover and Remedy Discrimination in Hiring for LowerSkilled, Entry-Level Jobs, 26 U. MiCH. J.L. REFORM 403, 4I I \& n.23 (I993).

136 See, e.g., Ruth Colker, Winning and Losing Under the Americans with Disabilities Act, 62 OHIO ST. L.J. 239, 257 (200I).

137 Judge Posner wrote, of a plaintiff's complaint about a failure to make a $\$$ I50 accommodation to lower a kitchen sink so the plaintiff could wash out her coffee cup in the kitchen rather than the bathroom, as follows:

[W] do not think an employer has a duty to expend even modest amounts of money to bring about an absolute identity in working conditions between disabled and nondisabled workers. The creation of such a duty would be the inevitable consequence of deeming a failure to achieve identical conditions "stigmatizing." That is merely an epithet.

Vande Zande v. Wis. Dep't of Admin., 44 F.3d 538, 546 (7th Cir. 1995). For criticism, see, for example, Cass R. Sunstein, Cost-Benefit Analysis Without Analyzing Costs or Benefits: Reasonable Accommodation, Balancing, and Stigmatic Harms, 74 U. CHI. L. REV. I895 (2007). 
discriminate on the basis of race, disability, or sex in the erotic and romantic realms?

This Part examines intimate discrimination at the individual level to try to address these questions. For purposes of this Part, then, intimate discrimination largely means intimate differentiation, that is, individuals distinguishing other individuals on the basis of these traits in the context of intimate relations. The aim here is twofold: first, to unearth and elaborate the complications of the subject, for their inherent interest; and second, to help us see why the general policy assumption in this area - that individual differentiation in the intimate realm should not be legally prohibited - is both correct and incomplete. Studying the contours of this frequently overlooked cousin to legally regulated discrimination prepares us for a discussion of what roles the state should and should not play in intimate discrimination.

\section{A. The Individual Lover's Discourse}

This section both demonstrates the complexity of intimate discrimination and explores the richness of the subject by presenting the ideas in a format that resists a simple summary. Thus, what follows is a series of observations presented as numbered propositions, from one to twelve. Some of the propositions are provocative; some may seem banal. ${ }^{138}$ These ideas are not meant to be the last word on the subject, but are meant, rather, to adumbrate the beginning of a study. The propositions start with an inquiry into the problem of intimate discrimination - asking what the trouble is here - then proceed to examine the reasons why people discriminate in the intimate domain. The list concludes with some preliminary reflections on the difficulty of determining what intimate nondiscrimination would mean at an individual level.

Speaking about intimate discrimination in general means inevitably eliding important distinctions at times - most notably, the vast differences among sex, love, marriage, dating, and desire, all of which find, albeit variously and incompletely, a place under the rubric of the intimate. ${ }^{139}$ At moments I will discuss these nuances in some detail, and at times I will breeze past them to reach other points. Likewise, the identity categories at issue operate in significantly different ways - as Part I goes some way toward showing - but this section will at times speak of the categories together, to learn from their connections, to see

\footnotetext{
138 It may well be true that "it's only by being shameless about risking the obvious that we happen into the vicinity of the transformative." EVE KOSOFSKY SEDGWICK, EPISTEMOLOGY OF THE ClOSET 22 (I990).

139 See supra note 7 (noting the complexity of the term intimacy).
} 
their contrasts more starkly, or again to reach further points without submitting to endless detours and disclaimers.

I. Some intimate discrimination tracks discrimination that we find objectionable in other domains. - As Charles Lawrence noted two decades ago, one of the signs of the unconscious significance of racism is the way it takes sexual forms, in "[t]he preoccupation among racially prejudiced people with sexual matters in race relations" and by the designation of outgroups as "dirty or smelly or both." 140 In this way, the white person whose online dating profile says that she would consider dating others of every race but African American may well have something against that particular group. ${ }^{141}$ Demographers tend to measure a country's racial integrative success by the levels of interracial marriage in that country, ${ }^{142}$ and while there may be important, and sometimes benign, reasons for in-group affiliation (of which more later), extremely low rates of intermarriage in a country plausibly signify the presence of what we commonly understand to be racial animus. Relatedly, rates of marriage and sexual activity for disabled people are lower than for nondisabled people, ${ }^{143}$ for what is surely a complicated set of reasons, among them the stigma that discredits disabled people as not fully human, and disgust at disabled bodies or minds. ${ }^{144}$

Anecdotally, it is interesting to note that even those highly critical of what they term the "politically correct" project of thinking in terms of discrimination may invoke an individual's personal relationships as a sign of their deeper politics of integration. Thus the theorist Slavoj Zizek said in a recent talk, as an assumed indictment of political correctness and as if punctuating the end of a conversation rather than beginning one, "All the big multiculturalists I know have no black friends." 145 It is interesting to consider what it would mean to think

140 Charles R. Lawrence III, The Id, the Ego, and Equal Protection: Reckoning with Unconscious Racism, 39 STAN. L. REV. 3I 7, 334 \& n.70 (I987).

141 As Randall Kennedy points out, with personal ads, as with other racial discrimination, "[w]e see the racial signals but not the motives behind them." KENNEDY, supra note Io, at 29. In response to Kennedy's written queries, some authors of personal ads explained their motives, including the "first person who answered," who "gave racist reasons for including whiteness among the traits he desired. He believed that whites — or, to use his terminology, 'Aryans' - were superior to others and needed to band together to combat what he saw as the worldwide antiwhite conspiracy." $I d$. at 30 .

142 See, e.g., Lewis, Yancey \& Bletzer, supra note 45, at 60-6I (considering the United States's interracial marriage rates).

143 See supra section I.C.I, pp. I325-26.

144 See, e.g., SHAKespeARE, GILlESPIE-SELls \& DAVIES, supra note 73.

145 Slavoj Zizek, Remarks at the Critical Legal Conference at Birkbeck College, University of London (Sept. 2007) 
this sort of commonplace accusation, not in the realm of friendship, but in a sexual realm, where it is so rarely made. ${ }^{146}$

2. But some forms of intimate discrimination may be not only common but also necessary for desire. - With regard to the first proposition one might ask, What about sex, as opposed to disability or race? Most people believe the sex of another is the starting point for their desire. ${ }^{147}$ That is, most people understand themselves to be monosexual rather than bisexual, so another person's maleness or femaleness is a prerequisite for desire, or at least for sexual intimacy. ${ }^{148}$ Even among many bisexuals, a partner's sex is not irrelevant. ${ }^{149}$ So if someone else's sex is often understood to be necessary to desire, might this be true, for some people, of race or disability as well? ${ }^{150}$ Then again, one might ask, how often are assumptions about desire and race or disability based in stereotypes, and if stereotypes are by definition not true in every case, then how often can race or (dis)ability be truly necessary to desire? ${ }^{151}$

3. Affirmative desire for a certain type may seem less troubling than a desire to exclude or avoid certain types or categories. - The Asian American woman who, on a dating website, checks that she specifically seeks Hispanic men, looks rather different from the same woman who checks every box but African American. Likewise, we may wonder whether the Christian person who checks every religion, including Muslim and Hindu, but declines to check Jewish, harbors anti-Semitic feelings. More broadly, categorical desexualization of disabled people may be more troubling than individual intergroup affini-

146 Of course, the norm of monogamy limits the application of Zizek's precise statement for most people. Cf. Elizabeth F. Emens, Monogamy's Law: Compulsory Monogamy and Polyamorous Existence, 29 N.Y.U. REV. L. \& SoC. CHANGE 277 (2004).

147 This is a reason cited by and to parents of intersex children in favor of genital surgery. See, e.g., Elizabeth Weil, What If It's (Sort of) a Boy and (Sort of) a Girl?, N.Y. Times, Sept. 24, 2006, $\S 6$ (Magazine), at 48,50 .

148 Of course, literature is rife with examples of people desiring people of the sex they thought they did not desire, when the other is in cross-sex disguise. Bisexual desires are apparently more common than they are acknowledged, see, e.g., Yoshino, Bisexual Erasure, supra note I I I, at 37788 , but most people nonetheless understand their desire to be, first and foremost, framed by the other's sex. The internet provides multifarious possibilities for unsettling this assumption, which may be part of why sex is always and obviously asked first on mainstream dating sites. See supra section I.D.2, pp. I332-33.

149 See infra p. I355.

150 Some of the evolutionary theories of love and desire, which aim to explain such phenomena of assortative mating, would posit biological factors as key to this kind of sorting, including along racial lines. For more on assortative mating, see infra notes $286-87$ and accompanying text. But note also that even sex for these purposes may be largely culture (gender) - the cues to biological sex - rather than sex per se, in the sense that desire typically precedes direct knowledge of another's sex organs or chromosomes (for instance). Perhaps the gender of another, his or her masculinity or femininity, is crucial.

$151 \mathrm{Cf}$. infra note $\mathrm{I} 82$. 
ties and disaffinities, such as compliance with a racial homogamy norm, since desexualization isolates rather than segregates.

4. Category-based affinities may also be controversial, however - a tension captured by the language of having a "fetish" as opposed to a "type." - So-called fetishists or devotees around certain races or disabilities or body types garner very mixed reactions. For instance, "amputee devotees" (or acrotomophiliacs), who specifically desire female amputees, ${ }^{152}$ are met with outright hostility by some amputees and other disabled people for their objectification of particular bodies and impairments. But these devotees are greeted more favorably by others, who feel that desire generally involves objectification, and that it is appealing to be desired, even or especially for that which inspires rejection or revulsion in many. ${ }^{153}$ These debates mirror features of longstanding debates among feminists and disability activists about whether and when objectification might be appealing, particularly to those who have been subjected to normative desexualization. ${ }^{154}$ Relatedly, early psychological work on cross-ability relations implied that nondisabled people who became involved with disabled people must be pathological in some way; more recent work has attempted to counter this pathologizing move with qualitative studies of nondisabled people in cross-ability relations. ${ }^{155}$

The complicated terrain of racial types, or exoticism, is elegantly captured by Phyllis Rose in her biography of Josephine Baker:

152 Per Solvang, The Amputee Body Desired: Beauty Destabilized? Disability Re-Valued?, 25 Sexuality \& Disability 5 I (2007); Ian Gregson, The Acrotomophile (or Devotee): An Amputee's Perspective (Sept. 28, 2008), http://www.amputee-online.com/amputee/acrotomophile.html.

153 See, e.g., Solvang, supra note I52; see also ShakesPeARE, GillesPie-Sells \& DAVIES, supra note 73, at I24-3I; M. Christian, Please, Take My Limbs: The Sexual Worship of Stumps, GETTINGIT.COM, Aug. 2, I999, http://www.gettingit.com/article/577 (discussing the erotics of amputee devotion, and its relationship (for some) to a desire or decision to be amputated oneself). Related debates have arisen around "fat fetishism" or "fat admirers," as possibly signaled by the removal of a pro-fat admirer "official position" statement on the site of the National Association to Advance Fat Acceptance (NAAFA). See NAT'L AsS'N To Advance FAT Acceptance, FAT ADMIRERS, available at http://www.naafaonline.com/dev2//about/Policies/FATADMIRERS. pdf (last visited Feb. 8, 2009).

154 See, e.g., Adrienne Asch \& Michelle Fine, Introduction: Beyond Pedestals to WomeN With Disabilities I, 29-30 (Michelle Fine \& Adrienne Asch eds., I988).

155 See, e.g., Maureen S. Milligan \& Aldred H. Neufeldt, Postinjury Marriage to Men with Spinal Cord Injury: Women's Perspectives on Making a Commitment, I6 SEXuality \& Disability I 7 (I998). As Milligan and Neufeldt explain, one early work offered the following "typology of individuals who are unusually attracted to disabled people, though no data was given in support of their descriptors": "walking wounded"; "would-be dictators"; "unsolicited missionaries"; "gallant gesturers." See id. at i i8 (citing Charlene Deloach \& Bobby G. Greer, Adjustment to Severe Physical Disability 95-96 (198I)). DeLoach and Greer do acknowledge an alternative nonpathological type, though very briefly. See DELOACH \& GREER, supra, at 95 ("Not included among the descriptions which follow are those valued individuals who relate well to everyone, disabled or not."). 
Compared with racism, exoticism is merely decorative and superficial. It doesn't build death camps. It doesn't exterminate. Exoticism cares mostly about its own amusement and tends to find differences of color amusing where racism finds them threatening. Exoticism is frivolous, hangs out at nightclubs, will pay anything to have the black singer or pianist sit at its table. Racism is like a poor kid who grew up needing someone to hurt. Exoticism grew up rich, and a little bored. The racist is hedged around by dangers, the exoticist by used-up toys.

If one is to be treated as a thing, one would rather be treated as a rare and pretty thing than as a disgusting or dangerous one. But that is still to be treated as a thing. ${ }^{156}$

In the rather different domain of adoption, Rachel Moran writes that adoption "agencies tend to distrust adoptive parents who express a preference for a child of a different race and commonly make extensive inquiries about their racial attitudes."157 This example from another context sets into relief the suspicion assigned to particular intimate affinities across the divides of race or disability, in contrast to the assumed normalcy of a particular desire for one's own race or of a categorical lack of desire vis-à-vis disability.

5. Moreover, certain intersections of identity categories conjure their own stereotypes and hierarchies of desirability and exclusion. For men, blackness is associated with greater masculinity, and Asianness with less. ${ }^{158}$ Russell Robinson has written eloquently about the constraints these stereotypes of desire place on dating options, particularly among gay men, and has demonstrated the presence of certain "racialized sex roles" on gay dating sites, ${ }^{159}$ specifically, the "aggressive black top" and the "submissive Asian bottom."160 These stereotypes work together with the broader cultural privileging of masculinity in men - and in many contexts, though not all, femininity in women in the intimate domain. ${ }^{161}$ As discussed earlier, the meanings of inter-

\footnotetext{
156 Phyllis Rose, Jazz Cleopatra: Josephine Baker in Her Time 44 (I989), quoted in MORAN, supra note 23, at II 5 .

157 MORAN, supra note 23, at I47; see also BARTHOLET, supra note Io, at I82.

158 Cf. Thomas \& Goff, supra note $5^{2}$.

159 Robinson, supra note 4 , at 2788.

160 Id. (internal quotation marks omitted); see also id. at 2809-18.

161 Mary Anne Case has written persuasively about the greater value placed on masculinity in both men and women in other spheres of life. Mary Anne C. Case, Disaggregating Gender from Sex and Sexual Orientation: The Effeminate Man in the Law and Feminist Jurisprudence, I05 YALE L.J. I (I995). The intimate and sexual spheres may provide the central counterexample to this phenomenon for women (though not for men), in the context of their relationships with men and sometimes women. I say "sometimes women" because butch lesbians generally do better than butch straight women in their respective status hierarchies of desire, but femmes or non-butches are nonetheless more in demand for many women seeking women. See, e.g., Christine A. Smith \& Shannon Stillman, Butch/Femme in the Personal Advertisements of Lesbians, in LESBIAN LOVE AND RELATIONSHIPS 45, 48 (Suzanna M. Rose ed., 2002) (discussing a study of lesbian personal ads in which, of the one-third of ads that specified a gender preference, more of those ads explic-
} 
racial sex for black men with white women differ markedly from those for black women with white men, in ways that may contribute to the gendered divide in black-white marriage rates. ${ }^{162}$ Some work suggests that "[ $t$ ]he only group of disabled adults in which women are more likely than men to be married is women who are labeled retarded," an anomaly scholars have attributed to the intersection of disability and gender stereotypes. ${ }^{163}$ That is, "the retarded wife may fit all too well the criteria of the 'good wife': one who is docile, passive, loyal, and dependent, not likely to show her husband up."164 Some identity intersections create categories of individuals who are relatively left out of the dating market, much as normative desexualization works to exclude people with disabilities. For instance, as discussed earlier, and as Robinson notes, interracial dating rates are higher among black men than black women, leaving black women with relatively fewer potential partners. ${ }^{165}$ Moreover, access to dating opportunities and even information may be affected by the intersection of one's identity categories, as, for example, many gay disabled people know too well. ${ }^{166}$ These are just a few of the intersections that work to create differential opportunities in dating markets. ${ }^{167}$ These examples show some of the ways that the identity contexts of intimate discrimination defines its meaning. ${ }^{168}$

itly preferred feminine women, either affirmatively or through specific "no butches" requests, whether the ads were written by women who identified as femme, butch, or neither).

162 See supra notes 50-55 and accompanying text.

163 Asch \& Fine, supra note I $54_{4}$, at I5 (citing Constantina Safilios-Rothschild, Discrimination Against Disabled Women, INT'L REHAB. REV., Feb. I977, at 4, 4).

164 Id.

165 See supra notes $46-55$ and accompanying text. Age also works with sex to help create the relatively disadvantaged category of older women.

166 See, e.g., Chelsea Whitney, Intersections in Identity: Identity Development Among Queer Women with Disabilities, 24 Sexuality \& Disability 39, 40 (2006); cf., e.g., Milk (Focus Features 2008) (portraying a young man in a wheelchair trying to figure out how to escape his parents' plans to institutionalize him for being gay).

167 A related problem is the way that certain identity intersections can leave some individuals particularly vulnerable to sexual victimization — such as African American women and disabled women - whether through pervasive ideas or circumstances of vulnerability, sexualizing stereotypes, or relative disregard by the criminal justice system. See, e.g., Kimberl[é] Crenshaw, Mapping the Margins: Intersectionality, Identity Politics, and Violence Against Women of Color, 43 STAN. L. REV. I24I, I265-82 (I99I); supra notes 23, 74 and accompanying text; see also Kenneth W. Mack, Law, Society, Identity, and the Making of the Jim Crow South: Travel and Segregation on Tennessee Railroads, I875-1905, 24 LAW \& SOC. INQUIRY 377, 387-94 (I999) (on, inter alia, the "image of the Jezebel, the sexually promiscuous black woman," id. at 389). Sexual victimization can sometimes, paradoxically, be abetted by the norm of desexualization. See infra pp. I38I-82.

168 For a thoughtful discussion of the varied meanings of interracial intimacy, depending on context, see Robert S. Chang \& Adrienne D. Davis, The Adventure(s) of Blackness in Western Culture: An Epistolary Exchange on Old and New Identity Wars, 39 U.C. DAVIS L. REv. I 189 (2006). Davis and Chang note the cultural assumption by some - their example is the arc of the film Monster's Ball - that interracial sex is inherently anti-racist, that it is "subversive of the his- 
6. Intimate discrimination has different meanings and causes depending on the type of relationship. - For instance, people will sometimes sleep with people whom they would not marry (or sometimes even date). ${ }^{169}$ A person's family, friends, and religious and other communities typically have more opportunities to express their views about more serious, and more public, relationships. Indeed, one function of weddings is surely to present the prospective spouse to one's community, to confront the views of "God and everyone." 170 Another way that the type of relationship matters to intimate discrimination concerns numerosity. That is, most people have many more friends than lovers and certainly more than they have spouses. ${ }^{171}$ So for most people, the possibilities for diverse intimates are typically broadest in friendship, less broad in dating and sex (depending on how many partners they have over time or at once), and least broad in marriage (also, however, depending on how many times they divorce and remarry). If people form lasting and exclusive relationships, as many people do or aspire to do, ${ }^{172}$ then any categorical variations among their sexual intimates come from their dating or sexual history rather than from present practices.

7. Categorical affinities for in-group members look different, and potentially more appealing, when expressed by members of subordinate groups. - Members of any group might worry that multiracialism, for instance, will lead to all of us becoming culturally "beige" rather than a more complicated and varied bunch. ${ }^{173}$ But the desire to preserve

toric racial order." Id. at I 205 . As they rightly note, the meaning of interracial sex varies widely, however, and is thus context-specific. See id. at I200-08.

169 Cf. Erica Chito Childs, Listening to the Interracial Canary: Contemporary Views on Interracial Relationships Among Blacks and Whites, 76 FORDHAM L. REV. 277 I, 2775 (2008) ("Even white college students [interviewed in the study] who said their parents did not care if they dated interracially clearly indicated that their families prefer, or in some cases demand, that they marry within their race."). A stark difference in the social meanings of black-white sex, as opposed to marriage, has a long, problematic history. See, e.g., Kevin Noble Maillard, The Multiracial Epiphany of Loving, 76 FORDHAM L. REV. 2709, 27 I2, 2724 (2008); see also supra p. I320. In the context of religion, the idea that dating against the norm may be okay but marriage is not is well captured in the (potentially offensive) phrase "shiksas are for practice." For use of the phrase (which can be purchased printed across t-shirts, baseball caps, and thongs, among other items), see Jtshirt.com, Shiksas Are for Practice, http://www.cafepress.com/www_jtshirt_com/ 3034903 (last visited Feb. 8, 2009). Shiksa is "a disparaging term for a non-Jewish girl or woman." The Free Dictionary, http://www.thefreedictionary.com/shiksa (last visited Feb. 8, 2009).

170 See infra p. I360.

$171 C f$. Emens, supra note I46, at 288-9I (discussing the norm against jealousy in friendship as opposed to in sexual relationships).

172 See id. (discussing the gap between the fantasy and the reality of monogamy).

173 See, e.g., Peggy Orenstein, Mixed Messenger, N.Y. Times, Mar. 23, 2008, § 6 (Magazine), at 9 ("Race is thrust on Hapas [multiracials] based on the shades of their skin, the shapes of their eyes, their last names. (Quick: What race is Apolo Ohno? How about Meg Tilly? Both are halfAsian.) But ethnicity, an internal sense of culture, place and heritage — that's more of a choice. 
one's culture through homogamy seems more easily separable from racism (or its equivalent) when expressed by members of subordinate groups. In his generally measured and thoughtful book Interracial Intimacies, Randall Kennedy dismisses too easily such preferences as "essentially defensive and compensatory responses to white aggression." 174 A variety of reasons might drive such politics, including wanting to create or preserve a family or a community that feels safe from a hostile world, or to signify pride in one's own subordinated community, reasons dramatized in Bell's The Last Black Hero, discussed earlier. ${ }^{175}$ Relatedly, a member of a subordinated group could want to avoid pairing with superordinate group members if assimilation means absorption into the dominant culture. ${ }^{176}$ (The difficulties of avoiding absorption into the dominant culture are well known to non-Christians - or to Christians, for that matter - trying to raise children without Christmas.) One could even imagine a version of this antiassimilationist desire that would lead a person (on a dating website) not to pick only her own (non-white) race, but instead to check every box but white. The separatist move within deaf culture is by now well known, though more for struggles over cochlear implants and who should lead Gallaudet University than the concomitant debates around out-marriage versus in-marriage. Just as there are deaf parents who resist cochlear implants for their children, though, there are deaf individuals who would prefer a deaf spouse. ${ }^{177}$

8. Members of superordinate groups may also have reasons that are not obviously related to racial animus or discomfort with disability to

Cultivating it in our children could be the difference between a Hapa Nation that's a rich, variegated brown and one that fades to beige.").

174 KENNEDY, supra note Io, at 34.

175 See generally supra section I.B, pp. I318-24. Ayres and Brown acknowledge an antisubordination justification as the only legitimate exception to their endorsement of race- and sex-blind dating, emphasizing an African American's reasonable desire to avoid the "vestiges of racism" and associated difficulties in intimate relationships, AYRES \& BROWN, supra note I2, at 35, or a woman's desire to avoid the gender stereotyping that might come more readily in a relationship to a man, or to show that "male supremacy ... is not necessary for the operation of healthy, loving relationships," $i d$. at 37 .

176 Kennedy acknowledges these reasons:

Among the most influential opponents of interracial intimacy are blacks who see it as capitulation to white dominance. Asserting that blacks need to feel a greater sense of racial obligation to themselves as a collective, that on the ground of racial kinship they ought to prefer one another to others, and that interracial intimacy constitutes a divisive diversion, significant numbers of African Americans oppose black participation in interracial dating, marriage, or adoption (especially when the others involved are white).

KENNEDY, supra note זo, at 34 . But he prefaces these words with the following explanation: "Victims of oppression are ... quite capable of hurting themselves and others through specious beliefs and mistaken actions." Id. Kennedy seems to be concerned about blacks policing other blacks' choices, however, and other comments suggest he might be more sympathetic to an individual's reasoned choice along the lines I state.

177 Cf., e.g., Thiessen \& Gregg, supra note 49 (discussing disability-based homogamy). 
prefer in-group members, although it may be difficult or impossible to separate those reasons from animus or stereotyping. - A member of a dominant group might cite any number of reasons for preferring one's own group, such as a perception of shared cultural reference points, or a feeling of being better understood, or ease of family and community acceptance, ${ }^{178}$ or worries about a harder life for one's children because of discrimination or segregation, ${ }^{179}$ or a wish for particular functional abilities in one's spouse, ${ }^{180}$ or a desire to avoid what Erving Goffman calls the "courtesy stigma" of close association with a stigmatized group member. ${ }^{181}$ Some of these may appear race- or disabilityneutral on their face, though they may ultimately be hard or impossible to distinguish cleanly from animus or especially from stereotyping, by the individual or the community. ${ }^{182}$

9. Identity categories are multifaceted; some traits or signals of a particular category might matter more or less to different people. This point may be most obvious with disability, which comprises so many different types of impairments: from deafness to blindness to mobility impairments to psychiatric or cognitive impairments, to name just a few. Types of disabilities include functional limitations (which are greater or lesser depending on the design and accessibility of the environment ${ }^{183}$ ), cosmetic variations that entail no functional limitations (such as scarring from burns ${ }^{184}$ ), and mitigated impairments (such as a heart condition corrected by a pacemaker ${ }^{185}$ ), as well as combina-

178 Cf. Note, supra note 56 , at $889-90$ (discussing the constitutional illegitimacy of adverting to social prejudice to justify state discrimination, see Palmore v. Sidoti, 466 U.S. 429 (I984), and yet the difficulty of this question as a social or moral matter).

$179 \mathrm{Cf}$. Chito Childs, supra note I69, at 2780-8I (noting the concern among black individuals interviewed on the subject of interracial relationships for "how the biracial children will fare in this racially divided world"). On the burdens on interracial families, especially housing segregation, see infra section IV.E.2, pp. I398-99.

180 Cf. infra section II.A.9, pp. I348-50.

181 ERVing Goffman, STIGMA 30 (Touchstone I986) (1963) ("In general, the tendency for a stigma to spread from the stigmatized individual to his close connections provides a reason why such relations tend either to be avoided or to be terminated, where existing.").

182 See Chito Childs, supra note I69, at 2776-77 (describing white interviewees, on the subject of interracial relationships, "den[ying] racial preference" but providing a similar set of apparently neutral reasons for "their reasons for not dating interracially"); Note, supra note 56, at 888-9I (problematizing the reasons, such as aesthetics, given for racial preferences). The accommodation step of the individual self-inquiry proposed in section II.C may go some way towards identifying the sources of - and even unsettling - these seemingly neutral reasons for some individuals; to ask, for instance, whether any changes to one's environment or community could alter one's feelings about the desirability of a partner of a particular race or disability should prompt an interrogation of the social and contextual creation of salient features of these categories.

183 See infra section III.A, pp. I366-73 (discussing the social model of disability).

18429 C.F.R. $§$ I630.2(l) (I 994) (providing the example of a "prominent facial scar or disfigurement" as a disability under the "regarded as" prong of the ADA definition).

185 Cf. Sutton v. United Air Lines, Inc., 527 U.S. 47 I (I999) (holding, in a case involving corrective lenses, that ADA plaintiffs who mitigate must be considered in their mitigated state for pur- 
tions of these. Preferences against the latter two categories seem necessarily related to stigma or stereotypes, or at least to concerns about courtesy stigma, ${ }^{186}$ whereas functional limitations might fit to varying degrees with different personalities and needs (and may also be linked to stigma). A particular individual - a pianist, say - might care tremendously about hearing in a partner, whereas a visual artist might care much less about sound than sight. A carpenter or builder who likes to drill at odd hours - or a person who snores - might see advantages to impaired hearing in a partner. A person with a mobility impairment might want a partner with great physical agility, for the flexibility of engaging in certain sexual activities or routine tasks without third-party assistance. Or the same person with a mobility impairment might desire someone who shares her impairment, for the understanding or identification or sexual freedom that inhabiting unconventional bodies brings to some. ${ }^{187}$ (Desires for in-group members among subordinated groups, such as within the deaf community, were discussed earlier as a phenomenon with relatively well known politics; ${ }^{188}$ this point instead tries to consider other kinds of reasons for particular identity-based pairings.) In addition, people may select their prospective partners in part because they intend to have biological children and, correctly or incorrectly, expect the partner's traits to be passed to the children, or expect those traits to help or hinder parenting skills. ${ }^{189}$

Seeing this point with regard to disability helps us see its relevance to race, which is of course a deeply contested category, with many possible defining elements. Throughout U.S. history, legal and social definitions of race have variously emphasized skin color, physiognomy, cultural recognition, or blood lines (variously defined). ${ }^{190}$ Any one of these could be more or less important to an individual's imprinted erotics or community and companionship needs or social milieu. Or any of these might trigger racist fantasies in a prospective partner -

poses of the definition of disability). In contrast with Sutton's narrow reading of the ADA, this Article considers disability generally to include mitigated impairments, consistent with various state statutory definitions, see, e.g., N.Y. ExEC. LAW § 292(2 I) (McKinney 2005), and with the recent revisions of the ADA (except for vision impairments), see ADA Amendments Act of 2008 , Pub. L. No. I IO-325, I 22 Stat. 3553 (codified in scattered sections of 29 and 42 U.S.C.).

186 See supra p. I348.

187 See, e.g., Rembis, supra note 79 , at 7-I2 (citing sources).

188 See supra section II.A.7, pp. I346-37.

189 Cf. Asch \& Fine, supra note I54, at 2 I ("Fears that disabled women would produce children with similar conditions (nearly always groundless since the vast majority of disability is not hereditary) have mingled with convictions that they would harm, deprive, or burden children they attempted to rear.").

190 See, e.g., Ariela J. Gross, What Blood Won't Tell (2008); IAN F. Haney López, White By Law (I996); Neil Gotanda, A Critique of "Our Constitution is Color-Blind", 44 Stan. L. REV. I (I99I). 
racist fantasies that might be a deeply disturbing reason for both partners to avoid such a relationship or, as some have written, that could become part of a cooperative, role-playing exploration or expurgation of these cultural artifacts. ${ }^{191}$

Sex might seem a cleaner category, less subject to cultural dismantling. Of course much has been written, however, about sex's complexity. Whether sex is defined by chromosomes, external or internal genitals and sex characteristics, appearance and community recognition, or self-identification is hotly disputed. ${ }^{192}$ Our categories of sexual orientation tend to assume a rather thin notion of sex, but surely our erotic selves respond to a more complicated set of signals, including how someone inhabits his or her sex, what gender role or roles the person occupies, in ways that track or defy normative expectations. (One might think here of the New Yorker piece discussed earlier. ${ }^{193}$ )

Io. It is unclear how fixed or malleable desire is. - Some people's sexual tastes change over time or in response to new encounters or new people; some people's do not. Much work in the history of sexuality is dedicated to showing that sexuality is constructed, partially or fully, by social and historical context. ${ }^{194}$ While this work shows that sexual preferences and desires change to some extent across time and culture, it does not necessarily claim that the forms sexuality takes are any less real, or any more flexible, to a given individual at a given time. ${ }^{195}$ There is also work in psychology - which terms this phenomenon "erotic plasticity" - asserting that women's desires are more malleable than men's. ${ }^{196}$ Is this plausible, and if so, is it the result of biology or

191 See, e.g., SinfiEld, supra note IоI, at 32-53; Gary Fisher, Journals and Notebooks, in GARY IN YOUR POCKET i I 9, 234-38 (Eve Kosofsky Sedgwick ed., I996).

192 See generally AnNe FAusto-STERling, SEXING The Body: Gender Politics AND the Construction of Sexuality (2000); Noa Ben-Asher, The Necessity of Sex Change: A Struggle for Intersex and Transsex Liberties, 29 HARV. J.L. \& GENDER 5 I (2006); Dean Spade, Documenting Gender, 59 HASTINGS L.J. 73I (2008).

193 See supra section I.D.3, pp. I333-34.

194 See, e.g., Michel Foucault, The History of Sexuality: An Introduction (Robert Hurley trans., I990); SEDGWICK, supra note I38; David M. Halperin, Is There a History of Sexuality?, in The Lesbian AND Gay Studies ReAder 4I6 (Henry Abelove et al. eds., I993); Mary McIntosh, The Homosexual Role, i6 Soc. PROBS. I82 (I968); Randolph Trumbach, London's Sodomites: Homosexual Behavior and Western Culture in the Eighteenth Century, I I J. SOC. HIST. I (I 977 ).

195 See, e.g., Janet E. Halley, Sexual Orientation and the Politics of Biology: A Critique of the Argument from Immutability, 46 STAN. L. REV. 503, 552-53 (I994) (distinguishing types of constructivism and noting that "it is possible for a constructivist to claim that sexual-orientation identity is mutable across the range of human possibility, without making the distinct claim that it is mutable in a given person, or even in a given society or era").

196 See, e.g., Roy F. Baumeister, Gender Differences in Erotic Plasticity: The Female Sex Drive As Socially Flexible and Responsive, I26 PSYChOL. Bull. 347 (2000); see also LISA M. DIAMOND, SeXual Fluidity: Understanding Women's LOVE AND DeSiRE (2008). On debates about the malleability of desire more generally, see Edward Stein, Born That Way? Not a Choice?: Problems with Biological and Psychological Arguments for Gay Rights I2-13, 30-3I 
something more cultural? Is it the result of subordination, of women's not having their desires matter so much as men's, or is it a sign of greater attunement to the range of sexual possibility or of desirability?197 Some people also discover or realize a new sexual orientation later in life to the surprise - or sometimes not - of their friends. But we commonly understand a person's "sexual orientation" with regard to sex to remain the same over time, even if it is not always realized. (In contrast, people's age-related desires are expected to shift over time, to get older as they get older. ${ }^{198}$ )

Thus, desires might sometimes appear to change because, in fact, the desirer was previously mistaken about his desire or hiding it from others. ${ }^{199}$ Desires may also change because experience exposes the desirer to real people whom she would not have anticipated liking in the abstract. If a person of race $X$ grew up in a racially homogeneous community, she might think she could never desire someone of race $Y$; later life events might nonetheless bring her into contact with people of race $Y$ and change that feeling. (The assumption here is not that everyone's preferences would change with such exposure, but that some would.) In this way, desires may be somewhat endogenous to an individual's social architecture.

Relatedly, though people with disabilities are often portrayed as asexual, ${ }^{200}$ what is assumed to be true of the able-bodied person whose able-bodied partner becomes disabled? Is his or her desire imagined to leave with that transformation? It might be assumed that there is some sociobiological or essential aversion to pairing with a disabled

(Cardozo School of Law, Jacob Burns Inst. For Advanced Legal Studies, Working Paper No. 223) available at http://papers.ssrn.com/sol $3 /$ papers.cfm?abstract_id= I I 04538 .

197 See Diamond, supra note I96, at 9 (contesting the former argument). For further discussion, see Elizabeth F. Emens, Adaptive Desires (July 2008) (unpublished manuscript, on file with the Harvard Law School Library).

198 It is not pedophilia for an eleven-year-old to fancy another eleven-year-old, but it is different if a forty-year-old fancies an eleven-year-old. Indeed, the increasing age of a desired object over time is what makes age homogamy possible for most people. Note, though, the typical imbalances in the age norms - it is entirely acceptable, or even expected, for men to desire younger women, and for women to desire older men; even large age gaps in that direction draw fewer looks than the reverse. Commercial dating sites reflect the complicated status of age homogamy: the movement has been toward greater homogamy, though with a remaining assumption that men in straight pairings will be slightly older. One can see this, for example, in the age brackets invited to commercial "speed dating" events, which are for, say, "women 23-32, men 25-35" or "women 29-39, men 3I-42," in which the men are two to three years older in each pairing. New York Easydates, Upcoming Speed Dating Events in the New York, Manhattan, and Surrounding Area [sic], http://www.nyeasydates.com/events.php (last visited Feb. 8, 2009).

199 In addition, proponents of wider recognition of bisexuality as an identity category sometimes claim that such flips, from straight to gay, or the reverse, reflect ongoing mistakes about identity because more people evince bisexual desires than embrace bisexual identities. See, e.g., Yoshino, Bisexual Erasure, supra note i I I.

200 See supra section I.C, pp. I325-30. 
person, if humans are assumed to possess some eugenic aspect to their desires. $^{201}$ But Harlan Hahn has written eloquently of the historic associations between disability and erotic revelry. ${ }^{202}$ And lest one imagine that only disability advocates think impairment can be beautiful, it is worth remembering Edmund Burke on how much more beautiful women are when flawed:

There is another notion current...; that Perfection is the constituent cause of beauty. . . . But in these, so far is perfection, considered as such, from being the cause of beauty; that this quality, where it is highest in the female sex, almost always carries with it an idea of weakness and imperfection. Women are very sensible of this; for which reason, they learn to lisp, to totter in their walk, to counterfeit weakness, and even sickness. In all this, they are guided by nature. Beauty in distress is much the most affecting beauty. ${ }^{203}$

In Burke's rendering, a minimal level of impairment is an attractive part of femininity.

Setting aside the complications, of which there are many, we can observe that sexual orientation (in the sense of the sex someone desires) is generally assumed to be more fixed and less malleable, at the level of individual control, than is desire related to race or (dis)ability. ${ }^{204}$ This is partially reflected in the differences across categories in whether we have names for those who violate or comply with the norms of intimate discrimination. Mainstream English has names in a strong sense for those who desire within their own sex (homosexuals and bisexuals) and for those who desire across sex (heterosexuals); in a much weaker sense for those who desire across race (miscegenator or miscegenist) and not for those who desire within race (the normative choice); and not much for those who desire across disability (specific disability fetishists, such as the amputee fetishist mentioned above, might be an exception) and not at all for those who desire within disability or ability. ${ }^{205}$

II. To be rejected for one's identity category may be especially painful; however, for others to signal their preferred type may also be especially useful in the intimate domain. - Given the emotion surrounding intimacy for many people, it is unsurprising that intimate re-

201 But cf. supra note 49 (citing work on disability-based homogamy).

202 See Harlan Hahn, Can Disability Be Beautiful?, Soc. POL., Winter 1988, at 26, 27-29 (I988).

203 Edmund Burke, A Philosophical Enquiry into the Origin OF OUR IDEAs of THE Sublime AND BEAUTIFUl 84 (Dover 2008) (I759).

$204 C f$. infra p. I389. This is not to say that sexual orientation is "essential" rather than "constructed." See supra notes I $94-95$ and accompanying text.

205 Under race, there is also the term "nigger lover," see supra note 65 (discussing a recent employment-discrimination case involving the term), though arguably this offensive term often refers as much to friendship and simple social affiliation as to anything romantic. 
jection related to one's salient identity traits is often described in poignant terms. In the words of Ricardo Pau-Llosa:

With the Anglo woman, you are reminded of your exile not just from Cuba but from effortless cultural participation of any kind. . . Whether I dated unapologetically philistine cubanas or gringas out to prove (and therefore disprove) their 'open-mindedness,' it has been in matters of love where I have felt the pain of double exile the strongest. ${ }^{206}$

In recent years, as single works and then volumes have emerged on disability and sexuality, the pain of desexualization and related disappointments emerges as a persistent theme. ${ }^{207}$

Yet people's explicit articulation of their dating preferences as to race, (dis)ability, and sex may be efficient for — or even, in some cases, appreciated by - prospective mates (and non-mates). Gays and lesbians, for example, have long understood the utility of creating distinctive spaces for gay socializing; even in the absence of a need to avoid detection or violence, queer-only spaces save time and energy, not to mention needless rejection.

Relatedly, the niche website The Right Stuff, for straight-seeking elite-educated folks, asks members to include their age, religion, and religious preference in their (otherwise freeform) short profile. ${ }^{208}$ While members must pay to obtain other people's longer bios, this short profile is available for free. The suggestion to reveal religious preference at the first stage is presumably trying to save members the money (and trouble) of buying profiles of others whose religious preferences might categorically exclude them. By contrast, the site nowhere asks members to state race preferences - and also waits until the long pay-per-view profile to ask for a member's own race, "if relevant to you" - likely reflecting heightened sensitivity surrounding race issues among those with elite education. ${ }^{209}$ As others have noted, while race is often visible, racism is not. ${ }^{210}$ For that reason, some might even wish that preferences in this domain were made more explicit, so that mismatches could be avoided. ${ }^{211}$

206 Ricardo Pau-Llosa, Romancing the Exiliado, in Muy Macho: Latino Men Confront Their MANHOOD i i I, I23 (Ray González ed., paperback ed. I996).

207 E.g., BAER, supra note 79, at 22; KROLL \& KleIN, supra note 79, at I5-22; SHAKESPEARE, GILLESPIE-SELlS \& DAVIES, supra note 73; see also Mason-Lovering, supra note 85.

208 The Right Stuff, New Membership Form, http://secure.rightstuffdating.com/forms.cfm (last visited Feb. 8, 2009). As noted earlier, The Right Stuff refuses to allow same-sex searching, which may open it up to a lawsuit akin to that filed against eHarmony. See supra pp. 1332-33.

209 The Right Stuff, supra note 208 . Of course, participants can choose to state a race preference in the open form sections of the short or long profile. In the short profile, they may also opt to state their race or to include a photo, which may permit some assumptions about race.

210 E.g., Kenji Yoshino, Assimilationist Bias in Equal Protection: The Visibility Presumption and the Case of "Don't Ask, Don't Tell", io8 YaLe L.J. 485, 525-27 (I998).

211 Of course, there are also many reasons why parties on a dating site might not want to state racial preferences even if they have them, including (I) not wanting to acknowledge the preference 
Not knowing about another's racial preferences can have unfortunate consequences in the public sphere of, for instance, employment, as it can make it harder to avoid employers or coworkers who harbor hostility to one's race. In the workplace, however, one might choose to live with subtle antipathy, if other factors (for example, salary) sufficiently counterbalance it. Such a tradeoff is harder (though certainly not impossible) to imagine in the romantic arena, because interaction between the partners is the essence of the relationship. Explicit articulation of categorical preferences and aversions thus may be particularly welcome in the intimate domain, because it allows those whose category is not desired to avoid wasting time and emotion on unappealing or fruitless interactions. Moreover, it may at times be preferable to understand accurately any such rejections as categorical, rather than speculating about one's attractiveness as a mate in some more individualized way. While categorical rejections - disparate treatment in other domains are sometimes assumed to be more painful for victims than disparate impact, ${ }^{212}$ this seems far from clear in the intimate domain, as a categorical rejection may make it easier to dislike or blame the other party in some contexts, rather than doubting oneself. $^{213}$ That said, as with employment, we might wish that deciding what trades are worthwhile could be left up to the one who would be rejected; if the prospect of any partner is scarce, some partner - even one with some issues around the other's identity - may be preferable to none. Or at least some individuals may feel that way, while others will not, making it hard to settle on a general rule in this sphere. ${ }^{214}$

I2. It is not clear what intimate nondiscrimination would mean. - Would it be intimate nondiscrimination to claim not to notice someone's race or disability (or even sex)? In antidiscrimination law, metaphors of "color-blindness" and "sex-blindness" represent one common understanding of antidiscrimination - the model sometimes

to oneself; (2) not wanting to be thought by others as racist or narrow-minded; and (3) not wanting to send appealing signals to prospective mates who are generally racist.

212 E.g., Jeremy Waldron, Indirect Discrimination, in EQUALITy AND Discrimination 93, 95 (Stephen Guest \& Alan Milne eds., I985) ("There is a sense in which harm suffered through action motivated by prejudice is felt more keenly and resented more deeply than superficially identical harm suffered through action that was not consciously racist or sexist.").

213 I suspect this depends in part on whether one's surrounding community, and associated norms, would support one in feeling wronged by the other's prejudice (as might be the case with race), or whether the surrounding community would be likely to share the other person's prejudice (as might be more likely with disability). Sex operates differently, however; there, the extent to which we assume categorical fixity of desires based on sex may help ameliorate individual feelings of rejection. That is, we understand rejection based on sex to be rejection more because of the other person's sexual orientation than because of our sex. Cf. supra pp. I35 I-52. This presumably works differently in long-term relationships, however, than in first meetings.

214 This is one reason why individual self-inquiry, with the contextual particularities permitted by it, may nonetheless be useful. See infra section II.C, pp. I357-66. 
known as antidifferentiation. In the realm of sexual intimacy, this seems a particularly odd way to understand the ideal treatment of others. ${ }^{215}$ Think how offended a lover can be if a partner fails to notice trivial aspects of appearance, such as new glasses or a haircut; imagine if it were the partner's sex that went unnoticed. ${ }^{216}$

Rather than involve the "blindness" metaphor common in antidiscrimination law, then, perhaps intimate nondiscrimination would be desiring aspects of how someone wears his group identity - how the person inhabits his race, or his disability, for instance. That is, rather than not see those traits, one might see them and appreciate their relation to the whole of the person. Theorists of bisexuality comment on something similar with sex, because bisexuality is not what many think; it is not generally about not noticing or caring if someone is a man or a woman. Rather, bisexuality often involves desires related to maleness or femaleness, masculinity and femininity, as they relate to how they are inhabited and by whom, but not in a way that is limited to only men or only women. ${ }^{217}$

And what does nondiscrimination in the intimate domain look like, if we are operating under an antisubordination, rather than an antidifferentiation, model? For some minority group members, marrying within one's own group may be an appealing antisubordination move, as discussed above. Thus, in some contexts, choosing a mate with race or disability (or even sex) in mind may be a form of discrimination in contact that works to combat discrimination more broadly and in other domains. I return to the question of what intimate nondiscrimination might mean at the individual level later in this Part. ${ }^{218}$

\footnotetext{
215 Cf. Richard A. Wasserstrom, On Sexism and Racism, in TODAY'S MORAL Problems 75 , 96-97 (Richard A. Wasserstrom ed., 2d ed. 1979).

216 For a portrayal of the race-blindness metaphor literalized onscreen, see A PATCH OF BLUE (Filmway Pictures 1965), in which a blind white girl (played by Elizabeth Hartman) falls in love with the character played by Sidney Poitier without realizing he is black. When she learns his race from her disapproving, abusive mother (played by Shelley Winters, who won an Oscar for the role), she loves him no less, while he continues to think she loves him because she is literally "blind" to his race. In a climactic scene, she rattles off a list of things she knows about him, about his kindness and the like, ending with "and I know you're colored, and I think you're beautiful." He is moved, both to learn that she knows, and to hear her describe him as beautiful, and he responds, "Most people would say the opposite." While here love across race is made possible by disability, by literal blindness (and across disability by race, by his stylized isolation from society), the film nonetheless makes it important that she loves him with this knowledge, and incorporates it into her love for him, rather than merely seeming to tolerate it and remain blind to it.

217 See, e.g., Martin S. Weinberg ET Al., Dual AtTraction 7 (i 994).

218 See infra section II.C, pp. 1357-66 (discussing a proposal for an individual ethical self inquiry).
} 


\section{B. Abandoning the Individual Bad Actor}

What I take from the above analysis of normative meanings and descriptive possibilities is that our intimate choices - about whom to date, sleep with, or marry - do matter, but they should not be judged at an individual level. Finding a bad actor in the intimate realm may sometimes seem easy: it's the person who jilted you. But on a principled level this may be harder to do, at least on the basis of "discrimination" along recognizable axes.

As discussed, people may have strongly held preferences in the realm of desire. Those preferences may sometimes overlap with, or be shaped by, invidious sentiments toward certain groups. ${ }^{219}$ Alternatively, these preferences may be innocuous or even positive; ${ }^{220}$ regardless, they may sometimes be necessary to an individual's desire. ${ }^{221}$ They may be relatively fixed with regard to an individual, or they may change or adjust over time, just as we generally hope aspects of our desires adjust as we and our partners and peers grow older and endure sickness as well as health. ${ }^{222}$ Expressing desires that involve differentiating on the basis of race or disability (or even sex) may sometimes be hurtful to those who are not desired on a given occasion. ${ }^{223}$ But in some contexts, not acknowledging the exclusionary nature of one's desires may lead to more hurtful consequences. ${ }^{224}$

The complexities of individual desire along these axes - and thus of intimate discrimination in the sense of intimate differentiation suggest that judging others is largely misguided in this realm. Love, marriage, desire, and sex are deeply personal and highly significant aspects of human experience. To impinge on people's individual preferences in the intimate domain would seem a gross imposition on personal autonomy, in the absence of a substantial showing of countervailing harm. ${ }^{225}$ Even to judge these desires as a matter of social rather than legal regulation, as some scholars have urged, ${ }^{226}$ would risk false conclusions and perverse consequences. ${ }^{227}$ For society, much less law, to cast judgment on an individual's choices or patterns in this realm generates troubling echoes of the forms of physiological and psychiatric "conversion therapy" historically imposed upon, and some-

\footnotetext{
219 See supra section II.A.I, pp. I34I-42.

220 See supra sections II.A.2-3, pp. I342-43; II.A.7-9, pp. I346-50.

221 See supra section II.A.2, p. I342.

222 See supra section II.A.Io, pp. I350-52.

223 See supra section II.A.I I, pp. I352-54.

224 See id.

225 An example with substantial potential harms would be pedophilia.

226 See AYRES \& BROWN, supra note I2, at 30-37.

227 We might of course ask whether these problems of the individual bad-actor model could apply as well to the employment domain; this is a broader question that I do not answer in this Article, though I return to it briefly in the Conclusion.
} 
times submitted to by, homosexuals. ${ }^{228}$ Even if the sex-based desires that have been targeted by conversion therapy are more deeply entrenched, for any given individual, than desires related to race or disability - which seems plausible though not definite — we might worry about perverse consequences of imposing social judgment on these desires.

Some people's desires may be fixed along relevant axes, temporarily or permanently, such that proscribing them might mean those individuals find no sex or mate at all. ${ }^{229}$ Part III includes a discussion of why intimate discrimination matters, citing, among other things, research on health and lifespan effects of sex and relationships. ${ }^{230}$ To pass judgment on the ways people attain these benefits, when they are fortunate enough to find consensual forms of fulfilling love or sex, seems to sacrifice too much of what makes for satisfaction and meaning in human lives. Moreover, we might worry not just about the love lost generally - which might or might not be substituted with different love gained - but also about a disparate impact on love lost. Some people would surely be more likely than others to take that social judgment to heart and deny themselves what they most desire. As sex-positive feminism has highlighted, for instance, the last thing women in particular need is another reason to suppress, critique, or feel bad about what turns them on. ${ }^{231}$ The complexities of intimate differentiation - including its benefits for some members of subordinated groups and, more widely, for its role in the pursuit of love, lust, and happiness for individual seekers of many stripes - argue against a conclusion that the associated harms could justify individual-level regulation.

\section{Functionalism As an Individual Ethical Inquiry}

Does this mean that intimate discrimination should not be a matter of legal or ethical concern? The answer is no, for two reasons. First, there is another meaning of the term discrimination, which refers to structural subordination rather than to individual differentiation along protected class lines. ${ }^{232}$ Law has played a role in intimate discrimina-

\footnotetext{
228 See, e.g., Yoshino, supra note $\mathrm{I} 3 \mathrm{I}$, at $783-803$ (recounting this history as part of the assimilation demands placed on gays).

229 See supra section II.A.IO, pp. I350-52.

230 See infra section III.B, pp. I374-79.

231 See, for example, Gayle Rubin, Thinking Sex: Notes for a Radical Theory of the Politics of Sexuality, in Pleasure AND DANGER 267 (Carole Vance ed., I984); Carol Queen, Sex Radical Politics, Sex-Positive Feminist Thought, and Whore Stigma, in IDENTITy Politics IN THE Women's Movement 92 (Barbara Ryan ed., 200I); and Katherine M. Franke, Theorizing Yes: An Essay on Feminism, Law, and Desire, ror COLUM. L. REV. I8 I (200I).

232 See, e.g., Martha Minow, Making All the Difference (I990); Samuel R. Bagenstos, "Rational Discrimination," Accommodation, and the Politics of (Disability) Civil Rights, 89
} 
tion from this structural perspective and continues to do so, for instance, by prohibiting policies that create a disparate impact (in some circumstances) even when they do not involve disparate treatment. In the intimate realm, there is significant room for legal reform at this structural level, as I discuss in Parts III and IV.

Second, there is even room for some scrutiny at the individual level, warranted by the effects individual decisionmaking has on the patterns of exclusion that characterize the dating market. ${ }^{233}$ As this section discusses, there is a set of ethical questions one can and should ask oneself,, ${ }^{234}$ suggested by the functionalism framework established by employment discrimination law. ${ }^{235}$ This discussion introduces an innovative relation between law and critical analysis by first using a doctrinal framework as a tool for individual ethical inquiry, and second, using the nonlegal application of this framework to teach us something about the legal framework itself. ${ }^{236}$ This move bears a similarity to the work of legal pluralists, who demonstrate how legal frameworks come to inform extralegal contexts. ${ }^{237}$ But rather than describing a feature of how law influences culture, the analysis here uses

VA. L. REV. 825 (2003); Ruth Colker, Anti-Subordination Above All: A Disability Perspective, 82 Notre DAME L. ReV. I4I5 (2007); Tristan K. Green, A Structural Approach As Antidiscrimination Mandate: Locating Employer Wrong, 6o VAND. L. REV. 849 (2007); John A. Powell, Structural Racism: Building Upon the Insights of John Calmore, 86 N.C. L. REV. 79I (2008); Michael Ashley Stein, Same Struggle, Different Difference: ADA Accommodations As Antidiscrimination, I53 U. PA. L. REV. 579 (2004); Michael Ashley Stein \& Michael E. Waterstone, Disability, Disparate Impact, and Class Actions, 56 DukE L.J. 86I (2006); David A. Strauss, The Myth of Colorblindness, I986 SuP. CT. REV. 99; Susan Sturm, Second Generation Employment Discrimination: A Structural Approach, Ior Colum. L. REV. 458 (200I) [hereinafter Sturm, Second Generation]; Susan Sturm, The Architecture of Inclusion: Advancing Workplace Equity in Higher Education, 29 HARV. J.L. \& GENDER 247 (2006) [hereinafter Sturm, Architecture of Inclusion]; see also Samuel R. Bagenstos, The Structural Turn and the Limits of Antidiscrimination Law, 94 CAL. L. REV. I (2006).

233 For discussion of why intimate discrimination matters, due to subordination within the dating market and the repercussions beyond it, see infra section III.B, pp. I374-79.

234 Ayres and Brown provide several thoughtful examples of discrimination-related selfinquiries, see AYRES \& BROWN, supra note I2, at 37, I58, with which I agree in form, though in content I take a different position on the role of moral judgment, for the reasons discussed in section II.B, pp. I356-57.

235 Cf. AnNA Kirkland, FAt Rights 7 (2008) (using the phrase "functional individualism" to describe this aspect of employment discrimination law); $c f$. also Robert Post, Prejudicial Appearances: The Logic of American Antidiscrimination Law, 88 CAL. L. REV. I, I3-24 (2000) (referring to "functional rationality").

236 The discussion in this section particularly benefited from conversations with Adrienne Asch.

237 See, e.g., DAVID M. ENGEL \& FrANK W. Munger, Rights OF INCLUSION (2003). 
law as a heuristic ${ }^{238}$ to guide normative inquiry beyond the legal domain. ${ }^{239}$

Employment discrimination law characterizes job applicants and job holders in functionalist terms - that is, in terms of their "ability to perform" the job in question. ${ }^{240}$ Under the ADA, which offers a useful formulation of this functionalism approach, the question for the employer is whether this employee can perform the "essential functions" of the particular job (with or without reasonable accommodation). ${ }^{241}$ This inquiry forces the employer to consider the employee's abilities and the necessary components of the job to see if they are a good fit. The accommodation inquiry also forces a reconsideration of how the job is typically done.

In the context of intimate relations, the equivalent inquiry would be to ask, What are the essential functions of being $X$ 's partner? Can $Y$ perform those functions? Unlike the functionalism framework in the employment context, which privileges functionality over appearance, functionalism in the intimate context would surely fold appearance into the functionalism inquiry. That is, the essential functions of being $X$ 's partner might include being a type of person that $X$ desires, which includes being, say, a man, or being a man $X$ finds attractive. Thus,

238 Heuristic is here used in its traditional, broad meaning - that is, of an interpretive device, a device "[s]erving to find out or discover," as THE COMPACT OXFORD ENGLISH DICTIONARY I93 (2d ed. 2004) defines it - not its meaning in behavioral economics, which considers heuristics to be mental shortcuts that misfire in important ways. In the language of behavioral economics, my use of the legal framework for qualified individuals under the ADA is more akin to a debiasing strategy. A debiasing strategy aims to counteract an individual's bounded rationality, see Christine Jolls \& Cass R. Sunstein, Debiasing Through Law, 35 J. Legal STUD. I99, 20I-02 (2006), or, more broadly, as Jolls and Sunstein put it in a recent article discussing debiasing strategies of antidiscrimination law, it is a strategy "designed to counteract biases of various sorts," see Christine Jolls \& Cass R. Sunstein, The Law of Implicit Bias, 94 CAL. L. REv. 969, 973 (2006). Here we might understand the norms of intimate discrimination to lead people to make judgment errors about what range of individuals could potentially be a good partner for them (for whatever form of intimacy). The individual self-inquiry forces them to consider more precisely what they want and to question the assumed context of their relationship, in ways that may open their eyes to a broader or different set of individuals. Although individuals surely have some interest in keeping an open mind even without the pressure of an ethical inquiry, the breakdown of steps herein may help to counteract the pressure that norms can apply and thus to constrain an individual's thinking, or his or her "gut impulses," in this domain. A similar intent to counter bias through systematic consideration of needs, fit, and context presumably underpins the qualified individual and accommodation inquiry in the employment discrimination law context itself.

239 In this way, it is akin to the approach of institutional proceduralism, which uses the structure of due process analysis to devise institutional processes. See, e.g., Susan Sturm, Law's Role in Addressing Complex Discrimination, in HANDBOOK OF EMPLOYMENT DISCRIMINATION RESEARCH 35 (Laura Beth Nielsen \& Robert L. Nielsen eds., 2005). In substance, however, the probing inquiry proposed here probably bears more similarity to the idea of "institutional mindfulness," see Sturm, Architecture of Inclusion, supra note 232, at 257-58, than to either institutional proceduralism, see Sturm, supra, or debiasing, see supra note 238.

240 KIRKLAND, supra note 235 , at 7 .

241 See 42 U.S.C. § I 2 I I I (8) (2000). 
contrary to a functionalism analysis that embraces a blindness metaphor - the paradigmatic musician behind the screen - a functionalism inquiry in the intimacy context would embrace appearance as potentially functional for many people. ${ }^{242}$

I think we can fairly say that $X$ is the proper arbiter of the essential functions of being his or her partner, and of whether $Y$ can perform those functions. That is, others - friends, parents, therapist, religious community - may have views on the matter, some of which $X$ may weigh heavily. ${ }^{243}$ But ultimately, though other societies may disagree ${ }^{244}$ contemporary U.S. society has largely reached the conclusion that $X$ gets to make that decision, and I do not question that conclusion here.

Nonetheless, it could help pave the way for a world of dating with fewer categorical exclusions and hierarchies ${ }^{245}$ (and possibly more successful pairings generally) if everyone went through the steps of asking, "What are the essential functions of the job of being my partner? And who qualifies or doesn't, if I think specifically and personally, rather than merely through the norms of the dating market?" Mistakes or mistaken assumptions about one's own desire may be corrected by new experiences. ${ }^{246}$ New questions may serve a similar function. The Maxim joke presents disability as the punchline to a dating scenario, the end of an inquiry, rather than the beginning. It is assumed that the amputee in the joke would have had no sexual experience and was not going to get any now. But what if the women approaching him asked themselves, individually, what they were really looking for in a partner, what was essential to them?

For some, desire might depend on legs; for others, it might not. As noted earlier, fit is likely to be important: for a composer, hearing in a partner might be vital; for a painter who snores, a partner's hearing might be irrelevant or even problematic. ${ }^{247}$ Similarly, to ask oneself if

242 On the musician behind the screen, see, for example, Jerry Kang \& Mahzarin R. Banaji, Fair Measures: A Behavioral Realist Revision of "Affirmative Action," 94 CAL. L. REv. Io63, 1092-93 (2006).

243 See supra section II.A.6, p. I346.

244 The United States has been thought unusual in its deference to individual choice in matters of love. See, e.g., William J. Goode, The Theoretical Importance of Love, 24 AM. Soc. REV. 38, 39 (1959) (discussing the fact that "love as a common prelude to and basis of marriage is rare, perhaps to be found as a pattern only in the United States"). Recent work suggests, however, that attitudes in other countries - even countries with strong traditions of arranged marriages such as India - are growing more favorable to love matches, with families providing consultation rather than decisionmaking power. See Elaine Hatfield \& Richard L. RAPSOn, Love AND SeX: Cross-Cultural Perspectives 49-5 I (1996) (reporting on studies of attitudes and practices in various countries).

245 For more discussion of the significance of these effects, see infra section III.B, pp. I374-79.

246 See supra section II.A.IO, pp. I350-52.

247 See supra section II.A.9, pp. I348-50. 
a racial stereotype is necessary to one's desire might lead to surprising conclusions. ${ }^{248}$ If race seems important, one might ask, what aspect of it matters? Is it about shared, or different, cultural background, in which case is race an imperfect proxy? Or is it about a value assigned to the race of one's children, or about family approval? Or does one experience race as important to one's sexual desire, in a way that might suggest early imprinting, through friends or family or early erotic exposure? The aim is to ask the questions, not to assume or judge the answers. ${ }^{249}$

There are surely limits to what may come of this type of inquiry, in individual cases and more broadly. For instance, for most people, merely questioning the sex of whom they desire is unlikely to lead them to new conclusions. ${ }^{250}$ Some people of all ages do discover their sexual orientation at surprising junctures of life. ${ }^{251}$ Currently, however, in the United States, few people can avoid having ever encountered the question of whether another's sex matters to their desire. To suggest that merely asking the questions I propose here could affect sexual orientation in that sense seems highly dubious. ${ }^{252}$ The ethical inquiry I am imagining therefore does not urge self-interrogation with regard to the sex of the person one desires. ${ }^{253}$

248 Cf. supra sections II.A.5, pp. I344-45, II.A.Io, pp. I350-52.

249 Different individuals might reach different conclusions about whether to judge their own desires. Some would surely be troubled to realize that racial animus formed the basis of their preferences in the erotic domain. Whether to judge those desires, however, is a more difficult question for many reasons; for instance, it entails questions about various tradeoffs, see, e.g., supra p. 1357 , and questions about what it means to judge feelings as opposed to behavior, particularly in a domain in which behavior antithetical to one's feelings might seem itself worthy of judgment for the harms it could cause. For these reasons, I do not urge judgment as part of this inquiry.

250 A compelling exception to this may concern desires for intersexed and transgender individuals, which arguably warrant a similar self-inquiry to that proposed here for race and disability because many individuals will not have engaged in this kind of inquiry along these axes. For discussion and insight on these subjects, as well as discussion questioning the importance of gender classifications in various legal settings, see, for example, sources cited supra note I92.

251 See, e.g., Katy Butler, Many Couples Must Negotiate Terms of 'Brokeback' Marriages, N.Y. Times, Mar. 7, 2006, at $\mathrm{F}_{5}$; see also supra section II.A.Io, pp. I350-52.

252 On the assumption that our sex-based desires are relatively fixed, at least at the individual level, see supra section II.A.IO, pp. I $350^{\circ}-52$.

253 Ayres and Brown make a strong case, however, for raising one's children in a way that does not presuppose hetero- or homosexuality. AYREs \& BROWN, supra note I2, at 23-30. This approach, as it affirmatively embraces whatever sexual orientation children arrive with or develop, seems a sound one for nurturing parenting. Ayres and Brown go further, however, and argue for trying to raise one's children to be bisexuals, on the ground that bisexuality is a more moral way of being than monosexuality, because it does not involve discrimination (in the sense of differentiation). Id. at 30-37. They are, for the same reason, "concerned that so many progressives are unselfconscious in even asking the question whether their own sex discrimination is moral." Id. at 37. For the reasons discussed earlier, I am more troubled than they by the idea of imposing moral judgments on other people's sexual desires, see supra section II.B, pp. I356-57, and I am agnostic about the question of whether to judge one's own desires, see supra note 249. 
For some people, it may also not be new to consider probing questions about the relationship between race and their own desires; for others, it may be. ${ }^{254}$ Such questions are probably new for more people with regard to disability, since they are so rarely asked. ${ }^{255}$ In both cases, the argument here is that it is worth individuals' asking themselves what the essential functions are of being their partner (for dating, marriage, sex, or whatever intimate practices they are seeking), and then to ask whether a particular race or disability precludes someone from fulfilling those functions.

To ask oneself the question about essential functions is to invite a focused consideration of one's own needs and desires. ${ }^{256}$ It also forces one to pause over the fact that a person's race or disability is only one of the person's many traits. ${ }^{257}$ This inquiry may therefore serve a kind of debiasing function by helping to contextualize these traits and to encourage more than a gut response based on the norms of intimate discrimination. ${ }^{258}$

The inquiry, following the ADA's functionalism approach, should also involve an additional step. After articulating the essential functions, the questioner should ask whether any accommodation - either in the sense of a particular adjustment of one's individual assumptions, immediate environment, or practices, or in the sense of a shift in the baseline of the surrounding community - would enable a relationship that otherwise might look too difficult. To make this suggestion is to highlight the fact that accommodation embraces two different, but related, ideas. Accommodation is generally thought of as individually tailored adjustments that make one person's impairment less disabling by allowing that person to adjust to the world as it is (this is what I

\footnotetext{
254 See, e.g., Chito Childs, supra note $\mathrm{I} 69$, at 2774 (reporting that in her research on attitudes toward interracial relationships, "most whites interviewed replied that they 'had never really thought about it' and 'didn't know it was an issue' when asked about interracial relationships"). Moreover, for those who have encountered the question before, to ask about the possibility of dynamic accommodations, see infra p. $\mathrm{I}_{3} 6_{3}$, might affect their understanding of their desires, or at least of the issues.

255 Cf. supra p. 1352 (discussing the lack of mainstream terms for people who date inside or outside of their (dis)ability).

256 The inquiry would include an examination of one's past experiences and relationships that may have shaped one's assumptions about categories of potential partners. Recognizing the shaping role of one's past may lead to discoveries about the limited experiences that make up one's perceived desires, whether alterable or not. Relatedly, to examine whether another's race or (dis)ability is a necessary qualification, one presumably needs to consider multiple and diverse members of the relevant groups.

257 Cf. Asch, supra note 1o, at 235-36, 247-55 (making related arguments in the context of prenatal testing); Adrienne Asch \& David Wasserman, Where Is the Sin in Synecdoche?: Prenatal Testing and the Parent-Child Relationship, in Quality of Life And Human Difference I72 (David Wasserman et al. eds., 2005) (discussing the ethics of prenatal testing decisions by analogy to horizontal intimate relationship decisions).

258 See supra note 238 (explaining debiasing).
} 
have elsewhere called the "static model of accommodation").259 But accommodation also encompasses another meaning, which I have called the "dynamic model of accommodation," which refers to a questioning of the baseline structure (of a workplace or, it could be, society more generally) that makes an impairment disabling. ${ }^{260}$ Under the dynamic model, one asks whether the individual disability and need for accommodation can show us any problems with or ways to improve on our baseline assumptions that create disability. ${ }^{261}$

In the self-inquiry about intimate discrimination, both models of accommodation are potentially meaningful. Within the static model, one might ask if there is any individualized adjustment that would make a characteristic associated with disability or race no longer inhibiting of someone's prospects for performing the essential functions of being one's partner. ${ }^{262}$ For instance, adjustments to one's home, social activities, or need for parental or community approval - or a move to a different building or neighborhood - might mean a particular disability is less disabling, or another's race less challenging. ${ }^{263}$ Whether these adjustments seem too burdensome would depend on the individual engaging in the inquiry. Within the dynamic model, one might ask whether the relevant identity category would still matter to one's intimate desires if the world were different than it is - in its laws, norms, material conditions, or architecture, for instance - and whether that alternative imagined world would be a better one. The dynamic model inquiry is more likely to be theoretical rather than practical, since changing the baseline of the surrounding community may be impossible, but the inquiry might nonetheless be instructive, at least for one's views of the world if not of a relationship. ${ }^{264}$ Such

259 See Elizabeth F. Emens, Integrating Accommodation, I56 U. PA. L. REV. 839, 894 (2008).

260 Id.

261 See id. at 894-96.

262 True to the accommodation doctrine, one might also ask whether the accommodation is "reasonable" and not an "undue hardship" in the sense of the costs not being disproportionate to the benefits, a concept that is interesting to ponder in this context. See, e.g., Vande Zande v. Wis. Dep't of Admin., 44 F.3d 538, 546 (7th Cir. I995).

263 See infra section III.A.2, pp. I369-73 (discussing a hypothetical comparing relatively accessible and inaccessible cities for their effect on dating and disability); infra section IV.E.2, pp. I398-99 (discussing the burdens that residential segregation places on interracial relationships).

264 By including the accommodation step, I am proposing an inquiry that goes beyond what Kirkland considers narrowly to be "functional individualism," but this hybrid is still a functional account of personhood compared to the embedded personhood idea with which Kirkland contrasts it. See KIRKLAND, supra note 235, at 9-I I. As Kirkland puts it, "[People with disabilities accommodated under the $\mathrm{ADA}]$ are still functional individuals — qualifications still matter for jobs — but the logic of functioning has been partially uprooted by a logic of blame-shifting." Id. at I27. The blame-shifting function of the accommodation inquiry, particularly in its dynamic form, should therefore encourage an interrogation of existing hierarchies that inform desire and related decisions. Post does not consider the accommodation inquiry in his analysis of "functional rationality." See Post, supra note 235 , at I4. 
changes in perspective could affect how one responds to friends and family (or even strangers) who make counternormative choices and what messages one conveys to the next generation.

In some cases, this form of self-inquiry might be eye-opening and might allow for the possibility of an intimate connection otherwise dismissed categorically; in other cases, the obstacles would seem too great, or alternative arrangements might be irrelevant to the shape of an individual's desire or goals. But whether for shifts in behavior or only in perspective, it would be useful for individuals to engage in a functionalism inquiry modeled on that demanded by employment discrimination doctrine under the ADA. Moreover, though framed as a self-inquiry, this inquiry may work best for some individuals through, or in conjunction with, dialogue with thoughtful friends or trusted others. My emphasis on self-inquiry aims only to highlight that the ultimate arbiter of this inquiry, as I imagine it, is the individual. ${ }^{265}$

The functionalism model of personhood has been criticized in the employment domain for naively imagining that individuals can be reduced to their mere functionality. These critiques have, rightly I think, pointed to the ways our selves are defined by more than our abilities; these critiques emphasize that our selves depend crucially on our "embedded personhood." 266 Anna Kirkland explains the limits of the functionalism approach thus: "What I call embedded personhood tells us that some aspects of a person cannot simply be ignored because they supply valuable information about what kind of person she is and how we can understand and judge her within a particular context."267 She continues, "What we see in the mirror every day is a race, a gender, an able body or a disabled body, fatness or thinness, age or youth. These traits anchor us within communities and render us recognizably ourselves to others." 268

Kirkland is right that these traits are more than incidental to our identities, to the ways that we mean in the world. She aptly says

\footnotetext{
265 One could potentially conduct a similar inquiry about one's friendships, asking about the race and disability makeup of one's friends, about the essential functions of being one's friend and whether race or disability is relevant, and about whether any changes to immediate circumstances or the broader community would change this assessment. Such an inquiry might pertain to ongoing decisionmaking for more people than would the intimate inquiry, because many people continue to form new friendships even if they have committed (as many do) to one monogamous sexual relationship. Moreover, the friendship inquiry highlights the potential utility of looking to impact or results, in addition to intent, in this self-examination. For varying perspectives on the meaning, uses, and proper legal treatment of friendship, see Ethan J. Leib, Friendship and the Law, 54 UCLA L. REV. 63 I (2007); Laura A. Rosenbury, Friends with Benefits?, I06 MICH. L. REV. I89 (2007). See also Katherine M. Franke, Longing for Loving, 76 FORDHAM L. REV. 2685, $2702-05$ (2008).

266 KIRKLAND, supra note 235, at 9-I I; see also Post, supra note 235, at I4.

267 KIRKLAND, supra note 235 , at 9.

$268 I d$. at I I.
} 
therefore that these features of a person cannot "simply" be ignored. ${ }^{269}$ Nonetheless, I think that functionalism can be useful as a kind of heuristic, as an interpretive device for understanding ourselves and the world we inhabit. Though these traits cannot be entirely ignored, they may be usefully (even if only partially) set aside to consider the importance of other traits and, ultimately, to evaluate properly the significance of the protected traits themselves. The fact that we cannot perform this functionalism inquiry perfectly does not mean we cannot or should not perform it at all. Moreover, the functionalism heuristic as presented by the ADA - does more than ask us to consider "intrinsic worth" as against superficial traits; ${ }^{270}$ it asks us to interrogate our own assumed desires, and then to question the influence of the surrounding context on our perceptions of our selves and those we might desire.

Indeed, considering functionalism as a way that one individual contemplates what she specifically wants and needs in an intimate partner - recognizing that love and relationships, and even sex, will often depend upon the whole of the partner, not just the sum of the parts helps us to see why the inadequacy of functionalism to capture the depths of persons does not render it useless as an inquiry for unsettling discriminatory impulses in the employment domain. To engage in this inquiry may press us to look past categorical types and expectations, and in fact to see the person more clearly, which may ultimately include appreciating how she is embedded in the very identity traits that the exercise invites us temporarily to set aside. In this way, though imperfect, the functionalism inquiry in the employment domain can provide us with a practical tool for reimagining the workplace while also giving us insight into the relationship between the individual and the identity category at issue.

Whether or not the ethical self-inquiry discussed here opens up individual intimate possibilities, the inquiry into essential functions, and possible static and dynamic accommodations, should encourage an interrogation of existing norms and social structures. This discussion of the individual self-inquiry thus accomplishes two ends. On the one hand, we see a legal framework usefully informing an exercise in individual ethics. And on the other, we see that applying this legal frame-

\footnotetext{
269 Indeed, some may hope that these traits are part of what another loves about them. See supra section II.A.I2, pp. I $354-55$ and note 2 I6.

270 Post notes this possible use of the functionalism inquiry, suggesting that the aim of it is to consider "intrinsic worth," which makes it difficult to distinguish individuals. See Post, supra note 235 , at I $2-\mathrm{I} 3$. I think instead that this inquiry, particularly as required under the ADA with its accommodation requirement, can inspire a careful attention to context and the ways it can be disabling.
} 
work to the intimate domain gives us insight into the utility of the legal framework itself.

\section{ON STRUCTURAL DISCRIMINATION}

"Like traffic accidents, love accidents often happen close to home."

- Amy Spencer, Are You Ready To Find the One? ${ }^{271}$

People may have strong preferences about the types of people they like and desire. Though those preferences may sometimes overlap with, or be shaped by, invidious sentiments towards certain groups, such preferences may also be innocuous or even positive. In any case, an individual's preferences may be fixed to some extent. For these and other reasons discussed in Part II, trying to punish or restrict individual intimate choices in the name of antidiscrimination thus seems misguided and beyond the realm of appropriate state intervention, even though structured self-inquiry may be an ethical endeavor.

Yet the state does play a role in intimate discrimination, though we like to think otherwise. The state shapes both the accidents (whom we meet) and the calculations (who we think is an appealing match) of intimate decisionmaking. This Part explains this claim. It concludes by discussing the reasons that intimate discrimination matters at a structural level, as a prelude to Part IV's discussion of the steps the state should take in this domain.

\section{A. The State's Role: Of Accidents and Calculations}

What determines sexual and other intimate behavior? Many factors likely come into play, including biology, ${ }^{272}$ personality traits and fit, ${ }^{273}$ desires for and against one's own family members, ${ }^{274}$ a rational (or quasi-rational) calculus of what will make for a good life or a good night, ${ }^{275}$ intention and effort, ${ }^{276}$ and social pressures of direct and indirect sorts, ${ }^{277}$ to name a few. These factors likely matter more or less

271 Amy Spencer, Are You Ready To Find the One?, CHEMISTRy, http://www.chemistry.com/ datingadvice/ReadyToFindTheOne (last visited Feb. 8, 2009).

272 See, e.g., David M. Buss, The Evolution OF Desire (rev. ed. 2003); David M. Buss, The Evolution of Love, in THE NEw PSychology OF LOve 65 (Robert J. Sternberg \& Karin Weis eds., 2006); $c f$. infra note 280.

273 See, e.g., Dick P.H. Barelds \& Pieternel Barelds-Dijkstra, Love at First Sight or Friends First?: Ties Among Partner Personality Trait Similarity, Relationship Onset, Relationship Quality, and Love, 24 J. SOC. \& PERS. RELATIONSHIPS 479 (2007).

274 See, e.g., Sigmund Freud, The Interpretation of Dreams 294-98 (James Strachey trans. \& ed., Avon I998) (1900).

275 For an important rationalist account of love in a philosophical vein, see MARTHA C. Nussbaum, Upheavals of Thought: The Intelligence of Emotions 24-33 (paperback ed. 2005). See also infra section III.A.2, pp. I369-73.

276 See, e.g., ERICH Fromm, The ART OF Loving (Continuum 2000) (I956).

277 See, e.g., Goode, supra note 244, at 39-40. 
depending upon the individual and the context. Contemporary work in the psychology of intimate relationships tends to adopt an interactionist approach, assuming that various biological and cultural factors combine to lead to the phenomena we call love and desire. ${ }^{278}$ This section considers the state's role in lovemaking, whether what brings us together is understood as a matter more of accidents or of calculations.

I. Accidents of Sex and Love. - One factor that certainly matters to who loves whom, in a but-for sense, is the simple fact of who does and does not meet - or what demographers sometimes call "propinquity." 279 This is undeniably true in the sense that one will not befriend, bed, or marry someone whom one never meets. ${ }^{280}$ If a man in Ovid, Colorado, never meets anyone from Peru (in person or electronically), then the Ovidian will never marry a Peruvian. If the Ovidian never meets someone from another racial group, the Ovidian will never marry outside his racial group. Geography (real and virtual) shapes a result in the intimate domain on an individual level.

Expanding out from scenarios of extreme isolation, we might reasonably conclude that how often people encounter others of certain groups affects the odds of pairings across those groups. Imagine a school system segregated strictly along disability/ability lines. In this scenario (which is illegal under the ADA for its simple segregationist model), all disabled teens go to one high school, and all nondisabled teens go to a different school. In the disabled school, the teens are grouped according to their disabilities, and all teaching and recrea-

278 See, e.g., Garth Fletcher, The New Science of Intimate Relationships (2002); Michael R. KaUth, True Nature: A Theory of Sexual Attraction (2000).

279 See, e.g., Diane C. Fujino, The Rates, Patterns and Reasons for Forming Heterosexual Interracial Dating Relationships Among Asian Americans, I4 J. SoC. \& Pers. Relationships 809, 8I 2-I3 (I997); Yancey, supra note 44, at I8I; see also Shana Levin, Colette van Laar \& Jim Sidanius, The Effects of Ingroup and Outgroup Friendships on Ethnic Attitudes in College: A Longitudinal Study, 6 GROUP PROCESSES \& INTERGROUP REL. 76 (2003). Propinquity is of course only one element in dating and sexual choices, and the size of its effect is unclear. Recent experimental work on dating websites, which attends to preferences based on race (but not sex or disability), urges that "sorting is not entirely due to search frictions, but rather that sorting patterns arise as a consequence of mate preferences, rational behavior, and an equilibrium mechanism by which matches are formed [- which] is not to say that search frictions are entirely absent in marriage markets." Günter J. Hitsch, Ali Hortaçsu \& Dan Ariely, Matching and Sorting in Online Dating 5 (Mar. 2008) (unpublished manuscript), available at $\mathrm{http} / / / \mathrm{ssrn} . c 0 \mathrm{~m} / \mathrm{abstract}=\mathrm{I}$ I I 3243.

280 The time and context of meeting may also matter in interesting ways. See, e.g., Gary W. Lewandowski Jr. \& Arthur P. Aron, Distinguishing Arousal from Novelty and Challenge in Initial Romantic Attraction Between Strangers, 32 SoC. BeHAV. \& Personality 36I, 36I-65 (2004) (reporting, inter alia, on a series of studies showing that strangers meeting in high arousal settings — as on a shaky bridge - were more likely to report attraction than those in low arousal settings); see also Martie G. Haselton et al., Ovulatory Shifts in Human Female Ornamentation: Near Ovulation, Women Dress to Impress, 5 I HORMONES \& BEHAV. 40, 42 (2007) (reporting that, around the time of ovulation, women engage in more "active ornamentation" in their clothing and other apparel in ways that lead male and female judges to rate them as more attractive). 
tion occur within a particular disability. So deaf students form one subunit of the school, blind students another, quadriplegic students another, and schizophrenic students another. (Students with more than one disability are placed randomly into a subunit of one of their disabilities.)

This institutional structure would probably increase the likelihood that a disabled student would form relationships with others who share her particular disability, rather than with someone with a different disability. Regardless of any prior preferences, the student spends all her time at school with those who share her disability. It also seems reasonable to conclude that the disabled students are more likely to pair across disabilities than with nondisabled teens, given their increased chances of meeting before or after school or between classes, since they are housed in the same building, entirely separate from the nondisabled students.

Now imagine one day the schools and classrooms are joined. At first, we might expect preferences to have been shaped by the prior arrangement, but over time, more intimate connections might form across the groups previously segregated. It would be surprising if who mixes with whom mapped perfectly onto what intimate relationships formed, but the contrast between no mixing and complete mixing dramatizes the fact that the structure of a community plays a role.

Casual contact creates the conditions for the accidents of sex and love. ${ }^{281}$ Of course, whom we choose as our partners depends largely on deeply held private preferences, perhaps particularly with regard to sexual desire, and on rational calculations (the next topic), perhaps particularly when people ponder marriage. But accidents do occur. Crucial accidents may be the stuff of fiction, ${ }^{282}$ but they are also, some of the time, the stuff of life. And the state plays a role in shaping these accidents.

This is what the term "accidents" captures: the sense that who will love whom and who will desire whom may sometimes be an "unpredictable, mysterious, and elusive phenomenon" 283 at an individual

281 This was of course well understood by race segregationists. See infra notes $330-32$ and accompanying text.

282 E.g., William Shakespeare, A Midsummer Night's Dream; Back to the FuTURE (Universal Pictures i 985); While You WeRE SLEEPING (Hollywood Pictures i995).

283 Amy L. Wax, Discrimination As Accident, 74 IND. L.J. I I29, I230 (1999). Wax uses this evocative description of accident, surprisingly, to argue that there is no way to shape the occurrence of the accidents of unconscious bias in the workplace. I say surprisingly because, to me, the utility of the word accident comes from its implication that individuals may be erratic, but the surrounding environment exerts influence and thus can be usefully regulated. This is not the place for a full examination of Wax's argument, but I think her different path comes in part from her assumption that the science of unconscious bias is at such a primitive stage that such bias can never be predicted or curtailed, see, e.g., $i d$. at I I33, an assumption that others have challenged. See, for example, the essays in Symposium, Behavioral Realism, 94 CAL. L. REV. 945 (2006). By 
level, and yet be inevitably shaped by the infrastructure - what Moran has called the "structural influences"284 — that determines who meets whom. In this way, even a romantic view of love is consistent with an appreciation that the state shapes our romantic choices - as is a rationalist view, which is our next topic.

2. Calculating Desire. - Some lovers temper romance with rationality: they consider, implicitly or explicitly, the costs and benefits of being in a relationship with a particular other. ${ }^{285}$ One version of a rationalist account falls under the headings of "matching theory" or "assortative mating." 286 Empirical work in this area indicates that people tend to pair with similar partners along dimensions such as attractiveness, education, wealth, earnings, and age (as well as race, as noted earlier). ${ }^{287}$ Controversies persist as to whether people seek those who are more attractive (or richer, etc.) than themselves, but end up sorting into similar matches because everyone cannot have the most attractive (richest) mate, or whether people simply seek those who are similarly situated in terms of attractiveness (wealth). ${ }^{288}$ Either way, state policies affect the distribution of social capital — such as education, wealth, and earning power - and thus play a role in shaping the barriers (and on-ramps) to entry into intimate relationships.

In the context of race, Randall Kennedy has observed that the "poverty, unemployment, lesser educational opportunities, and like deprivations" faced by many people of color place them at a disadvantage in the U.S. market for marriage. ${ }^{289}$ Kennedy thus highlights the role our personal and social assets can play in our prospects for finding or keeping a (desirable) mate. Kennedy's work also offers vivid ac-

contrast, there is no question that whom one loves and desires is, at least to some extent, shaped by whom one encounters.

284 MORAN, supra note 23, at II9.

285 Rachel Moran is right to suggest that we like to think of "rationality [as] misplaced in matters of the heart"; however, as she acknowledges, some of our dating methods - such as the search mechanisms of many commercial dating services - make explicit the role of calculations. Id. at $\mathrm{I} 3$.

286 See Lisa K. Jepsen \& Christopher A. Jepsen, An Empirical Analysis of the Matching Patterns of Same-Sex and Opposite-Sex Couples, 39 DEMOGRAPHY 435, 435 (2002); S. Alexander Takeuchi, On the Matching Phenomenon in Courtship: A Probability Matching Theory of Mate Selection, 40 MARRIAGE \& FAM. REV. 25, 30 (2006). For another version of a rationalist account, see NUSSBAUM, supra note 275.

287 See, e.g., Jepsen \& Jepsen, supra note 286 , at $450-5$ I (finding matching along all axes studied - including race, age, schooling, investment income, earnings, and blue or white collar job though more for non-labor-market variables (the first four listed) than for labor-market variables, particularly for married different-sex couples); Takeuchi, supra note 286 , at $27-28$ (discussing the data on attractiveness).

288 See, e.g., Peter M. Buston \& Stephen T. Emlen, Cognitive Processes Underlying Human Mate Choice: The Relationship Between Self-Perception and Mate Preference in Western Society, ioo Proceedings NAT'L ACAD. SCI. 8805 (2003); Takeuchi, supra note 286, at 26-27.

289 KENNEDY, supra note Io, at 520. 
counts of the costs endured by interracial couples in a hostile world. Though most of these accounts are historical, some of those costs still exist, as I discuss further in Part IV. Perhaps less well known or remarked upon, however, are the analogous barriers to entry surrounding intimacy and disability that can affect the rational calculation of whether to enter or remain in a relationship when one or both partners has a disability. A second hypothetical captures the point.

Imagine two towns: Accessible City (A-City, for short) and Inaccessible City (I-City). Janet, an attractive young lawyer and triple amputee who uses a wheelchair, lives in A-City, where she meets John, a nondisabled librarian, and they begin dating. In A-City, where everything is accessible, John and Janet can go wherever they please together - parks, museums, restaurants, bars. They go dancing and see movies; they take public transportation to the botanical gardens and the zoo. Most private buildings are accessible, at least on the ground floor, so they visit friends together, attend parties, and enjoy an easy and relaxed social life. In addition, the state in which A-City is located has a welfare system that provides personal assistance to Janet for daily self-care tasks (as needed), and were she to marry, Janet's state assistance would continue as before.

Janet then moves to I-City, in a far away state, for a new job, prompting a breakup with John. In I-City she meets Tim, another lawyer, at a local Bar event, and they hit it off. Janet hopes their spark might develop into a relationship, but even dating proves difficult. Public transportation in I-City is only partly accessible - with most subway stops accessible only by stairs and more than half the city's buses without working lifts - and there are few accessible taxis. Difficulties with transportation make Janet late to work on numerous occasions, at first threatening her status in her new job, though she adjusts by leaving home at ridiculously early hours (something Tim, not a morning person, finds tedious). Most restaurants have steps up to their entrance or such narrow aisles between tables as to make movement in a chair impossible. (Some of these obstacles violate the public accommodations title of the ADA, ${ }^{290}$ but compliance is poor and lawsuits have been rare. ${ }^{291}$ ) The few restaurants that are accessible have tables with big circular bases on the table legs, so Janet has to park her wheelchair back from the table, making intimacy challenging. Movie theaters and stores are all hit or miss in their accessibility. Almost no one's home is accessible, so they cannot attend dinner parties

29042 U.S.C. $\$$ I 2 I 8 I-I 2 I 89 (2000).

291 Cf. Samuel R. Bagenstos, The Perversity of Limited Civil Rights Remedies: The Case of "Abusive" ADA Litigation, 54 UCLA L. REV. I (2006) (discussing the many problems with enforcement of the public accommodations title of the ADA, including court hostility and the unavailability of damages). 
together. Tim's friends feel awkward about this and debate whether even to invite him to things, knowing Janet will not be able to join him. They begin to ask him, subtly and not so subtly, whether he would want to face a lifetime of such constraints. ${ }^{292}$ One of them, a social worker, points out that I-City's state revokes personal-assistance services if a disabled beneficiary marries, on the assumption that her spouse will take on those duties. ${ }^{293}$ Janet has many more daily frustrations in I-City, and feels a great deal more anger and hostility, which creates tension and conflict with Tim, who sees her perspective but also does not experience it as she does. When he encourages her to be positive, she feels alienated from him and accuses him of an inability to understand her world. ${ }^{294}$ He feels excluded, and the distance between them grows.

Janet's prospects as a dating partner look starkly different in the two towns, based on decisions by the state about infrastructure, policy, and enforcement. Her partner faces strikingly different costs related to her disability in I-City as opposed to A-City, making the prospect of dating her look rather different under any explicit or implicit rational calculus. The situation in I-City would be only starker if Janet had actually lost her job; in this and other ways, the hypotheticals do not come close to depicting the material consequences that can arise from a lack of accessibility or of legal protection against discrimination. Other variations on the hypotheticals would illuminate further dimensions of the issues. For instance, if Janet's disability had been something she could conceal, such as a psychiatric disability, there could have been added difficulties for the relationship surrounding her disclosure to her partner and dilemmas about whether or when to tell others. ${ }^{295}$ In addition, although the emphasis in the hypotheticals has

292 Cf. Kroll \& Klein, supra note 79; Simi Linton, My Body Politic ior (2006).

293 See infra section IV.D.2, pp. I390-9I.

294 Cf. GOFFMAN, supra note I8I, at 3 I "The relation between the stigmatized and his standin can be an uneasy one. The person with a failing may feel that reversion to type may occur at any moment, and at a time when defenses are down and dependency is up."); Chito Childs, supra note $\mathrm{I} 69$, at 2780 (describing black interviewees', on the subject of interracial relationships, "offer[ing] various examples of how whites mistreat blacks in general, connecting this to the probability that a white individual would use a racial slur, disrespect the black partner, and simply not understand what it means to be 'black in America'"); Kim McLarin, Race Wasn't an Issue to Him, Which Was an Issue to Me, N.Y. TIMES, Sept. 3, 2006, at ST9 (describing the pain in a mixed-race relationship when one "person ... grapples with race" and one does not); SoMETHING NEW (Focus Features 2006) (portraying a mixed-race couple's splitting up when the white partner proposes a break from discussing race, after the black partner had been complaining about racism at work).

295 See, e.g., GofFMAN, supra note I8I, at 99. Goffman provides the following quotation as an example of "stigma management work done by wives of mental patients":

I haven't gotten too friendly with anyone at the office because I don't want people

to know where my husband is. I figure that if I got too friendly with them, then they 
been on ongoing relationships, many of the cities' differences could affect prospects for sexual encounters as well, which depend on accessing places to meet others and to interact sexually, as well as on one's attractiveness to potential mates. Social status, opportunities, and income can affect a person's attractiveness and confidence, as can the presence or absence of attractive and successful group members in the relevant community and available media. ${ }^{296}$ Such outcomes are easy to imagine as different in A-City and I-City.

In addition to showing the significance of law to intimate discrimination, the contrast depicted in this hypothetical portrays a central idea of disability law and theory: the social model of disability. Unlike the so-called medical model, which views disability as a medical problem with the individual, the social model views disability as inhering in the interaction between the impairment and the social environment. ${ }^{297}$ As the writer Simi Linton, who uses a wheelchair, portrays the difference between the medical and social models, "If I want to go to vote or use the library, and these places are inaccessible, do I need a doctor or a lawyer?"298 Consistent with the social model, Janet is much more disabled - and so is her partner, in effect - in one city than in the other, entirely because of the law and structures of the two cities, and not because of any difference in her physical impairment.

The effects of inaccessibility on partners of disabled people may help to explain the bipartisan support for the ADA's passage in I990. Scholars have noted the many members of Congress who had disabled relatives, reasoning that these intimate affiliations gave nondisabled legislators more sympathy with the challenges and stigma faced by disabled people. ${ }^{299}$ An explanation based on sympathy may be right, but incomplete. As the hypothetical about A-City and I-City suggests, these intimate connections may also have given nondisabled legislators an understanding of the social model, through their firsthand experience with the ways that inaccessibility creates disability, both for dis-

would start asking questions, and I might start talking, and I just think it's better if as few people as possible know about Joe.

Id. (quoting M.R. Yarrow, J.A. Clausen \& P.R. Robbins, The Social Meaning of Mental Illness, I I J. SoC. Issues 33, 36 (I955)). For further discussion of issues and research related to disclosure, see Emens, supra note 259, at 903-08.

$296 C$ f. infra note 326 and accompanying text (discussing the significance of films, such as Murderball, to ideas of desirability).

297 See, e.g., Samuel R. Bagenstos, Subordination, Stigma, and "Disability," 86 VA. L. Rev. 397, 428-33 (2000); see also Michael Oliver, Understanding DisABILITY 30-42 (ig96) (explaining the "social model" as distinguished from the "individual model").

298 LINTON, supra note 292, at I 20 .

299 See, e.g., Joseph P. Shapiro, No Pity: People with Disabilities Forging a New Civil Rights Movement i i8-ig (ig93); Stein, supra note 232, at 627. The presence in Congress of people who themselves had disabilities - most notably, Rep. Tony Coelho - was also vitally important to the Act's passage. SHAPIRO, supra, at II 7-I8. 
abled people and for those who accompany them. Intimate relationships across race may perform a similar function, in giving members of superordinate groups experience with the ways discrimination shapes the category of race. ${ }^{300}$

The hypotheticals in this section could also be rewritten to involve other categories. One can imagine analogous scenarios involving cities more or less disabling to interracial couples, through features such as the availability of integrated neighborhoods, and to same-sex couples, through the practical and symbolic significance of the availability of marriage. As another example, applicable to all three groups, hate crime laws could affect the experience of these relationships, and thus the rational calculation of whether the benefits of such relationships are worth the costs.

These hypotheticals about accidents and calculations portray the structural truth lurking beneath David Mura's words in the opening epigraph: "[T]here is[] a relationship between whom I desire and whom I hire, [and] between whom I want my children to desire and whom I hire." 301 Mura's words seem to suggest an individual point: I have similar feelings toward some groups that make me inclined to hire the same people I desire. ${ }^{302}$ But they also reflect the more important point of this examination of intimate discrimination: whom I hire shapes whom I meet and might desire, and whom my children meet and might desire. And vice versa. Whom I desire and date and marry, and whom my children desire and date and marry, shapes whom I know to hire. And further. Whom I hire shapes who has the social capital to be good enough to date my children. And whom my children marry shapes the people I want to hire, the people to whom I want to give opportunities for advancement and access to the good life.

300 These effects may also work across sexual orientation: think here of a bisexual seeing what it is to be gay in a particular community through his first relationship with another man, or a straight person seeing something of how it feels to be a sexual minority through a relationship with a bisexual.

301 Mura, supra note I, at 282; see also supra p. I309.

302 Sex operates differently from race and disability, as discussed in Parts I-II, pp. I3 I5-66. Cross-sex desire may not lead to hiring, but to a separate spheres mentality. But the broader points that follow in this paragraph have some bearing on sex. For instance, the sex of the people one's children date may affect hiring choices; think here of people with unexpectedly tolerant attitudes on gay issues who, it turns out, have a gay child. In addition, an individual's dating experiences with members of the opposite sex whose gender is not wholly conventional may be more willing to hire those whose gender is not wholly conventional. (The question of whether a straight-identified person's same-sex sexual experiences leads to more tolerant attitudes, or to more homophobia, is complicated. See, e.g., Yoshino, Bisexual Erasure, supra note i I I.) 


\section{B. Why Intimate Discrimination Matters}

As noted in the Introduction, these are challenging times for antidiscrimination law. The antidiscrimination project is plainly incomplete. Widespread inequalities persist, along numerous lines, including race, disability, and sexual orientation. Yet our current antidiscrimination protections do not seem to be adequate to the problem. This challenge has been given various names, including "preservation through transformation" 303 - the name Reva Siegel gives to the process by which discriminatory practices morph and persist in new forms in response to legal prohibitions - and "second generation discrimination"304 — the term Susan Sturm applies to the subtler, more diffuse patterns of interaction that lead to disparate outcomes even in the absence of any individual ill will.

In the face of such a challenge, a careful examination of intimate discrimination matters. As we have seen already, this inquiry yields useful insights about the categories of discrimination and our ways of understanding them. But its use is not merely conceptual. Intimate discrimination is itself important as a practical matter, as this section discusses. Because of intimate discrimination, some groups are excluded from opportunities for intimate affiliation, which itself has consequences for members of those groups, and everyone's intimate opportunities are limited by the current structures of discrimination. Moreover, intimate discrimination has ramifications for discrimination beyond the intimate sphere.

I. The Direct Harms of Intimate Discrimination. - Social stigma and structural constraints exclude some people from meaningful participation in the dating, sex, and marriage markets. The norm of desexualization for people with disabilities both reflects and contributes to the relatively limited opportunities many disabled people face in forming intimate relationships. ${ }^{305}$ Moreover, inadequate implementation of legal entitlements - such as inadequate accessibility in public transportation and public accommodations - inhibits disabled people from meeting others and developing relationships. ${ }^{306}$ In addition, relative poverty and low employment rates among disabled people reduce

303 Reva B. Siegel, "The Rule of Love": Wife Beating As Prerogative and Privacy, ro5 Yale L.J. 2 I I 7, 2 II 9 (I996).

304 Sturm, Second Generation, supra note 232, at 468.

305 See supra section I.C, pp. I325-30.

306 On the inadequate implementation of the ADA, see, for example, BACKLASH AGAINST THE ADA: REINTERPRETING Disability Rights (Linda Hamilton Krieger ed., 2003); Bagenstos, supra note 29I; and Feldblum, supra note I34. For an argument that the Supreme Court's interpretations of the ADA reflect contradictions within the disability rights movement itself, see SAmuel R. Bagenstos, LaW and the Contradictions of the Disability RightS MOVEMENT (forthcoming 2009). 
the social capital they bring to the intimacy markets. ${ }^{307}$ As noted earlier, Randall Kennedy has made related points about the relative impoverishment of people of color, as it affects their prospects for intimate relationships. ${ }^{308}$ Race and gender also intersect to create particular subgroups who are relatively excluded in their intimate prospects, in particular, African American women.

Limited opportunity for sex and marriage can have welfare consequences. Empirical studies suggest that both sex and marriage have positive physical and mental health effects. For instance, studies show a positive relationship between lifespan and frequency of sexual activity, orgasm, or enjoyment of sex. ${ }^{309}$ Sex has also been shown to increase happiness, ${ }^{310}$ though some research finds this to be more true for men. ${ }^{311}$ Marriage is also associated with decreased mortality risk and better health outcomes, ${ }^{312}$ though some work has also found the mortality effect of marriage to be greater for men than for women. ${ }^{313}$ In addition, marriage predicts lower levels of depression and higher levels of life satisfaction than those reported by the never-married, divorced or separated, and widowed, ${ }^{314}$ with some research finding that

307 See, e.g., Samuel R. Bagenstos, The Future of Disability Law, II4 YALE L.J. I, 9 (2004) (discussing poverty and low rates of employment among people with disabilities).

308 KENNEDY, supra note io, at 520.

309 See, e.g., Erdman B. Palmore, Predictors of the Longevity Difference: A 25-Year Follow-Up, 22 Gerontologist 5I3, 5 I5 (I982); Daniel R. Seldin et al., Sexual Activity As a Predictor of Life-Span Mortality Risk, 33 Personality \& Individual Differences 409, 422-23 (2002); George Davey Smith et al., Sex and Death: Are They Related? Findings From the Caerphilly Cohort Study, 3I 5 BRIT. MED. J. I64I, I642-43 (I997).

310 See, e.g., David G. Blanchflower \& Andrew J. Oswald, Money, Sex and Happiness: An Empirical Study, IO6 SCANDINAVIAN J. ECON. 393, 4I I (2004).

311 See id. at 402; Adam Crossley \& Darren Langdridge, Perceived Sources of Happiness: A Network Analysis, 6 J. HAPPINESS STUD. I07, I26 (2005); see also Mary H. Burleson et al., In the Mood for Love or Vice Versa? Exploring the Relations Among Sexual Activity, Physical Affection, Affect, and Stress in the Daily Lives of Mid-Aged Women, 36 ARCHIVES SEXUAL BEHAV. 357,36 I, $364(2007)$.

312 See, e.g., Norman J. Johnson et al., Marital Status and Mortality: The National Longitudinal Mortality Study, ro ANNAls EPIDEMiology 224, 236 (2000); Pekka Martikainen et al., Differences in Mortality by Marital Status in Finland from 1976 to 20oo: Analyses of Changes in Marital-Status Distributions, Socio-Demographic and Household Composition, and Cause of Death, 59 Population STUd. 99, II2 (2005); see also Bonnie Burman \& Gayla Margolin, Analysis of the Association Between Marital Relationships and Health Problems: An Interactional Perspective, I I2 PSYCHOL. BULL. 39, 58 (I992) (reviewing the literature to date and finding that being married generally predicts better health outcomes but that no evidence supports a causal relationship).

313 See Yuanreng Hu \& Noreen Goldman, Mortality Differentials by Marital Status: An International Comparison, 27 DEMOGRAPHY 233, 246 (I990).

314 See Ed Diener et al., Similarity of the Relations Between Marital Status and Subjective Well-Being Across Cultures, 3I J. Cross-Cultural PSyCHOL. 4I9, 432 (2000); Steven Stack \& J. Ross Eshleman, Marital Status and Happiness: A I7-Nation Study, 60 J. MARRIAGE \& FAM. 527, 53I, 534 (I998); Kristi Williams, Has the Future of Marriage Arrived? A Contemporary Ex- 
health effects depend on marital quality. ${ }^{315}$ Overall, both sexual activity and marriage appear to have welfare benefits, which those with reduced opportunities in these domains miss. ${ }^{316}$

In addition, it is not just people on the bottom of the hierarchy who are limited by the current regime. Many people's opportunities to meet people from a range of backgrounds and pursue intimate relationships are being limited by a history of exclusionary practices that have shaped our infrastructure and social conditions. Admittedly, it would require a particularly romantic conception of love to argue that specific individuals have not met "the one" for them because the walls of segregation and inaccessibility have kept those particular individuals apart. Such an idea of love is not unheard of, of course; most obviously, Plato's Symposium offered Aristophanes' tale of love as the search for our lost halves, created when the gods split our originary double-beings in half. ${ }^{317}$ But even without a belief that there is just one right person for everyone, we might feel a certain frustration or even outrage to realize that our opportunities to meet people have been constrained by the state's (sometimes intentional) efforts to keep people like us apart. If we think of a current person we love, in whatever capacity, and imagine that the structure of the state had precluded our meeting them because of some aspect of them (or us) that the state did not want mingling, then the limitations on all of us may be felt.

It is of course impossible to determine some optimal amount of mixing. And as to whether there should be more than there is now, with regard to race in particular there are arguments on both sides, in-

amination of Gender, Marriage, and Psychological Well-Being, 44 J. Health \& Soc. BehaV. $470,473,484(2003)$.

315 See, e.g., Janice K. Kiecolt-Glaser \& Tamara L. Newton, Marriage and Health: His and Hers, I 27 PSYCHOL. BULL. 472, 493-94 (200I); see also Williams, supra note 3I4, at 483 (reviewing the literature and observing inconsistent results on the conventional wisdom that marriage per se benefits men more than women and that marital quality affects women more than men, and concluding, from a longitudinal data set, that "[b]eing in a satisfying, supportive marriage offers similar [psychological] benefits to women and men, and exiting such a marriage or being in a strained marriage confers similar costs").

316 Marriage also occupies a certain social status, which those excluded from its domain lack, despite being subject to regulation in its shadow. See, e.g., Ariela R. Dubler, In the Shadow of Marriage: Single Women and the Legal Construction of the Family and the State, I I 2 YALE L.J. I64I (2003). In addition, the state treats unmarried families differently, particularly those families receiving the kinds of state support associated with poverty, who experience a greater degree of state intrusion on their family autonomy. See, e.g., Jill Elaine Hasday, Parenthood Divided: A Legal History of the Bifurcated Law of Parental Relations, 90 GEO. L.J. 299 (2002).

317 Plato, The Symposium 22-26 (M.C. Howatson \& Frisbee C.C. Sheffield eds., M.C. Howatson trans., Cambridge Univ. Press 2008); $c f$. Emens, supra note 146, at 29I-94 (discussing Aristophanes' myth in relation to the cultural fantasy of supermonogamy, the idea of one right person ever). 
cluding from an antisubordination perspective. ${ }^{318}$ I will therefore return to this point, with a different proposal for race than for disability, ${ }^{319}$ but it is worth noting here that the constraints of structural discrimination do not limit the subordinated group members alone.

2. Contributing to the Broader Problem of Discrimination. - Intimate discrimination has effects on discrimination beyond the intimate realm. To begin, the intimate sphere is literally where we make the next generation. Whether we appear in the world through conventional or sophisticated means, most of us grow up in families of origin with adults engaging in horizontal intimate relationships, permanent or temporary. Those relationships may themselves create children of mixed race, which may at least partially unsettle some of the ugliest forms of U.S. white supremacy, based as they are on fantasies of a pure white race untainted by a single drop of nonwhite blood. Evidence that racial hierarchy can arise beyond the particular realm of white supremacy, with fine gradations of color signifying status distinctions, suggests that one should not put too much stock in the expectation that racial mixing will reduce prejudice, however. ${ }^{320}$ More meaningfully, there is reason to think that children of mixed race have more tolerant racial attitudes and prefer racially diverse settings more than do non-mixed race children. ${ }^{321}$

Relatedly, families are at the heart of communities and thus of social and employment networks. Who one knows has significant effects on one's opportunities. Discrimination that prevents and creates both intentional and accidental contacts can have major effects on ongoing social stratification. ${ }^{322}$

\footnotetext{
318 There are also arguments for in-group intimate preferences among disabled people, see supra p. I347, but because the norm with disability has been desexualization (not pairing of particular groups over others), the counter-normative intervention can aim to pair both within and across disability - and therefore not implicate this concern. See infra section IV.D, pp. I390-96 (discussing this contrast).

319 See infra sections IV.D-E, pp. I390-I400.

320 See, e.g., Donna Goldstein, "Interracial" Sex and Racial Democracy in Brazil: Twin Concepts?, io i AM. ANTHRopologist 563, 563 (I999); see also MORAN, supra note 23, at 54-59; supra note $\mathrm{I} 68$.

321 See, e.g., Jean S. Phinney \& Linda L. Alipuria, At the Interface of Cultures: Multiethnic/Multiracial High School and College Students, I36 J. Soc. PsYchol. I39, I5 I-52 (I996); Walter G. Stephan \& Cookie White Stephan, Intermarriage: Effects on Personality, Adjustment, and Intergroup Relations in Two Samples of Students, 53 J. MARRIAGE \& FAM. 24I, 242, 248-49 (I99I). But cf. Diane Barnes, Multiethnic Parentage: A Potentially Valuable Resource in the Quest for Social Cohesion, io J. ETHNIC \& CUltural Diversity IN SOC. WORK 3I, 42-43 (200I).

322 See, e.g., LOURY, supra note 3, at 99-I07; STEPHEN MENENDIAN ET AL., STRUCTURAL RACISM IN THE UNited STATES I3-I6 (2008); DeirdRE A. ROYSTER, RACE AND THE INvisible Hand: How White Networks Exclude Black Men from Blue-Collar JOBS (2003); Note, supra note 56 , at 885.
} 
Apart from effects on the next generation and on third-party connections, the contact created by intimate relations may improve attitudes across race and disability. ${ }^{323}$ Just as, under some conditions, workplace contact among people of different races or abilities improves attitudes across those categories, studies of friendship and race also suggest that interracial friendship positively affects racial attitudes. ${ }^{324}$ And the very limited work on the effects of interracial sexual intimacy also suggests some positive effects on racial attitudes. ${ }^{325}$ An important caveat to this concerns breakups: how relationships play out and eventually end (if they do) could also negatively affect attitudes toward a particular group, though I have found no empirical work on this question. Thus, while the ultimate impact is uncertain and warrants further study, there is some basis for thinking that intimate contact can help ameliorate discrimination.

Moreover, desire and liking are powerful emotions that can transform undesirables into desirables, and thus potentially alter hierarchies. Perhaps this effect is more meaningful for groups that have been cast as undesirable or desexualized, where depictions of sexual desirability - or of coolness - can be transformative in the minds of third parties. For example, the movie Murderball brought to a larger audience the sport of quad rugby and its accompanying glamour and sexuality. ${ }^{326}$ The audience effects of affirmative sexual depictions of sexually stigmatized groups merit careful study. But such depictions are likely to have some significance for individual responses to, as well as broader attitudes toward, stigmatized groups. ${ }^{327}$ Of course, the power of desire and of liking can, as noted above, lead to both negative and positive feelings. But the potential for some impact seems worth taking seriously.

\footnotetext{
323 This hypothesis has been much criticized for overstated claims, but relevant meta-analyses show statistically significant results. See Thomas F. Pettigrew \& Linda R. Tropp, A MetaAnalytic Test of Intergroup Contact Theory, 90 J. PERSONALITy \& SOC. PSYCHOL. 75 I (2006); see also Cynthia L. Estlund, Working Together: The Workplace, Civil Society, and the Law, 89 GEO. L.J. I, 22-29 (2000).

324 See, e.g., Shana Levin, Colette van Laar \& Jim Sidanius, The Effects of Ingroup and Outgroup Friendships on Ethnic Attitudes in College: A Longitudinal Study, 6 GRoup PRocesses \& INTERGROUP REL. 76, 87-88 (2003); Katherine McClelland \& Erika Linnander, The Role of Contact and Information in Racial Attitude Change Among White College Students, 76 SoC. INQUIRY 8I (2006).

325 See, e.g., Shana Levin et al., Interethnic and Interracial Dating in College: A Longitudinal Study, 24 J. SOC. \& PERS. RElationships 323 (2005).

326 See Rosemarie Garland-Thomson, Shape Structures Story: Fresh and Feisty Stories About Disability, I5 NARRATIVE I I3, II5-I6 (2007).

327 Perhaps one way that desire can help to unsettle hierarchies is by inspiring individuals from different communities to listen to each other's stories with compassion. On the power of narrative, imagination, and compassion to aid our appreciation of hierarchies of sex and race, see Martha Nussbaum, Narratives of Hierarchy: Loving v. Virginia and the Literary Imagination, I7 QUINNIPIAC L. REV. 337 (I997).
} 
Finally, as discussed in Part I, the norms of intimate discrimination take on a life of their own outside the intimate sphere, shaping the perceptions of courts in ways that hinder justice for employment discrimination plaintiffs. ${ }^{328}$ And court decisions are just one legal example of the broader set of ways that intimate norms - and particular expressions of those norms - contribute to stereotypes and stigma borne by various groups. ${ }^{329}$ For all these reasons, intimate discrimination creates a set of practical problems with which the state must contend. The next Part discusses how it should do so.

\section{The Roles the State Should Play}

[D]o away with the social and political distinctions now existing, and you immediately turn all the blacks and mulattoes into citizens, co-governors, and acquaintances: and acquaintances... are the raw material from which are manufactured friends, husbands, and wives. The man whom you associate with is next invited to your house, and the man whom you invite to your house is the possible husband of your daughter, whether he be black or white.

\section{- W.W. Wright, Amalgamation (1860) 330}

Those who opposed interpersonal contact between blacks and whites understood the potential consequences. They saw that through such contact the accidents of friendship, sex, and love arise. ${ }^{331}$ And they appreciated the deep significance of such relations to our identity. State actors understood this too, and used that understanding to prevent the commingling of desirables and undesirables. ${ }^{332}$ That regime

328 See supra section I.E, pp. I334-39.

329 See, e.g., Note, supra note 56, at 879-84.

330 W.W. Wright, Amalgamation, 29 DE BoW's REV. I, I4 (I860). The author continues, "If we examine the practical operation of this principle in other countries, we shall find that just in proportion as ... this prejudice of color, if you will, is done away with and abandoned, just in that proportion is the white population of those countries reduced in the standard of civilization and morals." Id. at I 5 .

331 See, e.g., Reginald Oh, Interracial Marriage in the Shadows of Jim Crow: Racial Segregation as a System of Race and Gender Subordination, 39 U.C. DAVIS L. REV. I32 I, I339-4I (2006); Reginald Oh, Regulating White Desire, 2007 WIS. L. REV. 463, 476-85. In addition, civil rights advocates, wise to fears that public associations across race would lead to private relationships across race, devised strategies of desegregation that would minimize such fears. For instance, Thurgood Marshall recounted that the NAACP began its school desegregation efforts with graduate schools, and only later turned to primary schools, to accommodate public fears that integrating young children would have a deeper effect on attitudes toward intimate associations across race. Marshall noted, "Those racial supremacy boys somehow think that little kids of six or seven are going to get funny ideas about sex and marriage just from going to school together, but for some equally funny reason youngsters in law school aren't supposed to feel that way." Alfred H. Kelly, The School Desegregation Case, in QuARrels That HAVE Shaped The ConstituTION 307, 3 I8 (John A. Garraty ed., I987) (internal quotation marks omitted).

332 In this light, we might read an explicit carve-out in federal housing law — the so-called Mrs. Murphy exception for owner-occupied dwellings of no more than five families - as a con- 
has officially ended now, at least with regard to race and to most disabilities, ${ }^{333}$ but it would be naïve to think that the state no longer affects our intimate choices.

Although some important legal mandates have been repealed or struck down, those historical restrictions have arguably helped to shape private preferences and social norms. These norms, in turn, have precluded certain relationships and caused pain and disadvantage for many of those individuals thus separated or desexualized. Moreover, by deciding the form of our communities' institutional and physical infrastructure, the state has shaped who meets whom, who interacts with whom, who has the chance to fall for whom. This occurs, for instance, when the state decides whether to put accessible toilets in a town center and how many. Without accessible toilets, those who require them will not enter or remain in certain public spaces. ${ }^{334}$ There are many institutional examples of the state's shaping which intimate accidents can occur - from the history of redlining and other state influence on residential (racial) segregation; ${ }^{335}$ to the institutionalization of people with mental and physical disabilities; ${ }^{336}$ to school segregation with regard to race and disability (or no school at all for some at some times); ${ }^{337}$ to who sits together (or not) on juries; ${ }^{338}$ to who is housed together in prison spaces. ${ }^{339}$ And we know from the

cession to fears of miscegenation, though it is usually framed in terms of privacy and freedom of association. See 42 U.S.C. $\$ 2000$ a(b)(I) (2000); see also James D. Walsh, Note, Reaching Mrs. Murphy: A Call for Repeal of the Mrs. Murphy Exception to the Fair Housing Act, 34 HARV. C.R.-C.L. L. REV. 605 (I999) (discussing the justifications for the exception and arguing for its repeal). On the role that perceived public fear of miscegenation played in the Supreme Court's choices about which desegregation cases to consider in what order, see infra note 420 .

333 See supra section I.A, pp. I3I5-I8.

334 (Nor will they, probably, be able to have sex in the public toilets.)

335 See, e.g., Sheryll Cashin, The Failures of Integration io-i I, I I5-I7 (2004); IRA KATZNELSON, WHEN AFFIRMATIVE ACTION WAS White i62-66 (2006).

336 See, e.g., Americans with Disabilities Act, 42 U.S.C.A. \$§ I2 Ior(2)-(3) (2000); Olmstead v. L.C., 527 U.S. 58I, 597-60I (I999); City of Cleburne v. Cleburne Living Ctr., Inc., 473 U.S. 432, 462 (I985) (Marshall, J., concurring in the judgment in part and dissenting in part); sources cited supra note 23.

337 On race, see, for example, Brown v. Board of Education, 347 U.S. 483 (I954); and JACK GreEnBERG, CRUSADERS IN THE COURTS (2004), and on disability, for example, the findings of the Individuals with Disabilities Education Act, 20 U.S.C. §§ I400(c)(I)-(2) (2006); and Ruth Colker, The Disability Integration Presumption: Thirty Years Later, I54 U. PA. L. REV. 789, 79496 (2006).

338 See, e.g., Swain v. Alabama, 380 U.S. 202 (1965), overruled by Batson v. Kentucky, 476 U.S. 79 (I986); Norris v. Alabama, 294 U.S. 587 (I935); Strauder v. West Virginia, Ioo U.S. 303 (I879); Mary A. Lynch, The Application of Equal Protection to Prospective Jurors with Disabilities: Will Batson Cover Disability-Based Strikes?, 57 ALB. L. REv. 289, 298-99 (I993); Natasha Azava, Note, Disability-Based Peremptory Challenges: Need for Elimination, 4 CARdozo PuB. L. POL'Y \& ETHICS J. I 2 I, I 2 I-34 (2006).

339 See, e.g., Johnson v. California, 543 U.S. 499 (2005); Lee v. Washington, 390 U.S. 333 (I968) (per curiam); T. Howard Stone, Therapeutic Implications of Incarceration for Persons with Severe Mental Disorders: Searching for Rational Health Policy, 24 AM. J. CRIM. L. 283, 334-34 (I997). 
growing literature in social psychology and decision science that choices are often shaped by subtle influences such as their framing. ${ }^{340}$ Thus, because erotic preferences may be at least somewhat endogenous to these state-sponsored structures, even once the structures are removed, the framing architecture may cast a shadow over our choices. But knowing that the state has created and reinforced intimate discrimination does not tell us whether, or how, the state should be involved in remedying it, and it is to that question that I now turn.

With regard to sex/gender, of course, the state's next step is clear. The state still places express legal restrictions on the sex of one's marital partner, and thus excludes same-sex partners from the benefits, burdens, and expressive significance of marriage. This Part therefore discusses sex more briefly before turning to the terrain of disability and race, where the state's ongoing role is less obvious, because express restrictions are largely a thing of the past. ${ }^{341}$

In the absence of express state-mandated discrimination, state intervention at the individual level - prohibiting or discouraging individuals from discriminating, in the sense of differentiating, in the intimate realm - seems misguided at best, for the reasons discussed in Part II. But the state should nonetheless take affirmative steps to address intimate discrimination, though in different ways for disability and race, in light of the different norms surrounding each. ${ }^{342}$

With disability, the norm is of desexualization, of isolation and exclusion from the intimate realm altogether. In this arena, then, state efforts to lift barriers to entry to intimate relationships are in order. This means improving access to spaces and experiences where relationships begin and develop. It means attending to intimacy in the design of accessibility - what I call the architecture of intimacy. Sex and relationship education, institutional and residential rules, and welfare laws should all be structured to anticipate and facilitate opportunities for intimate relationships. Contrary to the fears of some parents and educators, reducing stigma and building sexual self-esteem

340 See generally Richard H. Thaler \& CASs R. Sunstein, Nudge: ImProving DeCISions About Health, Wealth, ANd Happiness (2008); Ian Ayres, Menus Matter, 73 U. CHI. L. REv. 3 (2006); Colin Camerer et al., Regulation for Conservatives: Behavioral Economics and the Case for "Asymmetric Paternalism," I5 I U. PA. L. REV. I2 I I (2003); Cass R. Sunstein \& Richard H. Thaler, Libertarian Paternalism Is Not an Oxymoron, 70 U. CHI. L. REV. I 59 (2003).

341 Express restrictions are entirely a thing of the past for race and for most disabilities, though they remain robust for mental disabilities, as noted earlier. See supra note 9 and accompanying text; supra notes 20-24 and accompanying text.

342 The question of what sort of action the state should take after it stops requiring discrimination arises in many contexts in addition to intimate discrimination, from school segregation to marital names. See, e.g., Elizabeth F. Emens, Changing Name Changing: Framing Rules and the Future of Marital Names, 74 U. CHI. L. REV. 76I (2007). 
and opportunities should help reduce, not increase, the risk of abusive relationships. ${ }^{343}$

With race, by contrast, the norm is homogamy, or in-group pairing. Here, rather than a norm that excludes an entire group from the intimate domain, the norm pushes people to pair with some rather than others. As discussed in Part II, the race homogamy norm has some proponents among the subordinated group and some sensible arguments on its behalf. ${ }^{344}$ Most notably, members of a subordinated group may well think that strong families composed of subordinated group members are the best way to build self-esteem and resist assimilation to dominant, even racist, cultural influences. For this and other reasons, a state policy that actively encourages opportunities for interracial relationships - even as a response to a history of discouraging such relationships - may be troubling. As I discuss in the final section, in the race context, the state's involvement in intimate discrimination should therefore focus on lifting burdens on existing interracial relationships. To be in an interracial relationship today is still to face numerous obstacles that the state helps to shape to a greater or lesser extent. Particularly in light of the state's history of express restrictions enforcing the homogamy norm, state policies should work to lift burdens on interracial couples.

This Part begins by briefly considering several interventions that the state should likely not pursue. Then it sets out a toolkit of more plausible interventions to address intimate discrimination on a structural level. The rest of the Part uses these tools to detail the best next steps for the state to take with regard to sex, disability, and race.

\section{A. What Not To Do: Preliminary Ideas, Mostly Ill-Advised}

So what are some ways, in theory, that the state might intervene in intimate discrimination in the contexts of race or disability? This section briefly considers several interventions that should not be pursued, including several that are absurd, yet are worth considering to get a handle on the reasons why.

I. The Offense of Marriage Act. - Most intrusively, one could propose a regime in which only mixed race or mixed disability marriages were allowed. (Among so many other objections, we can hear - or see - the protests of deaf Americans, representing the larger point

\footnotetext{
343 See, e.g., Carol A. Howland \& Diana H. Rintala, Dating Behaviors of Women with Physical Disabilities, ig Sexuality \& Disability 4I, 4I (200I) ("Men, and often the women themselves, view women with disabilities as 'damaged goods.' Since they are lucky to get anyone to ask them out on a date, the societal view is that they should be grateful for the attention of any man, even if he is abusive and contributes little or nothing positive to their relationship." (citation omitted)).

344 See supra section II.A.7, pp. I346-47.
} 
about subordinated-group solidarity discussed earlier. ${ }^{345}$ With that in mind, we might cast the state's objection only to all-white, allnondisabled marriages, recognizing that the numbers may not add up perfectly at first. ${ }^{346}$ ) Several years ago, Geoffrey Stone created a similar thought experiment, the Mandatory Miscegenation Act of 2 roo, which provided that "[n]o person who is not genetically certified as a person of mixed race may procreate with another person of the same race." 347 In the fanciful Supreme Court opinion Stone wrote, provocatively upholding the mock statute, the Court noted:

When the Act was first introduced in Congress, its drafters explained the Act as follows: "After centuries of racial strife and division, after endless failed efforts to eliminate racism from our hearts, our minds and our social policies, it is time to bring us all together and to end race once and for all as a divisive social construct.

If all Americans have only one race - the mixed race that is the one true melting pot of America - then and only then will we finally be 'one Nation, indivisible." 348

Nobody, of course, would actually advocate a law that so patently impinges on individual liberty and autonomy. The same could be said of a version of the Act that constrained marriage - not procreation across race and disability. One might suggest instead, however impishly, the Offense of Marriage Act: this statute would permit civil unions for all partners, but decline to grant the label "marriage" to allwhite or all-nondisabled marriages. A system that creates second-class marriages in this way also seems offensive, however, as the Act's name suggests. 349

2. Private Litigation. - Another (misguided) possibility would be to extend our current antidiscrimination regime to the intimate realm: that is, to authorize private lawsuits for sexual or marital rejections that were "because of" race or disability. The problems with this are,

345 See supra section II.A.7, pp. I346-47.

346 It is an interesting question, which I do not take up here, as to which version of the statute - one defining marriage as always between people of different races, or one defining marriage as only nonwhites marrying - would face a bigger constitutional hurdle under Loving v. Virginia, 388 U.S. I ( 1967 ). Both obviously seem very problematic, but while the latter seems more offensive for its segregationist veneer, it also seems more in keeping with the antisubordination strand evident in Loving's appreciation of antimiscegenation laws' link to white supremacy fantasies. $I d$. at I I.

347 Geoffrey R. Stone, Commentary, If America Only Had One Mixed Race, CHI. TRIB., Mar. 30, I999, at I 7 (internal quotation marks omitted) (reprinting Stone's University of Chicago Centennial Contribution).

348 Id.

349 And as the same-sex marriage debates - and discussions of the Defense of Marriage Act have elaborated at great length. 
obviously, legion. ${ }^{350}$ First, there is the problem of a litigation explosion. If there is any truth to Robert Ellickson's observation that "sociopaths and love triangles" are "much overrepresented" in the cases that make it to court, then widely authorizing discrimination-based heartbalm lawsuits would be truly perverse, as it would invite nearly every love triangle into court without even the need for a nexus with an independent legal issue. ${ }^{351}$ We also might worry, as above, about the wisdom of incentivizing personal relationships that individuals may not desire.

Moreover, this approach targets individual decisionmaking on the bad-actor model that haunts our employment discrimination regime and, even if it were the right model there (about which I have doubts ${ }^{352}$ ), it seems distinctly inapt in the intimate domain. As discussed in Part II, animus and intimate discrimination may overlap, but distinctions on these categorical bases may sometimes be necessary for or generative of desire. It is particularly difficult to determine what nondiscrimination would be in this domain, and whether and when it is even desirable. ${ }^{353}$ Even if we could determine what nondiscrimination means, a law targeting individual perpetrators of intimate discrimination would create incentives to hide one's preferences, thus accentuating the difficulty of avoiding those who harbor animus or categorical nondesire towards one's own type. ${ }^{354}$ Moreover, desire, and desire's response to prohibitions, is unpredictable. ${ }^{355}$ Indeed, prohibitions may fuel desire. Whether or not other emotions and attitudes

\footnotetext{
350 These problems are in addition to the questionable constitutionality of such legislation, given Congress's now-limited powers under the Fourteenth Amendment and the Commerce Clause. See, e.g., United States v. Morrison, 529 U.S. 598 (2000); United States v. Lopez, 5 I 4 U.S. 549 (I995). Even the feared (but unrealized) extension of Shelley v. Kraemer, 334 U.S. I (I948), probably could not reach simple dating, though a discriminatory marriage choice is a more interesting question. Doing away with the state action doctrine, as Chemerinsky and a line of others proposed, would open the door to a whole range of such suits; but as Chemerinsky realized even back in 1985 , that is not going to happen. See Erwin Chemerinsky, Rethinking State Action, 80 Nw. U. L. REV. 503, 504-05, 556 (1985). (Chemerinsky also thought that, in the absence of the state action doctrine, courts would directly invoke privacy and associational protections to prevent the law's entanglement with the (nearly proverbial) non-integrated dinner party, the example that is always raised in such conversations. Id. at 538.)

351 Professor Ellickson mentioned this idea in a Property class at Yale Law School in the spring of 200I. See also E-mail from Robert Ellickson to Elizabeth Emens (Nov. 26, 2008, I8:27) (on file with the Harvard Law School Library). Of course, many of these suits would surely not be brought, for a wide variety of reasons. Cf., e.g., Russell K. Robinson, Perceptual Segregation, Io8 COLUM. L. REV. I093, II39-5 I (2008) (discussing costs of publicly alleging discrimination). It is nonetheless interesting to think whether, or how often, love-triangle motivations would overpower the costs of alleging discrimination.

352 See supra note 227.

353 See supra sections II.A-B, pp. I340-57.

354 See supra section II.A.I I, pp. I352-54.

355 Cf. Toni M. Massaro, The Meanings of Shame: Implications for Legal Reform, 3 PSYCHOL. PUB. POL’y \& L. 645, 692-704 (1997).
} 
respond to legal prohibitions as the laws' enactors might have hoped, ${ }^{356}$ desire is surely a realm in which we would not expect prohibitions and exhortations as to individual behavior to lead neatly to the outcomes sought.

3. Tax Benefits. - Less ostentatiously, mixed couples could receive some sort of tax benefit. Such a benefit might seem more apt in the context of groups subject to normative desexualization, rather than normative homogamy, for the reasons discussed above; thus, perhaps this solution is most fitting in the disability context and should apply to all marriages with at least one disabled spouse, whether heterogamous or homogamous (with regard to disability). ${ }^{357}$ But a tax benefit in this area seems problematic for several reasons. First, tax benefits for people subject to systematic disadvantage should not depend on whether those people marry; this seems a troubling distributive principle, even if one favored the incentives it created. ${ }^{358}$ Second, such a tax benefit would send a stigmatizing message about the status and desirability of disabled people - to say that marrying "one of them" warrants some kind of special state financial gift. This is akin to a point made by Tom Shakespeare and others about state subsidies for sex surrogates for disabled people: such initiatives may benefit some individual people with disabilities, but they also send a troubling message about the sexual desirability of disabled people and the potential for true integration. ${ }^{359}$ Finally, one might also worry about creating financial incentives to marry some people rather than others, for fear that there are at least some number of people who might marry for that reason alone, which could be bad for the public fisc, the marrying individuals, or both.

\section{B. Toolkit: A Range of Plausible Structural Interventions}

This section sets out a range of structural interventions that may be useful to address intimate discrimination. These tools are structural in the sense that they do not intend to restrict or burden individual

356 On the particular issue of perverse responses to law, it may be worth thinking more, for instance, about whether the individual bad-actor model in Title VII fuels the anti-"PC" sentiment behind jokes like the one from Maxim magazine discussed in Part I. See also supra note 92 (quoting some of the other jokes in that issue of Maxim, involving racist humor).

357 This would be akin to the federal tax credit provided for the adoption expenses of parents who adopt hard-to-place children, a category that includes children with disabilities. See 26 U.S.C. $§ 23(\mathrm{a})(3)(2006)$.

358 Cf. Linda C. MCClain, The Place of Families i i 7-54 (2006) (discussing governmental marriage promotion initiatives and critiquing the use of marriage as "the sole proxy for family forms that foster adult and child well-being," id. at I54); Shari Motro, A New "I Do": Towards a Marriage-Neutral Income Tax, 9I IOWA L. REV. I509 (2006) (discussing, and arguing against, the "marriage bonus" effectively given under current federal tax rules to many single-earner and unequal-earner married couples).

359 See Shakespeare, Gillespie-Sells \& Davies, supra note 73, at I32-34. 
choices; rather, they aim to allow individual choice and to create the structural conditions for relationships to form or flourish. Subsequent sections discuss which interventions are most appropriate and important for each category, depending on the particular norm and context of that category. Detailed discussion of these tools will be included in these more concrete contexts, but this section first lays out broad types of interventions.

The list, though certainly not exhaustive, should help us to think through the categories at issue in this Article, as well as provide tools for future thinking about intimate discrimination with regard to other groups. As noted earlier, there are many categories that might make for interesting and productive analysis, including age, religion, and class, to name a few. ${ }^{360}$ One's assessment of the problem (if any) of intimate discrimination for a particular identity category should help determine which of the following tools are more or less useful and appropriate, and may open one's eyes to additional tools worth considering.

I. Lifting Formal Restrictions. - A basic step is to remove explicit restrictions - whether criminal or civil - on who can have sex or marry. ${ }^{361}$

2. Eliminating Penalties. - Current laws about state benefits such as welfare benefits - may penalize particular types of relationships, intentionally or effectively, or may discourage the formation or formalization of intimate relationships by those in the relevant groups. ${ }^{362}$ In some circumstances, removing these penalties may be desirable.

3. Leveling the Playing Field. - Having less access to social and material capital — such as housing, education, or employment - can harm an individual's prospects in dating markets. ${ }^{363}$ In some contexts, the state may therefore want to take steps to increase a group's access to social and material capital in order to level the playing (dating) field for individuals in that group. In other contexts, however, although promoting equal opportunity may be good policy for other reasons, it should not be endorsed specifically to promote particular forms of intimate relationships, as discussed below in relation to race.

4. Allowing Access and Integration. - Removing obstacles to access - through accommodation, for instance - can affect the possi-

\footnotetext{
360 See supra pp. I3I0, I3I3.

361 See supra section I.A, pp. I3 I5-I8 (discussing the formal legal restrictions that existed, and in some cases continue to exist, in these areas).

362 See, e.g., infra section IV.D.2, pp. I390-9I (discussing policies leading to the loss of some Social Security and Medicaid benefits for disabled people who marry).

363 See supra p. I369 (noting Randall Kennedy's remarks on the significance of these factors for interracial dating).
} 
bilities of intimacy, as shown earlier, and should be promoted. ${ }^{364}$ As with leveling the playing field, however, I do not urge that (otherwise sound) policies of racial integration be promoted in the name of interracial intimacy, as I discuss below. ${ }^{365}$

5. Designing the Architecture of Intimacy. - Getting into buildings is different from getting close. And getting access to the public sphere is different from getting access to the private sphere. Accommodation and integration should be evaluated for the kinds of intimacies, as well as the basic access, that they do and do not permit.

6. State Expression. - Finally, through forms of state-sponsored expression, such as public funding for the arts or a diversity campaign using public service announcements, the state could endorse affirmative visions of relationships that are relatively disparaged. Because state expression sometimes verges on burdening other types of relationships (see the Offense of Marriage Act discussed above ${ }^{366}$ ), using state expression in this way is a strategy to be used sparingly. A related tool - of scrutinizing public expression for subtly disapproving messages - is often useful. ${ }^{367}$

The rest of this Part elaborates on the meaning and uses of these tools through specific examples relevant to the categories at issue. ${ }^{368}$

364 See supra section III.A, pp. I366-73.

365 See infra section IV.E, pp. I396-I 400 (explaining why this Article does not advocate policies that aim to encourage the formation of interracial relationships, as opposed to those - sometimes overlapping - policies whose aim is to unburden existing relationships).

366 See supra section IV.A. I, pp. I382-83.

367 See, e.g., infra section IV.E.3, pp. I399-I400 (noting the occasional persistence of state marriage license applications that prominently ask for the race of the prospective spouses).

368 As noted, the list is not exhaustive. For instance, one difficult question is whether the toolkit of structural interventions should include regulating third parties; in particular, we might wonder about regulating internet dating sites. The design of dating websites does, after all, help to structure the ways that many individuals define themselves and the possibilities they confront and choices they make about potential partners. See supra note 3 I (discussing the popularity of dating websites). But for that very reason, such internet interactions cut rather close to the space I think needs to be carved out for individuals to make choices and to be their own moral evaluators rather than being judged by government or society. See supra section II.B, pp. I356-57. An example demonstrates the difficulties here: My intuition is that there is a distinction between state interference in a site's utterly excluding some groups from participation in the site — for instance, a court's finding illegal discrimination in eHarmony's excluding same-sex searching, or, if it existed, in a site's excluding all disabled participants (eugenicdating.com, it might be called) - and state control of the types of searches that can be performed. Cf. supra note I I3 (discussing the eHarmony cases). But even this suggestion is problematic, as the current structure of antidiscrimination law in many domains is antidifferentiation, such that a legal decision in the eHarmony case could perhaps be used later to rule, for instance, that lesbians could not have their own dating sites that exclude men. The antisubordination arguments I have discussed, on behalf of self-sorting by subordinated groups, would urge against the state intervening in the lesbian site, but courts might nonetheless allow such intervention after a favorable decision in the eHarmony context. Moreover, state restrictions on the types of search mechanisms may sometimes make sense, particularly where these sites are fora for commercial, rather than merely dating, relationships. Cf. supra note II3 (describing a case involving roommates.com). At any rate, I have not 
The discussion begins with the categories subject to the greatest persistence of formal restrictions and penalties — sex and disability — and then turns to race.

\section{Sex: Lifting Explicit Restrictions and Eliminating Penalties}

With sex, the state explicitly burdens gay and bisexual individuals by restricting marriage to different-sex couples. As has been eloquently stated in many places, the freedom to marry is not an abstract right; for it to mean anything at all, it must mean the freedom to marry the person that you love. ${ }^{369}$ Marriage restrictions have both expressive and practical significance; indeed, their consequences appear innumerable, until one reads the enumerations put together by advocates and even courts. ${ }^{370}$ Related burdens on same-sex couples abound, from the federal Defense of Marriage Act ${ }^{371}$ (DOMA) and state mini-DOMAs and associated tax consequences, to the military's "don't ask, don't tell" policy that prevents gay servicemembers from having open relationships, to the lack of second-parent adoption and restrictions on adoption by gay individuals in many jurisdictions. ${ }^{372}$ To stop enacting intimate discrimination with regard to sex, the state should begin by removing sex-based restrictions on who can marry whom and associated penalties and burdens. ${ }^{373}$

fully developed the relation between my conception of the state as it relates to intimate discrimination and the structure of the internet as a domain of human relationship; this question is beyond the scope of this Article, but I hope to revisit it in future work.

369 See, e.g., Goodridge v. Dep't of Pub. Health, 798 N.E.2d 94I, 958 (Mass. 2003); R.A. Lenhardt, Beyond Analogy: Perez v. Sharp, Antimiscegenation Law, and the Fight for Same-Sex Marriage, 96 CAL. L. REv. 839, 844-45 (2008); cf. Patricia A. Cain, Imagine There's No Marriage, i6 QuinNiPIAC L. REV. 27, 43-44 (I996); Cass R. Sunstein, The Right to Marry, 26 CARdozo L. REV. 208I, 2098-99 (2005).

370 See, e.g., Goodridge, 798 N.E.2d at $955^{-56}$ (providing a list of the benefits denied to some by such restrictions).

371 Pub. L. No. I04-199, I Io Stat. 24 I9 (I996) (codified in scattered sections of I and 28 U.S.C.).

372 See generally AYRES \& BROWN, supra note I2 (describing burdens and proposing innovative public and private responses). For discussion of interpretive and constitutional problems with the mini-DOMAs, see generally Andrew Koppelman, The Difference the Mini-DOMAs Make, 38 LOY. U. CHI. L.J. 265 (2007). Sex-based burdens also include zoning and police practices that target gay bars and bathhouses. See, e.g., WARNER, supra note 98, at I49-93.

373 The same-sex marriage debate has prompted many related debates, including discussion about the value of the institution of marriage, and the rightness of the state's involvement in marriage. See generally Just MARRIAGE (Mary Lyndon Shanley ed., 2004). There is much more to be said on this subject, but so long as the state provides civil marriage to different-sex couples, it should provide it to same-sex couples. Mary Anne Case has also argued that opening marriage to same-sex couples will facilitate some progress toward gender equity in different-sex marriage. See Mary Anne Case, What Stake Do Heterosexual Women Have in the Same-Sex Marriage/Domestic Partnership/Civil Union Debates (Feb. 2004) (unpublished manuscript, on file with the Harvard Law School Library). Whether the state can and should do anything to target gender discrimination in dating, as against feminine men or masculine women, or even against women who are highly educated or successful, see supra p. I334, is an interesting question that deserves further 
It is instructive to see how easy it is to identify what legal changes need to occur in this area, and yet how difficult it is to imagine what comes after those changes. Our intimate decisions with regard to the sex of our partners are limited - through the marriage restrictions, inter alia, mentioned above - in ways that our decisions about race and disability generally are not. ${ }^{374}$ Identifying the immediate steps for the state to take with regard to sex is therefore easy. Trying to imagine what will come next is harder. For instance, think of the Offense of Marriage Act discussed in the previous section. ${ }^{375}$ Such an act regulating relationships based on race or disability may seem troubling or offensive, but a similar act regulating relationships based on sex would be simply preposterous. It seems inconceivable that the state would try to encourage counter-normative pairings by applying the label "marriage" only to same-sex relationships and providing "civil unions" to different-sex couples. This in part reflects the entrenchment of our current legal and cultural regime. But it also reflects assumptions about the relative fixity of sex as a determinant category of desire. ${ }^{376}$ Imagining a legal structure that would incentivize same-sex relations seems absurd, because our usual assumptions do not admit of that degree of flexibility in choices about the sex of our sexual partners, despite studies showing the frequency of some degrees of bisexual desire. $^{377}$ This is a striking difference from the common understandings of race and disability in relation to desire. I do not mean to overstate the imaginative leap beyond removing express legal limitations; for starters, the passage of federal employment-discrimination protection and hate crime laws would lift some material and expressive burdens on gay individuals and couples ${ }^{378}$ and will likely precede marriage reform. But it is nonetheless interesting to note the position of sexual orientation, relative to disability and race, in terms of whether and what affirmative steps are conceivable at this moment in time.

discussion. On the issue of what we all can do to support freedom of sexual orientation, see generally AYRES \& BROWN, supra note I 2 .

374 The primary exception to this comparative point is found in the remaining legal restrictions preventing sex and marriage by people with mental disabilities. See supra notes $20-24$ and accompanying text. These restrictions are akin to those pre-Lawrence laws governing same-sex relations.

375 See supra section IV.A.I, pp. I382-83.

376 See supra section II.A, pp. I340-55.

377 See, e.g., Yoshino, Bisexual Erasure, supra note I I I, at 377-88 (citing studies).

378 On the Employment Nondiscrimination Act, see, for example, National Gay and Lesbian Task Force Inc., Employment Non-Discrimination Act 2007 Action Center, http://www. thetaskforce.org/endao $/$ /endao $7 . h$ tml (last visited Feb. 8, 2009); relatedly, on the gay wage gap, see M.V. Lee BadgetT, Money, Myths, AND Change: The Economic Lives of Lesbians AND GAY MEN 20-50 (200I). On the lack of sexual orientation as a category in federal hate crimes law, see infra note 393. 


\section{Disability: Removing Barriers to Entry and Encouraging Intimacy}

For disability, the structure of the legal and social norm has been exclusionary: people with disabilities have been treated as if outside the sexual realm altogether. A wide range of reforms should thus be undertaken to reduce barriers to entry for people with disabilities, utilizing each strategy set out in the toolkit above.

I. Lifting Explicit Restrictions. - The state's explicit role in intimate discrimination is most plainly ongoing with regard to sex and most plainly consigned to history for race. Disability lies somewhere in between, as discussed in Part I. Explicit eugenics-based restrictions on marriage based on physical disability are largely a thing of the past. ${ }^{379}$ But restrictions - even criminal restrictions - on sexual activity and marriage by people with cognitive disabilities continue. ${ }^{380}$ As Deborah Denno has argued, such per se restrictions need to be replaced with contextualized inquiries into competency to consent, grounded in the same considerations always relevant to determinations of consent. ${ }^{381}$ Per se restrictions on sexual activity by and with people with disabilities stigmatize such individuals and permit families and guardians to deny the possibility of sexuality, a mindset that may itself contribute to the risk of abuse. ${ }^{382}$

2. Eliminating Marriage Penalties. - Federal and state disability benefits are structured in ways that penalize the decision to marry. In some circumstances, marriage per se terminates benefits. For instance, marriage terminates the benefits of a disabled adult child of a Social Security beneficiary if the spouse is not also a Social Security beneficiary, a rule the Supreme Court upheld in Califano v. Jobst. ${ }^{383}$ In addition to per se marriage penalties, marriage can also lead to changes in income calculations that cause a termination of benefits. For instance, a disabled individual who receives Supplemental Security Income (SSI) and then marries and lives with a spouse who is not eligible for SSI will have his income calculated as if it includes some of the spouse's income. ${ }^{384}$ This increase in presumed income - "deemed" to the SSI-eligible spouse on the assumption that his ineligible spouse will use some of her income to care for his needs ${ }^{385}$ - may bump the dis-

\footnotetext{
379 See supra pp. I316-I 7.

380 See Denno, supra note 9; sources cited supra note 24

381 See Denno, supra note 9 , at $32 \mathrm{I}$. For a fuller discussion, see $i d$. at 355-79; and FIELD \& SANCHEZ, supra note 9.

382 Cf. Howland \& Rintala, supra note 343 , at 4I.

383434 U.S. 47 (I 977$)$; see also 42 U.S.C. $\$ \S 402$ (d)(I)(B)(ii), 402(d)(5) (2000). For a discussion of the federal marriage penalties, see Robert E. Rains, Disability and Family Relationships: Marriage Penalties and Support Anomalies, 22 GA. ST. U. L. REV. 56I, 562-74 (2006).

384 See 20 C.F.R. § 4I6.I I60(a)(I) (2005); see also Rains, supra note 383 , at 568-70.

38520 C.F.R. § 4I6.II $60(a)(\mathrm{I})$.
} 
abled beneficiary out of SSI eligibility. Moreover, Medicaid programs in some states are administered in a way that effectively reduces or eliminates a disabled person's benefits upon marriage. ${ }^{386}$ Such benefits - including personal care assistance for people with significant disabilities - are particularly important because they may enable independent rather than institutional living. In addition, these benefits may be available only through public insurance because private insurance often declines to cover tasks put under the category of "personal assistance," though they may be vital to health as well as independence. ${ }^{387}$ A Medicaid system that ceases personal assistance when a disabled person marries effectively assumes that the spouse will take over these tasks. Although a spouse may be willing and able to help with these activities, depending on size, strength, and time, he or she may also be daunted by the prospect of a marriage in which the state assigns to him or her such duties.

3. Leveling the Playing Field. - The relative poverty and unemployment of disabled people is, for the reasons Randall Kennedy has identified in the race context, a serious hindrance in the dating market. ${ }^{388}$ People without the income or status and social connections attendant to employment or education lack key resources for the leisure activities of dating; they may also find confidence harder to come by. In addition, while love may involve accidents and magic, the positive assortative mating patterns - showing that people tend to pair with others who are highly similar on many dimensions including income, education, and attractiveness - indicate that one's social status largely determines one's dating prospects. ${ }^{389}$ Decisions of law and policy, for instance, about which laws to enforce and how vigorously, seem remote from the intimate sphere, but may have significant effects. In addition, for some disabled people who have been denied basic sex education or early experiences with dating, it may be necessary to develop confidence and relevant social skills, as well as to gain ac-

386 See, e.g., Stacy Forster, Disability Rule Change Sought: Marrying Can Lead to Loss of Vital Medicaid Coverage, MilwaukeE J. Sentinel, Jan. 2, 2008, at iB.

387 An example of the overlap is checking patients with spinal cord injuries for pressure sores in the course of assisting with personal hygiene and grooming tasks. See, e.g., K.S. LAWRENCE, The Research and Training Center on IndePendent living, Pressure Sores 7 (2006), http://rtcil.org/products/RTCIL\%2opublications/Health\%20Pressures\%2osores.pdf.

388 See supra p. I369.

389 See supra notes $286-89$ and accompanying text. Complexities arise here, for instance, in the fact that greater education for straight disabled women could possibly be a liability in the dating market in some instances, if men are relatively less educated, $c f$. Fisman et al., supra note i I8, at 685 , or if men seek a stereotype of dependency or docility in a disabled woman, see supra note I63. Though these difficult subjects deserve far more discussion, it is fair to say that improving dating prospects should not trump improving access to other valuable resources such as education. 
curate information about sexual relationships. ${ }^{390}$ Such programming may be particularly important for people with cognitive or psychiatric disabilities and is already provided in some local jurisdictions. ${ }^{391}$ Thus, reforms should promote the enforcement of existing antidiscrimination laws and the creation of new policies to support employment and independence ${ }^{392}$ - both of which have additional arguments in their favor - and they should expand psychological programming and support groups that specifically address dating and intimate relationships. Finally, hate crimes can affect the day-to-day experience of people with disabilities, as well as those who travel with them. Although some local jurisdictions have hate crimes laws that cover disability, most do not, and legislation to create federal hate crime protection for disability (among other categories) has been proposed but not yet enacted. ${ }^{393}$

4. Basic Accessibility. - As portrayed through the I-City and ACity hypotheticals in Part III, the accessibility of the local community affects not only people with disabilities, but also those who are close to them. Whether the range of public accommodations - such as restaurants, hotels, and theaters - meets ADA standards of accessibility determines whether disabled people and their partners can enter them. Though many of these changes are already required by law, ${ }^{394}$ enforcement of Title III has been inadequate, as it depends largely upon private lawsuits (for which damages are unavailable) that have often been met with hostility by the courts. ${ }^{395}$ Public transportation must be accessible and also reasonably efficient, and accessible private trans-

390 For a list of some resources and curricula for sex education in the context of disability, see, for example, Dimple Keshav \& BARbARA HubERMAN, SEX EduCATION For PHySiCALLY, Emotionally, AND Mentally Challenged YouTH 4-5 (2006), http://www. advocatesforyouth.org/PUBLICATIONS/frtp/challengedyouth.pdf.

391 For instance, the New York City neighborhood of Chelsea is home to a state-financed social club called the Lonely Hearts Club for people with severe mental illness. The club operates as part "how to find a date" assistance and part discussion group involving "deeper meditations on the nature of relationships, how to find them, manage them and survive them, when merely moving through daily life can be treacherous enough." Sarah Kershaw, Fragile Matters of the Heart, N.Y. Times, Feb. Io, 2008, at $\mathrm{CY}_{5}$.

392 For examples of such policies, and arguments in their favor, see, for example, Bagenstos, supra note 307 ; see also infra section IV.D.4, pp. I392-93.

393 On the status of the Local Law Enforcement Hate Crimes Prevention Act, which would cover disability, race, gender, and sexual orientation, inter alia, see, for example, Human Rights Campaign, The Local Law Enforcement Hate Crimes Prevention Act/Matthew Shepard Act, http://www.hrc.org/fighthatecrimes/legislation.html (last visited Feb. 8, 2009). Local hate crimes laws covering disability include that of New Jersey, which has also led to a high-profile prosecution. See, e.g., Mark Sherry, Hate Crimes Against People with Disabilities (Jan. 20oo) (unpublished paper, University of Queensland), available at http://www.wwda.org.au/hate.htm.

394 See Americans with Disabilities Act, 42 U.S.C. § I 2 I82 (2000); 28 C.F.R. §§ 36.IoI-.IO4 (2008).

395 See, e.g., Samuel R. Bagenstos, The Perversity of Limited Civil Rights Remedies: The Case of “Abusive” ADA Litigation, 54 UCLA L. REV. I, 4-5 (2006). 
portation, such as taxis and airport shuttles, is crucial to enabling dating and other intimate relationships. ${ }^{396}$ Accessibility is important across domains of life, from housing to employment to education to health care to public spaces to government buildings, both for the individuals with disabilities who require it and for those who accompany them, disabled or nondisabled. For starters, if the courthouse is not accessible, it is hard to get married in it. ${ }^{397}$

5. The Architecture of Intimacy. - Viewing these proposed changes through an intimacy lens also forces us to consider the way we integrate. Does the structure of integration merely allow everyone to be in the same building, or does it permit or even encourage any kind of closeness? For example, it is useful for restaurants to provide ramps and wide enough aisles for patrons in wheelchairs to enter the space; that is progress. And the ADA requires that public accommodations not segregate disabled patrons into separate eating areas. ${ }^{398}$ But intimacy requires more. The design of tables determines whether those patrons who come with their own chairs can sit near to others at the table. For instance, if tables are too short, or are supported by legs with a wide base, wheelchairs cannot pull fully up to the table, leaving diners at an awkward and impersonal distance. This is one very specific example of a broader inquiry into what we might call the architecture of intimacy.

Other examples of the architecture of intimacy are potentially as varied as disabilities. For instance, both cross- and within-disability intimacy could be enhanced by wider availability of instruction in sign language. Communicating directly with another, rather than through an interpreter, allows for a different kind of fluidity and proximity. ${ }^{399}$ State universities could increase fluency in American Sign Language (ASL) by permitting students to count ASL courses towards language requirements, as a limited number of universities currently do. ${ }^{400}$

396 See SHAKespeARE, Gillespie-SElls \& DAVIES, supra note 73, at 29-30; Rembis, supra note 79, at 4-5; Dikaios Sakellariou, If Not the Disability, Then What? Barriers to Reclaiming Sexuality Following Spinal Cord Injury, 24 SExuAlity \& DiSABILITy ıо , Iо7 (2006); cf. Howland \& Rintala, supra note 343 , at 55-56.

397 Cf. Tennessee v. Lane, 54 I U.S. 509, 532-34 (2004).

39828 C.F.R. ch. I, pt. 36 , app. A, § 5.4 (I 994$)$.

399 Of course, indirect contact can also involve its own particular forms of intimacy; think here of email, among other media. See, e.g., Jerry Kang, Cyber-Race, I I3 HARV. L. REV. II 30 , II50 (2000). But the option of employing either direct or indirect communication would seem to expand the possibilities. In addition, in the context of sign language, communicating with an interpreter also allows intimacy with an interpreter, but more people knowing sign language might also lead to more frequent employment of interpreters for lectures and other events.

400 See, e.g., Indiana University, Degree Requirements, http://www.indiana.edu/ bulletin/iub/ coas/2006-2008/degree.shtml (last visited Feb. 8, 2009) (citing Indiana University's policy to this effect); The University of Chicago, Language Competence Requirement, http://www. college.uchicago.edu/academics/language.shtml (last visited Feb. 8, 2009) (same). But see, e.g., 
Wider availability of services in movie theaters that provide audio descriptions of what is onscreen would not only enable solo blind moviegoers, but would also allow blind moviegoers to go to the movies together, and allow blind and sighted moviegoers to watch a movie without the sighted watcher distracting himself and others by describing the movie to his blind companion as it goes along. ${ }^{401}$ (Of course, if the descriptions are sufficiently elegant and well-timed, then sighted moviegoers might benefit from them as well, further enhancing the mutuality of the experience..$^{402}$ )

In addition to making intimacy more possible in accessible spaces, the architecture of intimacy includes making intimate spaces more accessible. For instance, there could be public support or regulation to make private homes accessible - what has come to be known as "visitability." 403 Intimate affiliations are deeply affected by who can enter another's home. ${ }^{404}$ The visitability movement therefore promotes home construction that enables people who use walkers or wheelchairs, or otherwise have trouble with steps, to visit or to live in those homes. ${ }^{405}$ Visitability has three basic requirements: one entrance with no steps, doorways at least thirty-two inches wide, and one main floor bathroom that someone in a wheelchair can enter. ${ }^{406}$ Though the

UCLA, UCLA General Catalog 2008-09, http://www.registrar.ucla.edu/catalog/catalogo8-o94I.htm (last visited Feb. 8, 2009) (indicating that UCLA's foreign language requirement does not count ASL); CU Sign, CU Sign's New Initiative, http://www.columbia.edu/cu/sign/ new_initiative.html (last visited Feb. 8, 2009) (stating that Columbia University does not currently permit ASL to satisfy the language requirement).

401 The arrangement of seats in movie theaters, and other performance spaces, provides another example: seating should be arranged so that those requiring accommodations, such as those in wheelchairs who require space without seats, can be spread out in the theater, sitting among companions who are not in wheelchairs, or gathered together, sitting among companions who are also in wheelchairs.

$402 C f$. Emens, supra note 259 , at 9I 7 n.223; id. passim (discussing the third-party benefits of many accommodations, depending on how they are designed, including an example of different film descriptions that either interfered with or enhanced the experience for all).

403 See, e.g., Visitability, http://www.visitability.org (last visited Feb. 8, 2009); accord JORDANA L. Maisel et Al., InCReAsing Home ACCess: Designing For Visitability (2008), available at $\mathrm{http}: / /$ assets.aarp.org/rgcenter/il/2008_I4_access.pdf.

404 Cf. supra pp. I370-7 I (portraying the role of visitability in the ease of the dating scenarios in the two hypotheticals).

405 The visitability movement targets new housing not covered by existing laws that mandate more stringent measures of accessibility, especially new single-family homes. See MAISEL ET AL., supra note 403, at 9. The Architectural Barriers Act of I968, 42 U.S.C. \$\$ 4I5I-4I57 (2000), and the Rehabilitation Act of I973, Pub. L. No. 93-I I2, 87 Stat. 355 (codified as amended in scattered sections of 29 U.S.C.), require five percent of the housing constructed using public funds to have accessible units. The Fair Housing Amendments Act of 1988, 42 U.S.C. $\$ 360$ I note (2000), requires all new multifamily dwellings, public and private, to be accessible. The standards for accessibility are more extensive than those for visitability. MAISEL ET AL., supra note 403, at 6-8.

406 See Maisel et Al., supra note 403, at 9; Rehabilitation ENGiNEering ReSEARCH Center on Universal Design, Visitability i, http://www.ap.buffalo.edu/idea/ visitability/Booklet/VisBk\%20Ver3-7-03.pdf; Visitability, http://www.visitability.org (last visited 
movement is still in its early stages, a number of jurisdictions have passed visitability initiatives, often through advocacy efforts focused on both aging and disability; as of December 2007 , fifty-seven such initiatives had been passed at the state or local level. ${ }^{407}$ Some of these are mandatory for all new homes, ${ }^{408}$ including one in Pima County, Arizona, that survived a state constitutional challenge brought by aggrieved builders under the privacy and equal protection provisions of the state constitution. 409

Visitability can also be promoted through tax credits and requirements for public housing contracts. ${ }^{410}$ For instance, Virginia provides a tax credit of up to $\$ 500$ for making private homes visitable (and, in an unusual move, uses the word "visitability" in the statute). ${ }^{411}$ Georgia restricts contracts for new public housing to applications that meet some visitability requirements, unless such construction will be "unreasonably expensive," a type of cost-cap measure common to these initiatives. ${ }^{412}$ Most of the current visitability legislation concerns new construction, rather than retrofitting (which is sometimes costly), though Virginia provides its tax credit for either retrofitting or new construction. ${ }^{413}$ These initiatives often conform to only one or two, but not all three, requirements of visitability. ${ }^{414}$ A bill introduced in Congress in 2002 (and again in 2003, 2005, and 2007) - the Inclusive Home Design Act ${ }^{415}$ — would require all new single-family homes constructed with federal financial assistance to meet all three visitability require-

Feb. 8, 2009). The bathroom can be a "half bath," that is, with only a toilet and a sink. MAISEL ET AL., supra note 403 , at I.

407 See MAISEL ET AL., supra note 403 , at 2 I.

408 See, e.g., id. at I2; Jodi Wilgoren, Wheelchair Users Achieve Milestone in 2 Ordinances, N.Y. Times, Feb. 7, 2002, at A20; RERC on Universal Design at Buffalo, http://www. ap.buffalo.edu/idea/visitability/reports/existingcitylaws.htm (last visited Feb. 8, 2009).

409 Washburn v. Pima County, 8I P.3d ro30, ro39-40 (Ariz. Ct. App. 2003) (noting that the cost of compliance is likely to be $\$$ Ioo (presumably per home), "substantially less" than the cost of later retrofitting, and less than the $\$ 200$ cost cap, above which the county may waive the requirement). The Arizona Supreme Court denied review. See MAISEl ET AL., supra note 403, at 66.

410 A recent study estimates, however, that the mandatory initiatives have led to far more visitable houses being built. MAISEL ET AL., supra note 403, at $2 \mathrm{I}-22$.

411 See VA. CODE ANN. § 58.I-339.7 (2004).

412 GA. CODE ANN. $\S 8-3-\mathrm{I} 72$ (2004). Michigan law requires, as of 2007 , that $50 \%$ of new family construction that receives state funding will be accessible. МICH. COMP. LAWS § I 25.28 I 3 (2007). The Michigan law, like many of these regulations, speaks just of accessibility, without any particular attention to visitability. Requirements that enable disabled people to live in, and not just visit, newly constructed homes are of course most valuable, beyond the idea of visitability.

413 VA. CODE ANN. § 58.1-339.7.

414 See, e.g., 20 VT. STAT. ANN. tit. 20, § 2907 (2005) (imposing requirements on new construction - other than by the owner - but failing to mention the width of bathroom entrances).

415 H.R. 4202, I Ioth Cong. (2007); H.R. I44I, Iogth Cong. (2005); H.R. 2353, I08th Cong. (2003); H.R. 5683, I07th Cong. (2002). 
ments. ${ }^{416}$ Promoting visitability's requirements, whether through regulation or subsidy, could vastly alter the potential for various forms of intimacy for people with mobility impairments. ${ }^{417}$ Both forms of the architecture of intimacy — making accessible spaces intimate and making intimate spaces accessible - are important reforms to counter the norm of desexualization for people with disabilities.

6. State Expression. - Important work in the arts and popular culture has helped to encourage recognition of the diverse sexualities of disabled people and challenge the myth of desexualization. Much work remains to be done, however, and funding is scarce. Arts funding, as one example of state expression, could help to counter stigmatizing and misleading norms in this area.

\section{E. Race: Unburdening Existing Relationships}

Those lawmakers and bureaucrats who have overseen the incomplete project of desegregation have been well aware of the homogamy norm and, more pointedly, of fears of miscegenation. As the author of this Part's epigraph warned in I860, "Do[ing] away with the social and political distinctions now existing ... [will] turn all blacks and mulattoes into citizens, co-governors, and acquaintances ... [and thus into] friends, husbands, and wives." 418 This history should be an additional reason we look closely at social patterns that we claim are now just free choice; if we still are not comfortable with interracial relationships, then we may still be making policy that, on some level, reflects those fears.

I. The Best Policy for Race. - Structural subordination on the basis of race has received much attention for its material consequences. ${ }^{419}$ The intimate consequences should concern us here as well. Given that the historical progress of desegregation was haunted by fears of miscegenation, ${ }^{420}$ we might expect lingering fears in this area

416 See MAISEL ET AL., supra note 403, at 7 (discussing H.R. 4202, (re)introduced by Rep. Jan Schakowsky (D-Ill.) on November I5, 2007).

417 In addition, all of the work I have seen on visitability focuses, somewhat surprisingly, only on facilitating wheelchair access, without regard to other kinds of disabilities.

418 See supra p. I379 (emphasis omitted).

419 See, e.g., CASHIN, supra note 335 , at xix ("[U]nless and until we complete the unfinished business of the civil rights movement, meaningfully integrating our public and private realms in a way that gives all Americans, especially those who have been most marginalized, real choices and opportunities, we will not solve the conundrum of race and class inequality in America."); MENENDIAN ET AL., supra note 322 , at 9 ("[A] combination of public and private racial discrimination has produced entrenched patterns of residential segregation and resources disparities that exist today.").

420 See, e.g., Michael Klarman, An Interpretive History of Modern Equal Protection, 90 MICH. L. REV. 2 I3, 243 (I99I) (discussing the Court's evasion of the antimiscegenation law case of Naim v. Naim for fear that it could "thwart[] or seriously handicap[] the enforcement of [our] decision in the segregation cases," as Justice Frankfurter put it to the Court in a memorandum read at con- 
to continue to limit the possibilities for racial justice. Until we are able to talk about intimate discrimination, in its richness and complexity, as well as its link to the bleaker side of race relations, we may not be able to talk effectively about housing and schools and a range of other, more apparently material, domains. We should therefore think carefully about the ways the state structures who meets whom, and what influences the decisions of law and policy that determine those structures.

We might go further. We might say that the state should be concerned about the low rates of interracial marriage, in light of the state's formal and informal contribution to preferences and choices that must in part be endogenous to the institutional and legal regimes of the society. Perhaps the state's involvement in who meets whom, and who comes close to whom, should be the focus of explicit, targeted intervention. Perhaps intimate discrimination should be offered as the reason for the structural interventions that others have been arguing are needed for a range of social and economic reasons, and maybe we should take further affirmative steps in the name of intimate integration. ${ }^{421}$ Or perhaps the state should engage in affirmative expression - through stamps or public art - to encourage interracial relationships. The idea of promoting interracial relationships to counteract the past is an interesting idea, but one that I think goes too far, for the reasons that follow.

To center state policy on the goal of encouraging interracial relationships - even if intended as a remedial effort in response to a history of explicit state efforts to prevent such relationships - would not only run into possible constitutional difficulties, it would probably be the wrong policy decision, for two reasons. First, reasonable minds can disagree about whether intimate differentiation - at the individual level - is bad, neutral, or even good. As discussed in Part II, some people, especially members of subordinated groups, may wish to pair inside their community, to resist assimilation and form supportive intimate communities. In addition, any number of reasons might frame people's choice of mate, political or otherwise, and so for the state to try to encourage individuals in one direction or another seems hard to justify. ${ }^{422}$ One might ask why disability warrants more explicit interventions targeting the formation of relationships. Different

ference on Nov. 4, I955 (internal quotation marks omitted)); see also Dennis J. Hutchinson, Unanimity and Desegregation: Decisionmaking in the Supreme Court, 1948-1958, 68 GEO. L.J. I, 9596 (1979) (reprinting the memorandum).

421 I read Rachel Moran to advise this approach, recommending "[z]oning policy, home loan programs, integration of schools, and affirmative action in workplaces" to "expand the range of options that individuals can consider." MORAN, supra note 23 , at I94.

422 See supra Part II, pp. I339-66. 
treatment is justified because the norm with disability is one of isolation and exclusion - not pressure toward one group rather than another $^{423}$ - so efforts to encourage intimate possibilities for disabled people lack a counterclaimant. ${ }^{424}$ Remember that the efforts in the disability arena do not aim to encourage cross-ability relationships in particular; rather, they aim to support possibilities for disabled people to pair together or to pair with others without disabilities. Second, and simply, policies to encourage interracial relationships are likely to rankle, rather than persuade, as they sound like social engineering, possibly against individual or community wishes, in a highly personal realm.

2. What To Do: Lifting Material Burdens by Eliminating Housing Discrimination. - The better approach would aim to lift social burdens on existing interracial relationships. Much of the impact of such an effort would be on the enforcement side; that is, as with some of the disability proposals, relevant law is on the books in several areas, but it is not adequately enforced. ${ }^{425}$ The most obvious such area for race would be in housing. ${ }^{426}$ Housing discrimination is still rampant; indeed, interracial couples likely see more of it and more dramatically, since they are built-in testers. ${ }^{427}$ Studies using pairs of black and white testers continue to reveal substantial amounts of racial steering in the housing market. An administration committed to racial equality, but also one committed to unburdening interracial relationships, would put meaningful resources into enforcing the Fair Housing

423 There are some historical counterexamples, however; for instance, Alexander Graham Bell was an outspoken opponent of deaf people marrying other deaf people, since he so favored assimilation. See, e.g., Douglas C. Baynton et Al., Through Deaf Eyes: A Photographic History OF AN AMERICAN COMMUNITY 7I, 74 (2007). But the broader norm has been one of desexualization and exclusion per se.

424 Of course only consensual relationships are encouraged; as discussed earlier, though fears of abuse may contribute to desexualization, I think we should be more concerned that desexualization compounds the risk of abuse. See supra p. I390.

425 E.g., Holcomb v. Iona Coll., 52 I F.3d I30 (2d Cir. 2008) (discussing Title VII's protections against associational discrimination in employment).

426 Other relevant areas include, for example, education, which may affect the children of interracial couples at the primary and secondary school levels, and may affect young couples at the post-secondary levels. But the prospect of school integration has been made increasingly difficult, particularly outside of elite educational contexts with extensive resources to devote to individualized admissions processes. See, e.g., Parents Involved in Cmty. Sch. v. Seattle Sch. Dist. No. I, I 27 S. Ct. 2738 (2007); Grutter v. Bollinger, 539 U.S. 306 (2003); Gratz v. Bollinger, 539 U.S. 244 (2003); Michelle Adams, Stifling the Potential of Grutter v. Bollinger: Parents Involved in Community Schools v. Seattle School District No. I, 88 B.U. L. REV. 937 (2008); see also LANI Guinier \& Gerald Torres, The Miner's Canary: Enlisting Race, Resisting POWER, TRANSFORMING DEMOCRACY (2002).

427 See, e.g., CASHIN, supra note 335 , at 32-34 \& passim; Cynthia L. Estlund, Working Together: The Workplace, Civil Society, and the Law, 89 GEO. L.J. I, I4-I6 (2000); see also Chito Childs, supra note $\mathrm{I} 69$, at $2772-73$. 
Act. ${ }^{428}$ The housing-related burdens on interracial couples are also broader than specific instances of housing discrimination. Interracial couples bear a particularly heavy burden from the lack of meaningfully integrated neighborhoods, as it makes it nearly impossible for such couples to find communities in which they - and any children they may have - can settle amidst mutual communities of origin. ${ }^{429}$ Preventing discrimination from interfering with individual choices of where to live is the tool described above as allowing access; working to eliminate housing discrimination in ways that lead to integrated neighborhoods that are comfortable spaces for interracial couples sounds also in the architecture of intimacy. ${ }^{430}$

Residential segregation is much more than a function of private preferences; as twentieth-century historians have documented, government agents at all levels determined the patterns of racial distribution and home ownership through practices such as redlining. ${ }^{431} \mathrm{Im}$ portant work is underway to determine the best policy routes to integrating our communities, in the interests of racial and economic justice and in an effort to undo the twentieth-century history of statesponsored housing segregation; 432 lifting the burdens on interracial couples is yet another reason for such efforts. Of course, greater integration may also facilitate new relationships across race. ${ }^{433}$ But the policy justification for them, to the extent that it implicates intimate relationships, should center upon unburdening existing relationships.

3. Lifting Expressive Burdens. - The state's expressive burdens on existing interracial relationships should also be eliminated. As one small but striking example, marriage license applications in various jurisdictions continue to request each party's race, even though this information should no longer have any effect on a couple's ability to marry. ${ }^{434}$ Some jurisdictions request this information in an apologetic way at the bottom of the form, headlined by a note that it is being

428 Fair Housing Act, 42 U.S.C. $\S 360 \mathrm{I}$ (2000).

429 See, e.g., CASHIN, supra note 335 , at $4 \mathrm{I}-43$ (presenting evidence of the scarcity of integrated neighborhoods, under multiple definitions).

430 See supra section IV.B.4-5, pp. I386-87.

431 See, e.g., sources cited supra note 335.

432 See, e.g., CASHIN, supra note 335; MENENDIAN ET AL., supra note 322 ; Powell, supra note 232; Olatunde C.A. Johnson, Dismantling the Segregated State (unpublished manuscript, on file with the Harvard Law School Library).

433 This would be particularly true if one extended the interventions to those structural features of society that indirectly affect interracial relationships - like the ongoing fact of racial animus. Differing experiences and understandings of racism can create a heavy burden for interracial couples. See sources cited supra note 294. Increased interracial contact and public education about racism, to name two examples, would presumably be among the best ways to remove these burdens on communication and mutual understanding, see supra p. I378; these would also likely pave the way for more interracial friendships as well as romantic relationships.

434 See Emens, supra note 342 , at 846-47. 
used only for data collection purposes. But Mobile County, Alabama, for instance, asks for race on the very first line of the application. ${ }^{435}$ This presumably links to a history of various Southern jurisdictions' filing white and black marriages separately. ${ }^{436}$ This kind of framing of individual decisions should stop, due to the signals it sends inside and outside the state's bureaucracy. ${ }^{437}$ But unlike matters incidental to marriage - like the names the parties choose to keep or adopt on marriage, which may be decided by some parties at or after the moment of state filing ${ }^{438}$ - the decision of who to marry is surely already decided by everyone who shows up to complete a marriage license application. Thus, the purpose of altering questions about race on the marriage license application is not to change a decisional frame in order to affect behavior. ${ }^{439}$ This is consistent with the Article's proposal that the state's approach to intimate discrimination in the context of race should be to unburden existing interracial relationships, not to encourage the formation of new ones. Race should be removed from the first line of a marriage license application because its implication is offensive - because of its expressive message - but not because it will change individual choices about intimate discrimination.

\section{CONCLUSION}

Analyzing the problem of intimate discrimination has shown that regulatory intervention is appropriate at the structural, but not the individual, level. Sources from law and psychology, sociology, economics, and literature demonstrate that discrimination at the level of individual preferences and interactions may be troubling, but it may also be affirming or neutral, depending on context and rationale. State involvement with individual intimate preferences would also impede personal autonomy. It would be woefully misguided to regulate individual intimate preferences in the same way that we regulate employ-

435 Mobile County, Alabama, Marriage License Application, available at http://www. mobilecounty.org/probatecourt/frame-marriagelicense.htm.

436 See, e.g., Alabama County Still Files Marriage Records by Race, WASH. Post, July 2I, I99I, at Ai6 ("A century-old custom of recording marriages by race in books marked 'white' and 'colored' is still practiced in rural Chambers County. ... 'The county was organized in 1832 , and it's been handled that way all the time up to today,' said Emerson W. Thompson, probate judge since I983. 'What's wrong with it?"').

437 By contrast to Mobile's approach, the more neutral, even apologetic, framing of questions about race, of the sort mentioned just above, is a more appropriate way to collect data on race that may be useful to public deliberation and antisubordination efforts of various sorts. See, e.g., Amer. Sociological Ass'N, The Importance of Collecting Data AND Doing SoCIAL SCIENTIFIC RESEARCH ON RACE (2003), available at http://www2.asanet.org/media/ asa_race_statement.pdf.

438 See generally Emens, supra note 342.

439 Cf. supra note 340 (citing sources on decision science). 
ment preferences. Nonetheless, self-interrogation about one's intimate preferences could usefully inform ethical choices in this domain. Considering the possibility of such an inquiry has shown us a productive dynamic between law and critical inquiry: applying the legal framework of functionalism proves a useful way to think about intimate discrimination in a personal, ethical sense, and pushing the legal framework through this psychological lens provides fresh insight on the value of the legal framework as an interpretive tool for challenging stereotypes.

Important norms in the intimate domain frame our choices: for race, homogamy; for sex, heterogamy; for disability, desexualization. Society punishes those who violate these norms, but the norms can also harm those who do not violate them, in particular, those people with disabilities who may never have the chance to violate these norms because they are relatively excluded from the dating markets. Moreover, hierarchies in the markets for sex and marriage have significant consequences for welfare - affecting longevity, health, and happiness - and for the problem of discrimination more broadly. Intimate norms also seep into the employment domain, where assumptions from the intimate sphere hinder courts' ability to recognize discrimination where it occurs.

We have also seen how the state shapes the accidents and calculations of sex and love. Even when seemingly uninvolved in intimate discrimination, the state creates infrastructure and influences hierarchies in ways that determine whom we meet (accidents) and how we view those we meet (calculations). And here, unlike in the individual domain, the state should take action. Most obviously, the state should complete the process of removing itself from express restrictions on who can pair with whom in the domain of sex. The state should also work to overcome the desexualization norm for disabled people by, inter alia, not only fulfilling the promise of the ADA to provide adequate accessibility, but also reconsidering accessibility through the novel frame of the architecture of intimacy. The architecture of intimacy encompasses both making accessible spaces intimate and making intimate spaces accessible. The former refers to enabling disabled people to do more than simply enter spaces, by enabling them also to be close to those they might meet, date, and love. The latter refers to the visitability movement, which aims to make new private home construction accessible, at least minimally, so that disabled people can be welcomed into the homes of their friends, their lovers, and the friends and families of those they love.

Moreover, studying intimate discrimination in the context of race reveals the burdens that state policy places on existing interracial relationships, thus highlighting the failures of the project of integration. In particular, residential housing segregation burdens interracial couples by failing to provide interracial communities where they might 
choose to live. Thus, the intimate lens with regard to race largely gives an additional reason for initiatives that seem a good idea otherwise. But it also helps explain why the housing problem has not yet been solved: the assumption that like attracts like joins with lingering fears of miscegenation to impede progress toward integration close to home. In short, if we already know what to do, it may be helpful to understand why we have not done it yet.

Finally, we have seen in the study of intimate discrimination an important reason for moving from the individual level to the structural level in antidiscrimination law. Focusing on the individual level raises a whole host of problems and pitfalls that the structural level avoids. Moreover, focusing on the structural level can open up possibilities for change that are unimaginable at the individual level. It is inconceivable that punishing individuals whose intimate desires do not encompass all races or ability levels or sexes will bring about an appealing outcome at the individual, much less the societal, level. Yet this individual bad-actor model is precisely what underpins the dominant understanding of our current employment discrimination regime. In contrast, structural changes — from embracing the architecture of intimacy to lifting burdens on mixed race couples by helping to support genuinely integrated neighborhoods to changing marriage law to include same-sex couples - might engender larger, more substantive change. Creating opportunities for human flourishing, without unduly burdening individual potential and autonomy, should be the core aims of antidiscrimination efforts. An examination of the intimate domain helps us to see why a move to the structural level is crucial to that effort. 